DOE/AL/62350-222

REV. 1

CONTROLLED COPY

\title{
LONG-TeRm SuRveillance PLAN For THE GUNNISON, COLORADO Disposal SiTE :
}

\author{
RECEIVED \\ AUG $0>1996$ \\ OSTI
}

May 1996

DISTRIBUTION OF THIS DOCUMENT IS UNLIMITED

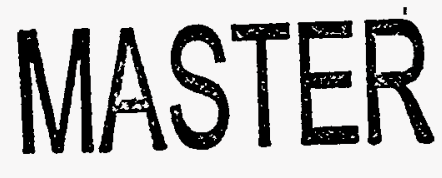


This report has been reproduced from the best available copy. Available in paper copy and microfiche

Number of pages in this report: 68

DOE and DOE contractors can obtain copies of this report from:

Office of Scientific and Technical Information

P.0. Box 62

Oak Ridge, TN 37831

(615) $576-8401$

This report is publicly available from:

National Technical Information Service

Department of Commerce

5285 Port Royal Road

Springfield, VA 22161

(703) $487-4650$ 


\section{DISCLAIMER}

Portions of this document may be illegible in electronic image products. Images are produced from the best available original document. 


\section{DISCLAIMER}

This report was prepared as an account of work sponsored by an agency of the United States Government. Neither the United States Government nor any agency thereof, nor any of their employees, makes any warranty, express or implied, or assumes any legal liability or responsibility for the aceuracy, completeness, or usefulness of any information, apparatus, product, or process disclosed, or represents that its use would not infringe privately owned rights. Reference herein to any specific commercial product, process, or service by trade name, trademark, manufacturer, or otherwise does not necessarily constitute or imply its endorsement, recommendation, or favoring by the United States Government or any agency thereof. The views and opinions of authors expressed herein do not necessarily state or reflect those of the United States Government or any agency thereof. 


\section{LONG-TERM SURVEILLANCE PLAN FOR THE \\ GUNNISON, COLORADO, DISPOSAL SITE}

May 1996

Prepared for

U.S. Department of Energy

Environmental Restoration Division

UMTRA Project Team

Albuquerque, New Mexico

Prepared by

Jacobs Engineering Group Inc.

Albuquerque, New Mexico 


\section{TABLE OF CONTENTS}

Section

1.0 PURPOSE AND SCOPE

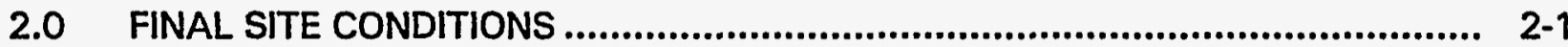

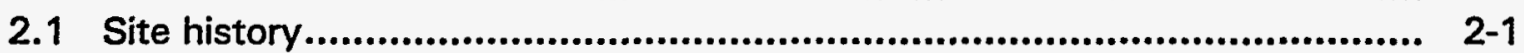

2.2 General description of the site vicinity ............................................... $2-2$

2.3 Disposal site description ....................................................................... 2-4

2.3.1 Site ownership and legal description ............................................ 2-5

2.3.2 Directions to the disposal site .................................................... 2-5

2.3.3 Description of surface conditions................................................. 2-5

2.3.4 Permanent site-surveillance features ............................................... 2-6

2.4 Disposal cell design ........................................................................... 2-9

2.5 Ground water characterization............................................................ 2-10

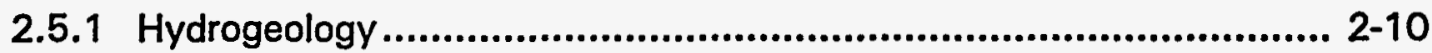

2.5.2 Background ground water quality ............................................... 2-15

2.5.3 Hazardous constituents ............................................................... 2-15

2.6 Ground water protection ................................................................. 2-17

2.6.1 Monitor well network ................................................................. 2-17

2.6.2 Concentration limits for hazardous constituents ............................. 2-20

3.0 SITE INSPECTIONS ......................................................................................... $3-1$

3.1 Inspection frequency ........................................................................ $3-1$

3.2 Inspection team .............................................................................. $3-1$

3.3 Site inspection procedures .................................................................... $3-1$

3.4 Follow-up inspections ......................................................................... $3-3$

3.5 Quality assurance ........................................................................... 3

3.6 Site inspection documentation............................................................... 3-3

3.6.1 Site inspection checklist ............................................................. 3-3

3.6.2 Site inspection maps ....................................................................... $3-4$

3.6.3 Site inspection photographs.......................................................... $3-4$

3.6.4 Field notes .................................................................................. $3-4$

3.6.5 Site inspection report ............................................................ 3-5

4.0 GROUND WATER MONITORING .................................................................. 4-1

4.1 Ground water monitoring plan ............................................................ 4-1

4.1.1 Direct ground water monitoring network ....................................... 4-1

4.1.2 Sampling frequency .................................................................... 4-1

4.1.3 Ground water monitoring team.................................................... 4-3

4.1.4 Screening monitoring and exceedance validation............................. 4-3

4.1.5 Evaluative monitoring ....................................................................... 4. 4

4.1.6 Indirect monitoring ........................................................................ 4. 4-6

4.2 Data validation and quality assurance........................................................ 4-6

4.3 Ground water monitoring documentation ................................................. 4-6 
TABLE OF CONTENTS (Concluded)

Section

Page

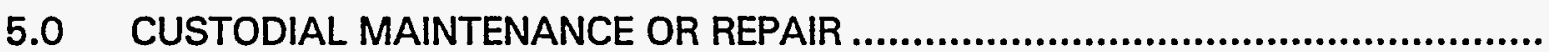

$5-1$

6.0 CORRECTIVE ACTION.. $6-1$

7.0 EMERGENCY NOTIFICATION AND RESPONSE 7-1

8.0 RECORD KEEPING AND REPORTING 8-1

9.0 REFERENCES

$9-1$

ATTACHMENT 1 SITE REAL ESTATE INFORMATION

ATTACHMENT 2 AGENCY NOTIFICATION AGREEMENTS 


\section{LIST OF FIGURES}

Eigure

2.1 Location map, Gunnison, Colorado, disposal site

2.2 Vicinity map, Gunnison, Colorado, disposal site

2.3 DOE monitor well location map, Gunnison, Colorado, disposal site

2.4 Geologic cross section (north-south) of the disposal cell vicinity, Gunnison, Colorado.

2.5 Potentiometric map of the lower Tertiary gravel aquifer, Gunnison,

Colorado, disposal site

2.6 Ground water monitoring network proposed in the Gunnison remedial action plan

\section{LIST OF PLATES}

\section{Plate}

1 Disposal site baseline map, Gunnison, Colorado, site

\section{LIST OF TABLES}

Table

2.1 Locations of permanent surveillance feattures, Gunnison, Colorado, disposal site

2.2 Monitor well information for wells completed in the Tertiary gravel aquifer, Gunnison, Colorado, disposal site

2.3 Summary of water quality data and proposed concentration limits for hazardous constituents in tailings solutions, Gunnison, Colorado, disposal site... 2-21

4.1 Sampling schedule for the monitor well network at the Gunnison, Colorado, disposal site. 4-2

4.2 Parameters to be measured during screening monitoring at the Gunnison, Colorado, disposal site. 


\section{LIST OF ACRONYMS}

$\begin{array}{ll}\text { Acronym } & \text { Definition } \\ \text { BLM } & \text { Bureau of Land Management } \\ \text { DOE } & \text { U.S. Department of Energy } \\ \text { EA } & \text { environmental assessment } \\ \text { EPA } & \text { U.S. Environmental Protection Agency } \\ \text { LTSP } & \text { long-term surveillance plan } \\ \text { MCL } & \text { maximum concentration limit } \\ \text { NGVD } & \text { National Geodetic Vertical Datum } \\ \text { NRC } & \text { U.S. Nuclear Regulatory Commission } \\ \text { POC } & \text { point of compliance } \\ \text { RAP } & \text { remedial action plan } \\ \text { TDS } & \text { total dissolved solids } \\ \text { UMTRA } & \text { Uranium Mill Tailings Remedial Action } \\ \text { UMTRCA } & \text { Uranium Mill Tailings Radiation Control Act }\end{array}$




\section{CHANGE HISTORY}

\begin{tabular}{cll}
\hline Document version & Date & \multicolumn{1}{c}{ Pages/comments } \\
\hline Rev. 0, Ver. 1 & $2 / 19 / 96$ & Initial version with editorial changes. \\
\hline Rev. 0, Ver. 2 & $4 / 16 / 96$ & $\begin{array}{l}\text { Final version prepared for submittal } \\
\text { to NRC. All DOE review comments } \\
\text { addressed. }\end{array}$ \\
\hline Rev. 0, Ver. 3 & $5 / 14 / 96$ & More DOE comments addressed. \\
\hline Rev. 1, Ver. 1 & $5 / 23 / 96$ & $\begin{array}{l}\text { DOE review comments incorporated; } \\
\text { minor changes. }\end{array}$ \\
\hline
\end{tabular}




\subsection{PURPOSE AND SCOPE}

This long-term surveillance plan (LTSP) describes the U.S. Department of Energy's (DOE) long-term care program for the Uranium Mill Tailings Remedial Action (UMTRA) Project Gunnison disposal site in Gunnison County, Colorado.

The U.S. Nuclear Regulatory Commission (NRC) has developed regulations for the issuance of a general license for the custody and long-term care of UMTRA Project disposal sites in 10 CFR Part 40. The purpose of this general license is to ensure that the UMTRA Project disposal sites will be cared for in a manner that protects the public health and safety and the environment. For each disposal site to be licensed, the NRC requires the DOE to submit a site-specific LTSP. The DOE prepared this LTSP to meet this requirement for the Gunnison disposal site. The general license becomes effective when the NRC concurs with the DOE's determination of completion of remedial action for the Gunnison site and the NRC formally accepts this LTSP.

This LTSP describes the long-term surveillance program the DOE will implement to ensure that the Gunnison disposal site performs as designed. The program is based on two distinct activities: 1) site inspections to identify threats to disposal cell integrity, and 2) ground water monitoring to demonstrate disposal cell performance. The LTSP is based on the UMTRA Project long-term surveillance program guidance (DOE, 1996) and meets the requirements of 10 CFR $\$ 40.27(b)$ and 40 CFR $\$ 192.03$. 


\subsection{FINAL SITE CONDITIONS}

Remedial action at the former uranium processing site in Gunnison, Colorado, consisted of excavating and relocating the residual radioactive materials to the Gunnison disposal site. The DOE constructed a disposal cell to control the residual radioactive material in accordance with 40 CFR Part 192. The Gunnison disposal site is fenced, and its perimeter is marked with warning signs. The site completion report (MK-F, 1996) contains a detailed description of the final site conditions.

\section{$2.1 \quad$ SITE HISTORY}

The Gunnison mill, which had a processing capacity of 200 tons (180 metric tons) of ore per day, operated from 1958 to 1962 . The mill ground the ore and then leached it with sulfuric acid and sodium chlorate. After leaching, the uranium-rich solutions and waste solids were separated. The solutions were then treated with sodium carbonate to extract the uranium and the washed solids were dumped in the tailings pile. During its operation, the mill processed about 540,000 tons $(490,000$ metric tons) of uranium ore.

The Uranium Mill Tailings Radiation Control Act (UMTRCA) of 1978 (42 USC $\$ 7901$ et seq.) gave the DOE authority to perform remedial action at the Gunnison processing site. The DOE evaluated the environmental impacts associated with the Gunnison site remedial action in an environmental assessment (EA) (DOE, 1992a). The NRC and the state of Colorado concurred with the DOE's remedial action plan (RAP) (DOE, 1992b) to comply with the requirements of 40 CFR Part 192, Subparts A-C.

The DOE began constructing the disposal cell in 1992. During 1993 and 1994, the DOE relocated uranium mill tailings and other residual radioactive materials (such as contaminated demolition debris, soils, and vicinity property materials) and placed them in the disposal cell. Construction of the disposal cell was completed in 1995 with placement of a radon/infiltration barrier and frost and erosion protection layers.

The DOE has prepared a completion report documenting compliance with the RAP and the site as-built conditions (MK-F, 1996). In addition, the DOE will prepare a final audit report and certification summary and submit it along with the completion report to the NRC for concurrence. Concurrence from the NRC on the completion report will be included the permanent site file.

\subsection{GENERAL DESCRIPTION OF THE SITE VICINITY}

The Gunnison disposal site is in Gunnison County in southwest Colorado on the western slope of the Rocky Mountains (Figure 2.1). The site is approximately 6 miles (mi) (10 kilometers [km]) southeast of the town of Gunnison, Colorado, in Township 49 North, Range 1 East, Section 15, New Mexico Principal Meridian (Figure 2.2). This section provides a brief description of the site vicinity; 


\section{Figure 2.1}

\section{Location Map}

\section{Gunnison, Colorado, Disposal Site}

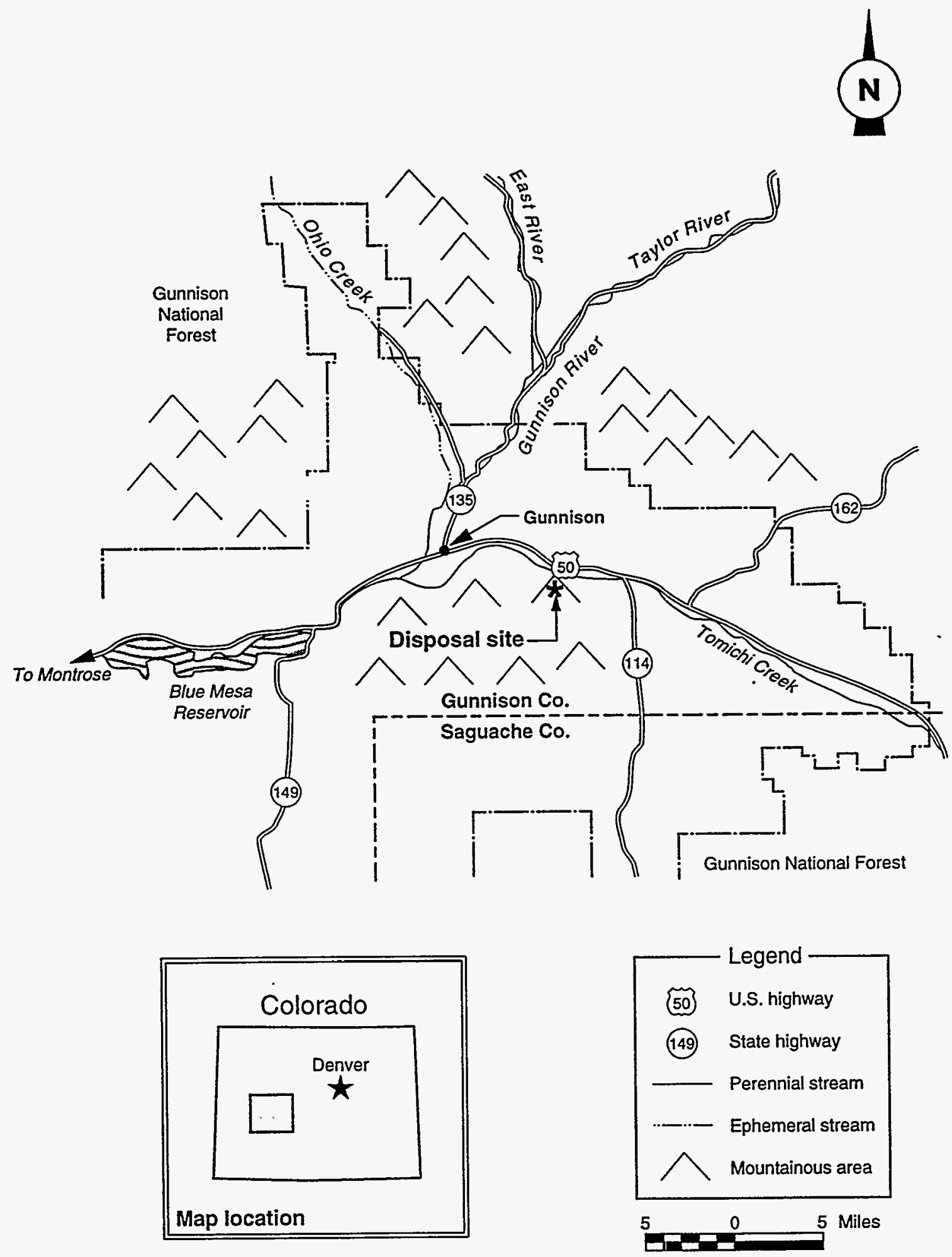


Figure 2.2

\section{Vicinity Map}

\section{Gunnison, Colorado, Disposal Site}

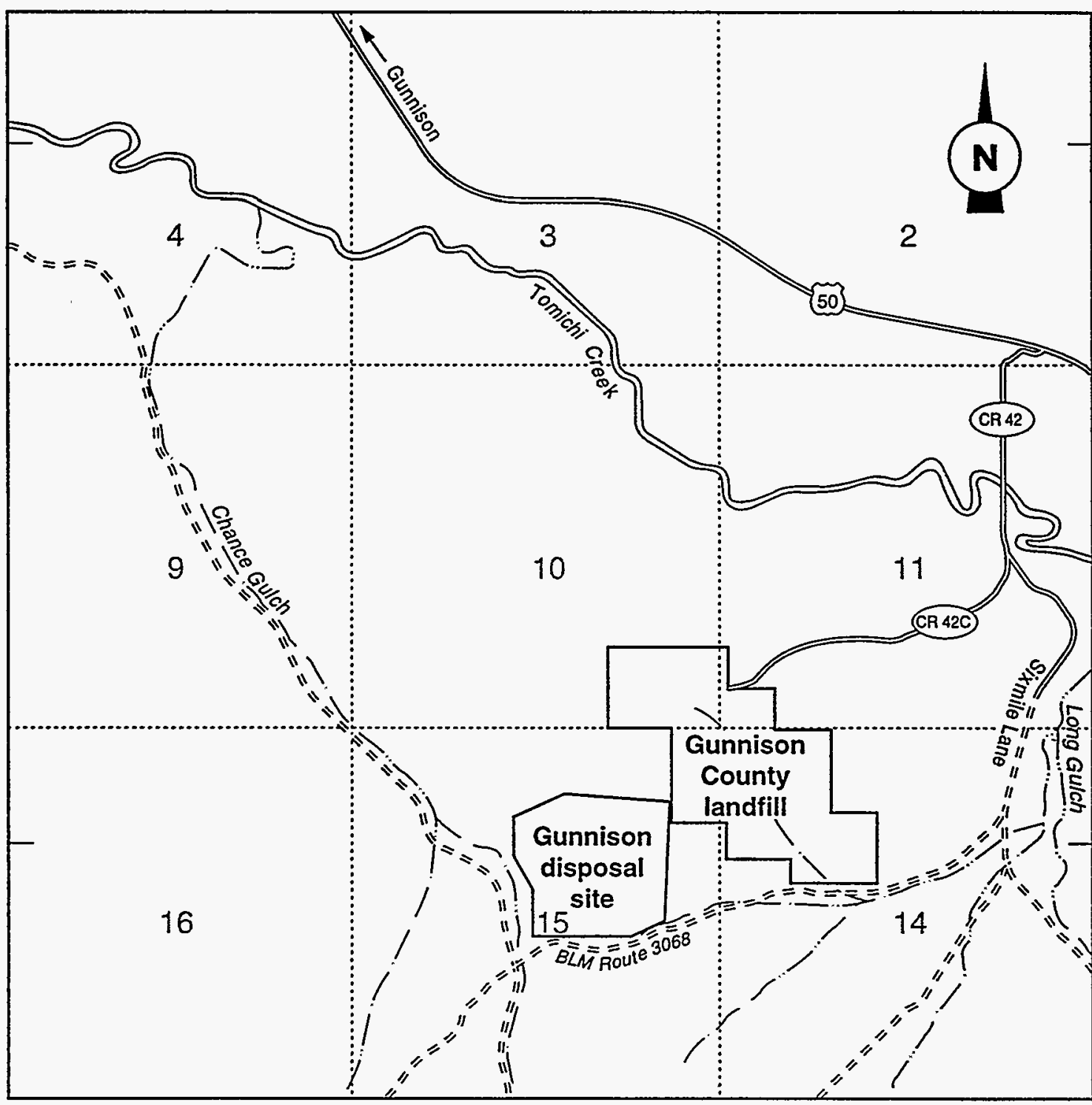

\begin{tabular}{|c|c|c|c|}
\hline 50 & U.S. highway & & Paved road \\
\hline CR 42 & County road & (.......... & Section line \\
\hline$\cdots-\cdots$ & $\begin{array}{l}\text { Ephemeral stream } \\
\text { Dirt road }\end{array}$ & 15 & $\begin{array}{l}\text { Section number } \\
\text { (T49N, R1E) }\end{array}$ \\
\hline
\end{tabular}

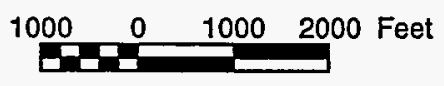

Modified from MK-F, 1996. 
detailed descriptions can be found in the site EA (DOE, 1992a) and the RAP (DOE, 1992b).

The general climatic regime in the vicinity of the Gunnison disposal site is semiarid. The area is characterized by low humidity, frequent sunny days, and large diurnal and seasonal temperature ranges. The average annual precipitation is 11 inches (280 millimeters [mm]). The highest monthly rainfall usually occurs during July and August, while the least rainfall occurs from April through June. The adjusted annual evapotranspiration for the area is approximately 10 inches $(250 \mathrm{~mm})$. Winds are highly variable and heavily influenced by the local mountain and valley topography.

The average elevation of the Gunnison disposal site is about 8040 feet ( $\mathrm{ft}$ ) (2450 meters [m]) above National Geodetic Vertical Datum (NGVD) of 1929. The site is on the southern slope of an $8402-\mathrm{ft}(2561-\mathrm{m})$-high mountain, and is bounded on the west by Chance Gulch and on the east by Long Gulch. The disposal site lies on a drainage divide on a very gently sloping, dissected surface. Soil formation and movement of the material within the surficial deposits are affected by seasonal freeze-thaw cycles. Sheet flow erosion appears to be the dominant process currently shaping the local topography. However, net surface erosion in the disposal site area appears to be insignificant. Some local soil erosion occurs off the site in the small rills and gullies at the heads of the large drainage channels that dissect the area.

Runoff from snowmelt and rainstorms contributes only small amounts of overland surface water flow toward the disposal site. A large gully extends along the northern boundary of the site and drains into Chance Gulch. A small gully is located on the southeastern portion of the site. Runoff in this gully flows into the drainage divide south of the disposal site, eventually draining into Long Gulch. Flooding is not considered a hazard at the site because of the distance from and elevation above Tomichi Creek, the closest perennial stream.

Most of the land in the area is primarily used for seasonal livestock grazing and wildlife habitat and, to a lesser extent, mineral extraction and recreation. There is no potential for future natural resource development in the immediate site vicinity. Additional local land use includes operation of the Gunnison County landfill, which is northeast of the disposal site. The closest residence is about $1.5 \mathrm{mi}(2.4 \mathrm{~km})$ east of the site and the nearest downgradient registered well is located $7500 \mathrm{ft}(2300 \mathrm{~m})$ from the site.

\section{$2.3 \quad$ DISPOSAL SITE DESCRIPTION}

This section provides a brief description of the disposal site; detailed descriptions can be found in the site RAP (DOE, 1992b) and completion report (MK-F, 1996). 


\subsubsection{Site ownership and legal description}

The government currently owns the Gunnison disposal site and most of the surrounding area. The Bureau of Land Management (BLM) permanently transferred administration of public land to the DOE in 1992 for use as the Gunnison disposal site. The BLM administers the adjacent surrounding lands, except for the Gunnison County landfill. Attachment 1 provides a legal description of the disposal site. Plate 1 shows the final site boundary and identifies ownership of the site and surrounding areas at the time of licensing.

\subsubsection{Directions to the disposal site}

The Gunnison disposal site can be reached by automobile via paved and graded dirt roads (Figure 2.2 ) by following these directions.

1. From Gunnison, Colorado, take U.S. Highway 50 east about $5 \mathrm{mi}(8 \mathrm{~km})$ from the junction of State Highway 135 to County Road 42.

2. Turn right (south) onto County Road 42 (also known as Sixmile Lane) and travel just over $1 \mathrm{mi}(1.6 \mathrm{~km})$ to BLM Route 3068. (Sixmile Lane turns into a dirt road past the turnoff for the Gunnison County landfill.)

3. Turn right onto BLM Route 3068 and travel west for about $1 \mathrm{mi}(1.6 \mathrm{~km})$.

4. Follow BLM Route 3068 until you come to the turnoff on the right (north) for the access gate to the site. The site access point also is marked by a site entrance sign and granite site marker located just inside the site fence.

Entry to the disposal site is restricted by a barbed-wire fence around the site perimeter. The south access gate is kept locked and the key needed to enter the site may be obtained from the DOE.

\subsubsection{Description of surface conditions}

The Gunnison disposal site is located on approximately 92 acres (ac) (37 hectares [ha]) of land (Plate 1). The completion report (MK-F, 1996) contains a detailed description of the final site conditions including the results of the final site topographic survey. The site is enclosed with a 5-strand, barbedwire fence, and the perimeter also is marked with warning signs, boundary markers, and survey monuments (Section 2.3.4). The tailings and other contaminated materials are contained in a rock-covered disposal cell located in the center of the site.

The final site grading has all areas contoured to promote drainage away from the disposal cell. The DOE used a mix of five species of grasses to revegetate all disturbed areas of the disposal site not covered by riprap (MK-ECE, 1995). 
-At the completion of remedial action, the DOE documented final disposal site conditions with site maps, as-built drawings, and ground and aerial photographs (MK-F, 1996). This information illustrates baseline conditions for comparison to future disposal site conditions. Lithologic logs and construction data for monitor wells drilled on and around the disposal site provide detailed information on site hydrogeology. All original drawings, site maps, well logs, and photographs are part of the Gunnison permanent site file.

\subsubsection{Permanent site-surveillance features}

Survey and boundary monuments, site markers, and warning signs are the permanent long-term surveillance features of the Gunnison disposal site. In addition, the disposal site also has point-of-compliance (POC) and background ground water monitor wells. Plate 1 shows the locations of these features and Table 2.1 provides their survey grid coordinates. Typical construction and installation specifications for these features are shown in the long-term surveillance guidance (DOE, 1996) and subcontract documents (MK-ECE, 1995).

Three survey monuments establish permanent horizontal control based on the Colorado State Plane Coordinate:System (Central Zone) and are referenced to the Project Survey Control Point, which is located about $700 \mathrm{ft}(210 \mathrm{~m})$ east of the southeast corner of the site at an elevation of $7923.32 \mathrm{ft}(2415.03 \mathrm{~m})$ above NGVD. The three permanent survey monuments (SM-1, SM-2, and SM-3) are Berntsen RT- 1 markers set in concrete, with the monument about 4 inches $(10 \mathrm{~cm})$ above ground level. Magnets in the markers permit easier detection if they become buried over time. The survey monument identification number is stamped on the top of the metal cap.

Eleven boundary monuments lie along the final site boundary. The three RT-1 survey monuments serve a dual purpose as boundary monuments (SM-1 as $\mathrm{BM}-1, \mathrm{SM}-2$ as $\mathrm{BM}-2$, and $\mathrm{SM}-3$ as $\mathrm{BM}-3)$. The remaining eight boundary monuments (BM-4 to BM-11) are Berntsen Model A-1 survey monuments set in concrete, with the monument about 1 inch $(25 \mathrm{~mm})$ above ground level. Magnets in the A-1 monuments allow easier detection if they become buried. The boundary monument identification number is stamped on the top of the metal cap.

Two unpolished granite markers with an incised message identify the Gunnison disposal site. The message includes a drawing showing the general location of the stabilized disposal cell within the site boundaries, the date of closure (26 July 1995), the weight of tailings $(1,140,000$ dry tons $[1,034,000$ metric tons]), and the amount of radioactivity (175 curies of radium-226). Site marker SMK-1 near the south access gate to the site is set in reinforced concrete that extends $3 \mathrm{ft}(0.9 \mathrm{~m})$ below the ground surface. Site marker SMK-2 at the crest of the disposal cell is set in reinforced concrete that extends to the top of the frost protection barrier. 
Table 2.1 Locations of permanent surveillance features, Gunnison, Colorado, disposal site

\begin{tabular}{|c|c|}
\hline Feature & Location coordinates $^{\mathrm{a}}$ \\
\hline \multicolumn{2}{|l|}{ Site markers } \\
\hline SMK-1 & $N$ 14,678; E 12,600 \\
\hline SMK-2 & N 15,539; E 12,974 \\
\hline \multicolumn{2}{|c|}{ Survey/boundary monuments } \\
\hline SM-1/BM-1 & $N$ i5,002; E 14,326 \\
\hline$S M-2 / B M-2$ & N 16,648; E 14,321 \\
\hline SM-3/BM-3 & N 16,663; E 12,500 \\
\hline \multicolumn{2}{|c|}{ Boundary monuments } \\
\hline BM-4 & N 16,394; E 11,660 \\
\hline BM-5 & N 15,828; E 11,662 \\
\hline BM-6 & N 15,343; E 11,996 \\
\hline BM-7 & $N$ 15,009; E 11,998 \\
\hline BM-8 & N 14,685; E 11,999 \\
\hline BM-9 & N 14,684; E 12,326 \\
\hline BM-10 & N 14,679; E 13,632 \\
\hline BM-11 & N 14,897; E 14,327 \\
\hline \multicolumn{2}{|l|}{ Background well } \\
\hline GUN-08-0716 & $N 17499 ; E 13,216$ \\
\hline GUN-08-0609 & N14,961; E 12,563 \\
\hline \multicolumn{2}{|l|}{ POC wells } \\
\hline GUN-08-0720 & N 15,500; E 12,370 \\
\hline GUN-08-0721 & N 16,$120 ;$ E $12,620^{b}$ \\
\hline GUN-08-0722 & N 16,$080 ;$ E $13,440^{b}$ \\
\hline GUN-08-0723 & N 15,750; E 13,670 \\
\hline GUN-08-0724 & N 15,500; E 13,500 \\
\hline GUN-08-0725 & N 15,000; E 13,370 \\
\hline
\end{tabular}


Table 2.1 Locations of permanent surveillance features, Gunnison, Colorado, disposal site (Concluded)

\begin{tabular}{lc}
\hline \multicolumn{1}{c}{ Feature } & Location coordinates $^{\mathrm{a}}$ \\
\hline Ground water level monitor wells \\
\hline GUN-08-0630 & N 14,675; E 12,524 \\
GUN-08-0634 & N 15,391; E 11,640 \\
GUN-08-0663 & N 16,780; E 13,544 \\
GUN-08-0709 & N 17,094; E 10,206 \\
GUN-08-0710 & N 13,591; E 12,679 \\
GUN-08-0712 & N 15,096; E 10,504 \\
GUN-08-0714 & N 15,385; E 16,124 \\
GUN-08-0715 & N 15,450; E 14,336 \\
\hline${ }^{2}$ Coordinates in feet based on Project Survey Control \\
Point (N 15,000; E 15,000 - modified Colorado State \\
Plane Coordinate System). \\
${ }^{b}$ Estimated coordinates based on proposed well \\
locations. \\
From MK-ECE, 1995. \\
POC - point of compliance.
\end{tabular}


The DOE has posted property use warning signs $(18$ inches $[460 \mathrm{~mm}$ ] by 24 inches [610 $\mathrm{mm}]$ ) around the disposal site perimeter at approximately 200-ft $(60-\mathrm{m})$ intervals. These warning signs (41 total) are attached to the perimeter fences. The site entrance sign is at the south access gate to the disposal site near site marker SMK-1. The entrance sign also displays the DOE 24-hour phone number to call concerning the site.

The Gunnison disposal site will have six POC monitor wells, two background wells, and eight ground water-level monitor wells (see Section 2.6.1) in the uppermost aquifer. The DOE installs and develops ground water monitor wells in accordance with U.S. Environmental Protection Agency (EPA) guidance (EPA, 1986). The lithologic logs for background wells (GUN-08-0716 and GUN-080609) and ground water level-monitoring wells (Table 2.1) are in the site file. Logs for the POC wells will be added to the site file after the wells have been installed.

\section{$2.4 \quad$ DISPOSAL CELL DESIGN}

The 29-ac (12-ha) disposal cell is located on an alluvial slope upland from any active stream channels. The area of the disposal cell is not subject to any significant hazard from slope failure processes such as landslides, debris flows, mud flows, and rock falls. The geomorphic processes posing a potential hazard to the stabilized disposal cell are ephemeral drainage channel changes, lowgradient slope erosion, and wind erosion; however, these processes are not reasonably expected to affect the disposal cell within the next 1000 years, or in any case for at least 200 years.

The disposal cell is constructed partially below grade and rises above the surrounding terrain to a maximum elevation of about $8065 \mathrm{ft}(2458 \mathrm{~m})$ above NGVD. The disposal cell contains approximately 740,000 cubic yards $\left(565,000\right.$ cubic meters $\left.\left[\mathrm{m}^{3}\right]\right)$ of relocated tailings and other residual radioactive materials, primarily contaminated soil and demolition debris. The disposal cell is capped with a 9-ft (3-m)-thick multiple-component cover.

An 1.5-ft $(0.45-\mathrm{m})$-thick radon/infiltration barrier is placed over the contaminated materials. This barrier is constructed of clayey soil amended with bentonite and is designed to reduce the radon-222 flux from the disposal cell to less than 20 picocuries per square meter per second and minimize water infiltration into the tailings. A 6-ft (2-m)-thick layer of compacted soil lies on top of the radon/infiltration barrier to prevent the clayey barrier from being adversely affected by freezing and thawing cycles. A 0.5-ft $(0.15-\mathrm{m})$-thick, coarse-grained bedding layer is between the radon/infiltration barrier and the frost protection barrier to provide a capillary break and promote drainage of infiltrating water away from the radon barrier. The topslopes and sideslopes of the disposal cell are capped with rock to protect against wind and water erosion and prevent damage to the underlying radon/infiltration barrier. A rock-lined diversion ditch abuts the upslope portion of the disposal cell to divert surface flow away from the cell. 
The erosion protection layer is $0.5-\mathrm{ft}(0.15-\mathrm{m})$-thick riprap on the topslopes and $1-\mathrm{ft}(0.3-\mathrm{m})$-thick riprap on the sideslopes. A $0.5-\mathrm{ft}(0.15-\mathrm{m})$-thick bedding layer is between the riprap and the radon/infiltration barrier to prevent damage to the barrier by rocks and loss of the fined-grained radon/infiltration barrier material. The maximum grade is 2.5 percent on the topslopes and 33 percent on the sideslopes. These grades, in conjunction with the bedding layer, will allow excess surface water to run off the disposal cell and be conveyed to adjacent site grades in a manner that minimizes the risk of significant erosion. The components of both the topslope and sideslope covers are intended to minimize the potential for deep percolation of precipitation into the residual radioactive material.

At the toe of the disposal cell there is a riprap apron, varying in thickness from $1.5 \mathrm{ft}(0.45 \mathrm{~m})$ to $4 \mathrm{ft}(1.2 \mathrm{~m})$. At the ground surface, riprap protection extends up to $20 \mathrm{ft}(6 \mathrm{~m})$ from the toe of the disposal cell. The 1800-ft $(550-\mathrm{m})$-long diversion ditch is also lined with riprap.

Detailed engineering drawings of the disposal cell are in the site completion report (MK-F, 1996).

\subsection{GROUND WATER CHARACTERIZATION}

This section briefly describes the hydrogeologic units and background ground water quality at the Gunnison disposal site and identifies the constituents of concern at the site. More detail on ground water characterization of the site is found in the Gunnison RAP (DOE, 1992b).

\subsubsection{Hydrogeology}

The hydrogeology of the Gunnison disposal site was characterized during preparation of the RAP (DOE, 1992b). The locations of monitor wells installed during the characterization efforts are presented in Figure 2.3. Four regional Tertiary hydrogeologic units underlie a thin veneer of recent alluvium at the disposal site. In descending order these units are 1) upper Tertiary gravels that form an unsaturated zone, 2) lahar breccia and undifferentiated volcaniclastic mudflows that comprise a low permeability semiconfining zone, 3) lower Tertiary gravels that comprise the uppermost (regional) aquifer, and 4) undifferentiated Tertiary gravels to the north where the intervening volcaniclastic mudflow pinches out. A geologic cross section is provided in Figure 2.4. Both the upper and lower Tertiary gravels consist of silty and clayey sand, subrounded cobbles, and welded tuff. The lahar breccia and volcaniclastic mudflows mentioned above generally form a semiconfining zone that prohibits or retards the movement of ground water downward to the lower Tertiary gravels (uppermost aquifer). In the northern portion of the project site, where the lahar breccia is absent, the upper and lower Tertiary gravels are essentially one hydrogeologic unit. 
Figure 2.3

DOE Monitor Well Location Map

Gunnison, Colorado, Disposal Site

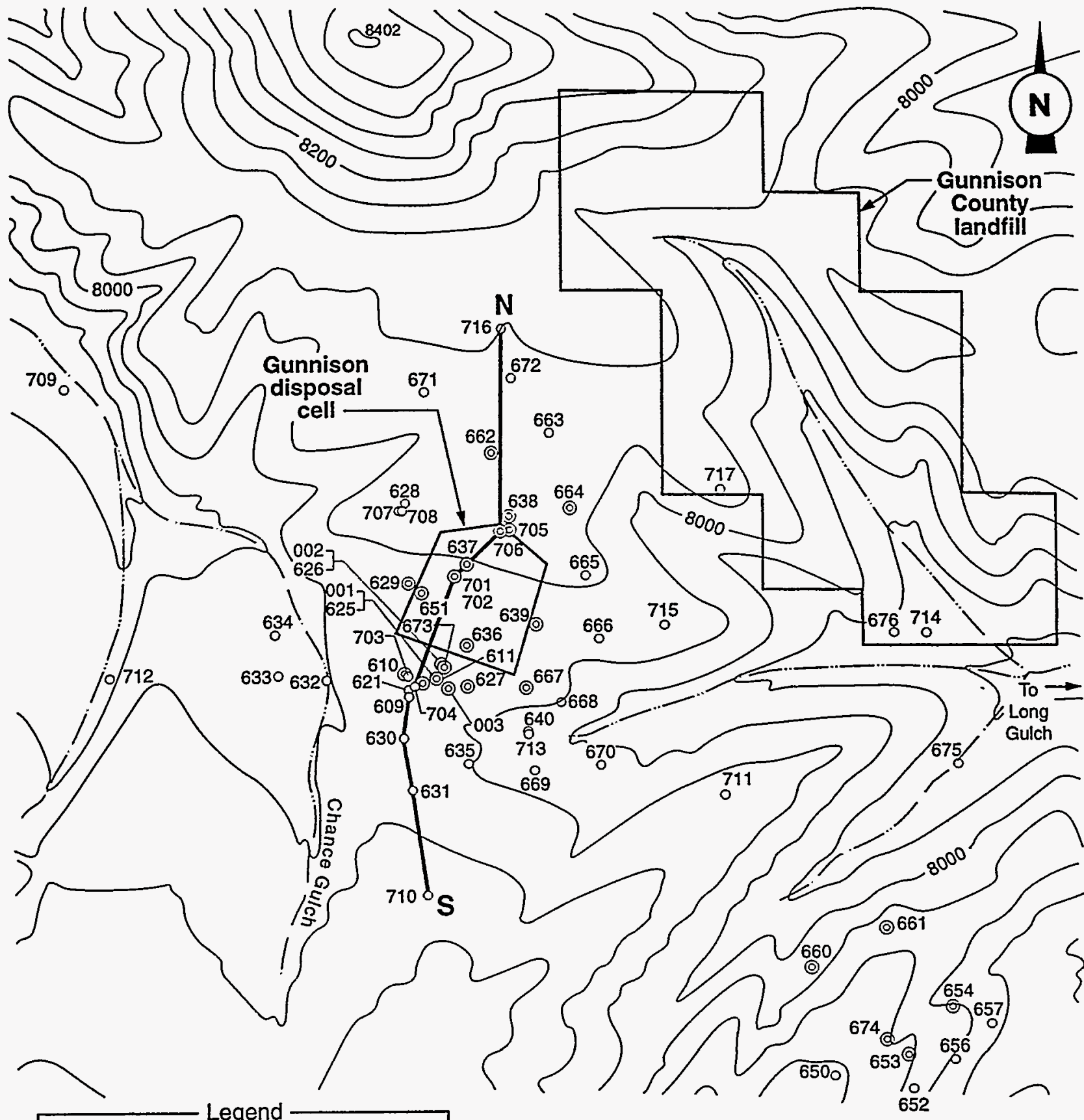

Legend

Note: Contour intervals $=40 \mathrm{ft}$.

- 716 Existing DOE monitor well

() 667 Abandoned DOE monitor well

-...... Ephemeral stream

$\mathrm{N}-\mathrm{S}$ Cross section line

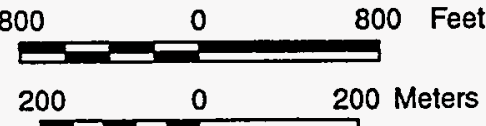

MAC: SITEIGINNLTSPIMONWELLOC 
Figure 2.4

Geologic Cross Section (North-South) of the Disposal Cell Vicinity

Gunnison, Colorado

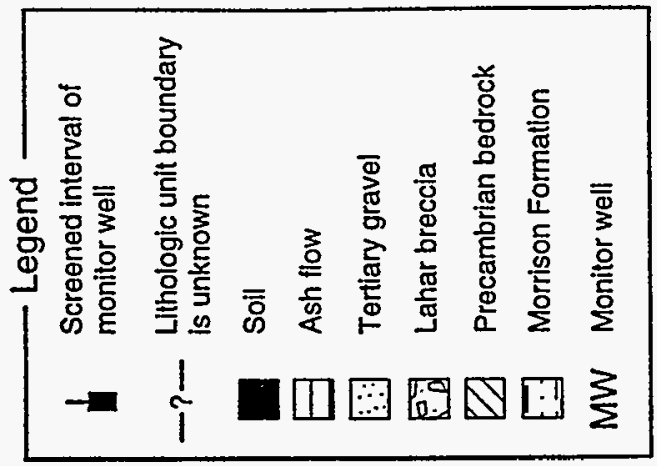

$\boldsymbol{\infty}$
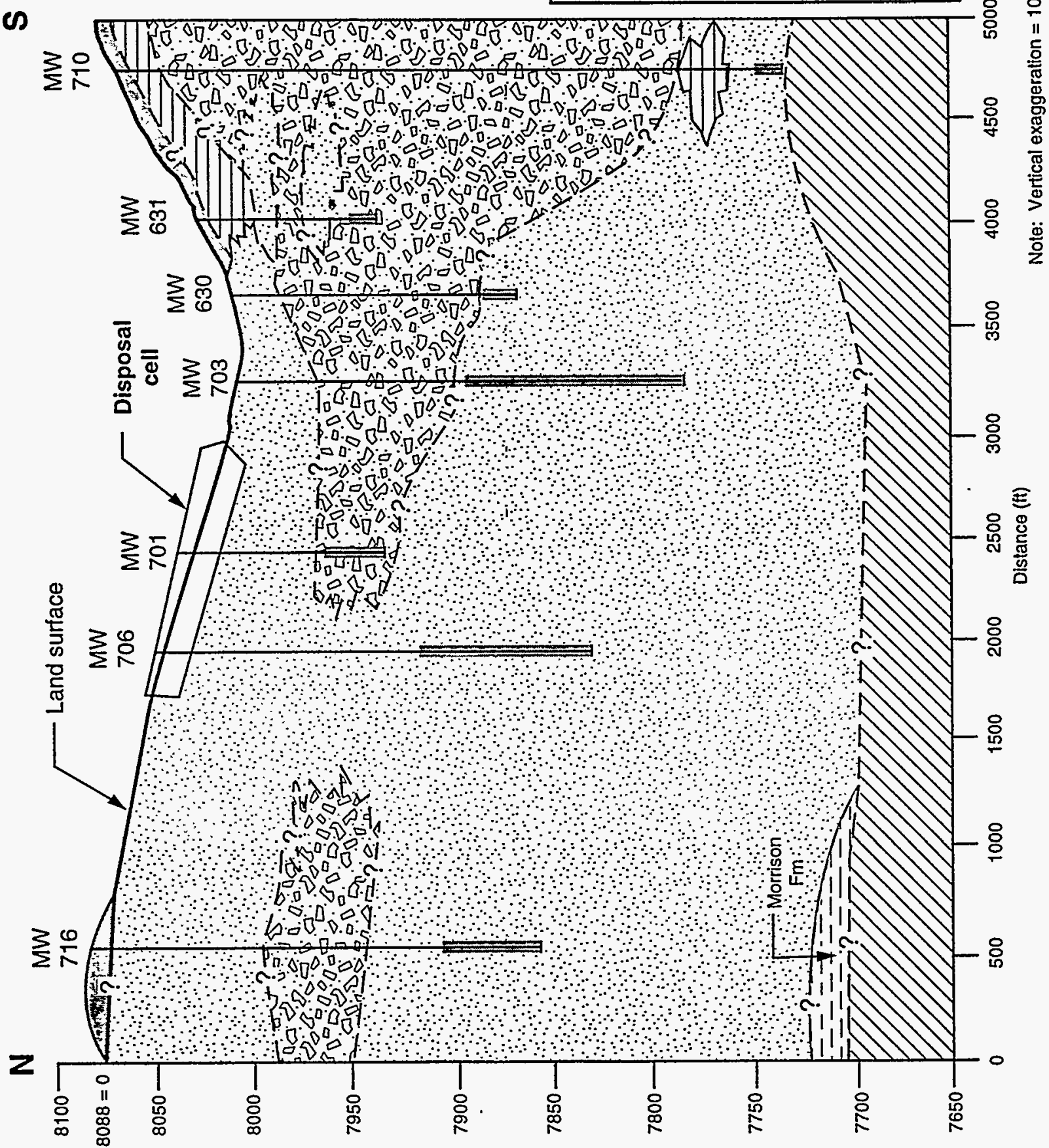

(4) әseunns pue! molaq ųdəo

MAC: SITL/GUN/LTSP;GEOX-SEC (N-S)$$
\text { Mog undeO }
$$ 
The Jurassic Morrison Formation, Jurassic Junction Creek Sandstone, and Precambrian metasedimentary and gneissic crystalline rock underlie the Tertiary gravels. The depth to these units averages $300 \mathrm{ft}(90 \mathrm{~m})$ below the surface.

At the Gunnison disposal site, the uppermost aquifer occurs in the lower portion of a regional Tertiary gravel unit; the top of the aquifer is, on average, $110 \mathrm{ft}$ $(34 \mathrm{~m})$ below the disposal cell. Material thickness of the uppermost aquifer ranges from 43 to $240 \mathrm{ft}(13$ to $73 \mathrm{~m})$ and averages $170 \mathrm{ft}(52 \mathrm{~m})$. A semiconfining zone composed primarily of the lahar breccia and volcaniclastic mudflow strata extends from the south and intertongues with the Tertiary gravels beneath the site. The semiconfining zone is present beneath the disposal cell but absent in the northern portion of the site area. Because wells completed within the volcaniclastic strata are incapable of yielding 150 gallons $\left(0.57 \mathrm{~m}^{3}\right)$ per day per year, these strata are not considered to be an aquifer at the disposal site (DOE, 1992b).

Figure 2.5 is a potentiometric map of the lower Tertiary gravel aquifer. Because the disposal site is located within a topographic saddle, ground water flow at the disposal site is complex. In the immediate vicinity of the UMTRA Project disposal site, the primary component of flow is east, following the general topographic trend toward Long Gulch. However, as shown in Figure 2.5, a ground water divide is present in the disposal cell area causing a component of ground water beneath the site to flow to the west. The quality of the ground water under the Gunnison County landfill is not expected to affect the disposal site, as discussed in the RAP (DOE, 1992b).

Aquifer testing shows the uppermost aquifer responds as a confined aquifer when the lahar breccia and volcaniclastic deposits are present. Because the hydraulic conductivity of the lahar breccia and volcaniclastic deposits is very low (0.007 ft per day $\left[2.5 \times 10^{-7} \mathrm{~cm}\right.$ per second] or less) (DOE, 1992b), they act as an aquitard to the downward movement of water. The hydraulic conductivity of the Tertiary gravel aquifer ranges from 0.4 to $0.5 \mathrm{ft}$ per day 10.0001 to $0.0002 \mathrm{~cm}$ per second). No lateral boundaries were observed during two aquifer pumping tests ( 24 and 72 hours in duration) in the lower Tertiary gravel aquifer, and none of the monitor wells completed in the lahar deposits responded to pumping in the lower Tertiary gravel aquifer. In the lower Tertiary gravel aquifer, the primary (easterly) horizontal hydraulic gradient ranges from 0.004 to 0.014 , and averages 0.010 (DOE, 1992b). Linear velocities of the uppermost aquifer were calculated by applying Darcy's Law using the calculated range of hydraulic conductivities, 0.4 to $0.5 \mathrm{ft}$ per day $(0.0001$ to $0.0002 \mathrm{~cm}$ per second); hydraulic gradients, 0.004 to 0.014 ; and an assumed porosity value of 0.25 for gravelly material appropriate for the site (Freeze and Cherry, 1979; Davis and DeWiest, 1966). From this calculation, the average linear ground water velocities in the uppermost aquifer (Tertiary gravels) are estimated to range from 2 to $10 \mathrm{ft}$ per year $\left(2 \times 10^{-6}\right.$ to $1: 0 \times 10^{-6} \mathrm{~cm}$ per second), averaging approximately $7 \mathrm{ft}$ per year $\left(7 \times 10^{-6} \mathrm{~cm}\right.$ per second) (DOE, 1992b). 


\section{Figure 2.5}

\section{Potentiometric Map of the Lower Tertiary Gravel Aquifer}

Gunnison, Colorado, Disposal Site

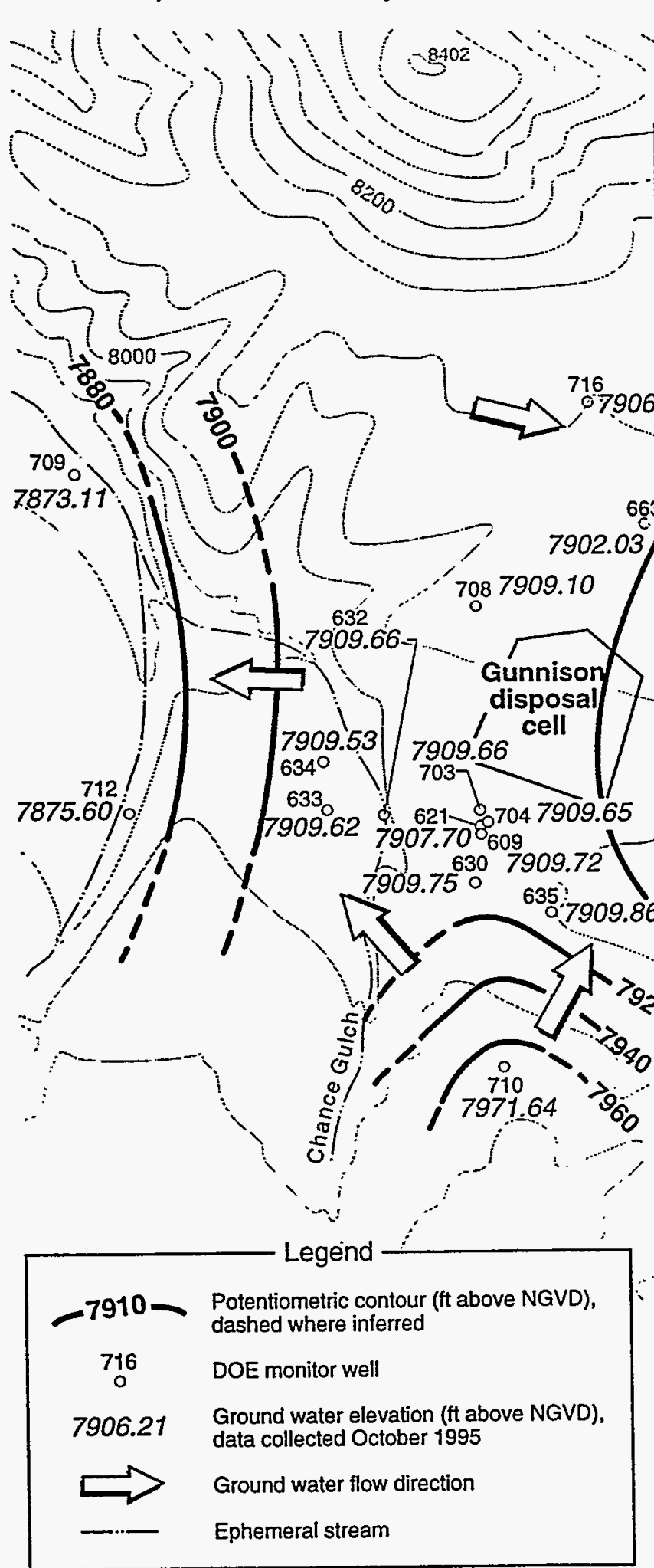

Note: Contour intervals $=40 \mathrm{ft}$.

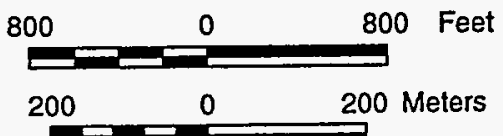

MAC: SITEJGUNLTSPIPOTENLOWATERT 


\subsubsection{Background ground water quality}

Periodic water quality sampling has been conducted at the Gunnison disposal site since 1988. Background water quality has been determined for the Tertiary gravel aquifer and the overlying semiconfining lahar breccia and volcaniclastic unit. A discussion of the water quality in the semiconfining lahar volcaniclastic unit is provided in the RAP (DOE, 1992b). As discussed in the RAP, monitoring within the semiconfining unit is not required; therefore, background water quality for this unit is not presented in this LTSP.

Table 2.2 provides construction information for 16 monitor wells sampled to determine background ground water quality in the Tertiary gravel aquifer. Background water quality was determined using wells that were sampled only before the start of disposal cell construction (June 1992) and wells located upgradient of the site that have been sampled since the start of cell construction. Water quality data collected from these wells cannot be affected by potential releases from the disposal cell.

Water quality data for the disposal cell site indicate that there are small but distinct differences in background water quality in the uppermost aquifer (the lower Tertiary gravel aquifer). Ground water south and southeast of the cell has slightly greater concentrations of total dissolved solids (TDS) and major elements when compared to ground water to the north and northeast of the cell. For example, sulfate concentrations average $65 \mathrm{mg} / \mathrm{L}$ south of the cell, and $14 \mathrm{mg} / \mathrm{L}$ north of the cell. The disposal cell is at the boundary between these two types of background ground water and thus ground water at the POC likely includes both the higher and lower TDS types. In general, there are little or no differences in background trace element concentrations (e.g., uranium and arsenic) between the two types of ground water.

The $\mathrm{pH}$ values in background ground water quality in the uppermost aquifer range from 6.9 to 9.9 . TDS concentrations range from 206 to 417 milligrams per liter $(\mathrm{mg} / \mathrm{L})$. Analyses of background ground water samples indicate that concentrations of arsenic, net gross alpha, and radium-226 and -228 slightly exceeded the EPA UMTRA Project maximum concentration limits (MCL) (Table 1 of 40 CFR Part 192 Subpart Al in the Tertiary gravels in one or more DOE monitor wells (GUN-08-0609, -0610, -0626, -0630, -0632, -0639, -0663, -0704 , and -0715$)$. Because the occurrences of these concentrations in excess of the EPA MCLs were noted prior to tailings placement in the disposal cell, the exceedances are believed to be caused by naturally occurring sources in the aquifer materials that are leaching into the ground water system.

\subsubsection{Hazardous constituents}

Ground water samples initially were evaluated for hazardous constituents generally expected to be in or derived from the residual radioactive materials related to the uranium processing activities. The list of constituents was 
Table 2.2 Monitor well information for wells completed in the Tertiary gravel aquifer, Gunnison, Colorado, disposal site

\begin{tabular}{|c|c|c|c|c|c|c|}
\hline \multirow[b]{3}{*}{ Well } & & & \multicolumn{4}{|c|}{$\begin{array}{c}\text { Screened interval } \\
\text { (depth below surface) }\end{array}$} \\
\hline & \multicolumn{2}{|c|}{ Well diameter } & \multicolumn{2}{|c|}{ (ft) } & \multicolumn{2}{|c|}{ (m) } \\
\hline & (inches) & $(\mathrm{cm})$ & top & bottom & top & bottom \\
\hline $609^{a}$ & 2 & 5 & 138 & 148 & 42 & 45 \\
\hline $610^{a, b}$ & 2 & 5 & 137 & 147 & 42 & 45 \\
\hline $626^{a, b}$ & 2 & 5 & 130 & 140 & 40 & 43 \\
\hline $630^{a}$ & 4 & 10 & 127 & 137 & 39 & 42 \\
\hline $632^{a}$ & 4 & 10 & 105 & 115 & 32 & 35 \\
\hline $634^{a}$ & 4 & 10 & 95 & 105 & 29 & 32 \\
\hline $635^{a}$ & 4 & 10 & 151 & 161 & 46 & 49 \\
\hline $637^{a, b}$ & 4 & 10 & 157 & 167 & 48 & 51 \\
\hline $638^{a, b}$ & 4 & 10 & 166 & 176 & 51 & 54 \\
\hline $639^{a, b}$ & 4 & 10 & 147 & 157 & 45 & 48 \\
\hline $663^{a}$ & 2 & 5 & 171 & 173 & 52 & 53 \\
\hline $703^{a}$ & 4 & 10 & 229 & 349 & 70 & 106 \\
\hline $704^{a}$ & 6 & 15 & 107 & 227 & 33 & 69 \\
\hline $708^{a}$ & 4 & 10 & 155 & 165 & 47 & 50 \\
\hline 713 & 4 & 10 & 205 & 215 & 62 & 66 \\
\hline 714 & 4 & 10 & 134 & 144 & 41 & 44 \\
\hline 715 & 4 & 10 & 132 & 172 & 40 & 52 \\
\hline $716^{a}$ & 4 & 10 & 185 & 225 & 56 & 69 \\
\hline $717^{\mathrm{a}}$ & 4 & 10 & 160 & 200 & 49 & 61 \\
\hline
\end{tabular}

${ }^{\mathrm{a}}$ Data from these wells collected between February 1988 and April 1992 or October 1995 were used to establish background water quality.

${ }^{b}$ Well decommissioned after April 1992.

modified during subsequent sampling events to reflect hazardous constituents related to uranium processing activities at the Gunnison processing site (DOE, 1994). After evaluating existing ground water quality data, the DOE chose the following constituents by comparing potentially hazardous constituents detected in the tailings source term and their relative concentrations in background ground water: 


- antimony
- arsenic
- ceryllium
- cadmium
- chromium
- cobalt
- copper

- net gross alpha

- lead

- molybdenum

- nickel

- nitrate

- radium-226 and -228

- selenium

\subsection{GROUND WATER PROTECTION}

The ability of the disposal cell to protect ground water depends on its engineering features. The design of the disposal cell minimizes contaminant migration from the disposal cell into foundation materials. The disposal cell will meet established ground water concentration limits at the POC wells in the uppermost aquifer because:

1. The multicomponent disposal cell cover will limit infiltration of precipitation into the cell, thereby minimizing long-term leaching of hazardous components from the tailings.

2. The contaminated materials were placed at a moisture content that produces almost no transient drainage. The placement moisture content of the tailings is approximately equal to the in situ moisture content. The use of water for construction and dust suppression was controlled. As a result, very little seepage will be transmitted through the unsaturated zone during the design life of the disposal cell.

3. Depth to the uppermost aquifer averages over $100 \mathrm{ft}(30 \mathrm{~m})$; the aquifer is confined by a dense, clayey unit beneath the disposal cell.

4. Geochemical characteristics of the foundation soils and rock are favorable for attenuating hazardous constituents in tailings seepage from the base of the disposal cell. Hazardous constituents that exceed the MCLs or statistical maximum background concentrations are precipitated or adsorbed in the unsaturated zone before they reach the water table in the uppermost aquifer.

\subsubsection{Monitor well network}

The Gunnison RAP (DOE, 1992b) recommended monitoring at six POC monitor wells, existing background DOE monitor wells upgradient of the disposal cell, and existing DOE monitor wells downgradient from the proposed POC wells (including wells 663 and 716). Currently, water samples are collected from eight monitor wells at the disposal site. The sampled wells are GUN-08-0663, $-0707,-0708$, and -0713 through -0717 . The sampling of these wells, as proposed in the RAP, will be altered under the LTSP (Table 2.1). The monitor well network proposed under the LTSP is shown in Figure 2.6. Justification for the modifications to the ground water monitoring network is provided below. 
The monitor well network for long-term surveillance monitoring will included six POC wells and two background monitor wells. The six POC wells will be installed approximately $50 \mathrm{ft}(15 \mathrm{~m})$ from the disposal cell around the east, west, and north perimeter ( Figure 2.6 and Plate 1). These wells will be installed and developed in accordance with standard operating procedures that are consistent with the EPA guidance (EPA, 1986) to ensure that representative ground water samples are collected. These wells will be located downgradient of the disposal cell and screened in the lower Tertiary gravels (the uppermost aquiferl. The close proximity of the wells to the disposal cell will allow for early detection of any potential contaminant releases.

The location, proposed in the RAP, of one of the POC wells (GUN-08-0722) has been changed under the LTSP. The original location was at the northernmost tip of the disposal cell and thus crossgradient from the cell. Under the LTSP, POC well -0722 will be located about 300 feet $(90 \mathrm{~m})$ east-southeast of the northern tip of the cell (Plate 1 and Figure 2.6). This will place the well downgradient rather than crossgradient from the cell.

Existing wells GUN-08-0609 and -0716 will be the background ground water monitor wells (Plate 1). These wells will be monitored to detect any changes in ground water conditions that are unrelated to the disposal cell itself, such as changes in ground water elevations or ground water chemistry. Water analyses from these wells will be compared to water analyses obtained from the POC wells to detect any possible releases from the disposal cell into the uppermost aquifer. These two wells represent the higher TDS (well 609) and lower TDS (well 716) background ground water at the disposal cell (Section 2.5.2).

Water quality sampling of existing downgradient monitor wells GUN-08-0714, -0715 , and -0717 will not be part of long-term surveillance monitoring, and their periodic sampling will be discontinued upon implementation of this LTSP. These wells will not be monitored because the six POC wells provide sufficient coverage for compliance monitoring. Background water quality in monitor wells GUN-08-0707, -0708, -0663, and -0713 will not be included in the long-term surveillance monitoring because the background historical ground water quality has been sufficiently characterized.

As part of the LTSP, water levels will be routinely measured in selected wells located away from the disposal cells. Wells $-0710,-0712,-0709$, and -0714 will be used to monitor regional water level changes along a wide perimeter around the disposal cell. Wells $-0630,-0634,-0663$, and -0715 will be used to monitor regional changes in ground water closer to the disposal cell (Figure 2.6). The purpose is to monitor potential regional changes in water levels or hydrologic gradients that could influence ground water levels and flow beneath the cell. 


\section{Figure 2.6}

\section{Proposed Ground Water Monitoring Network}

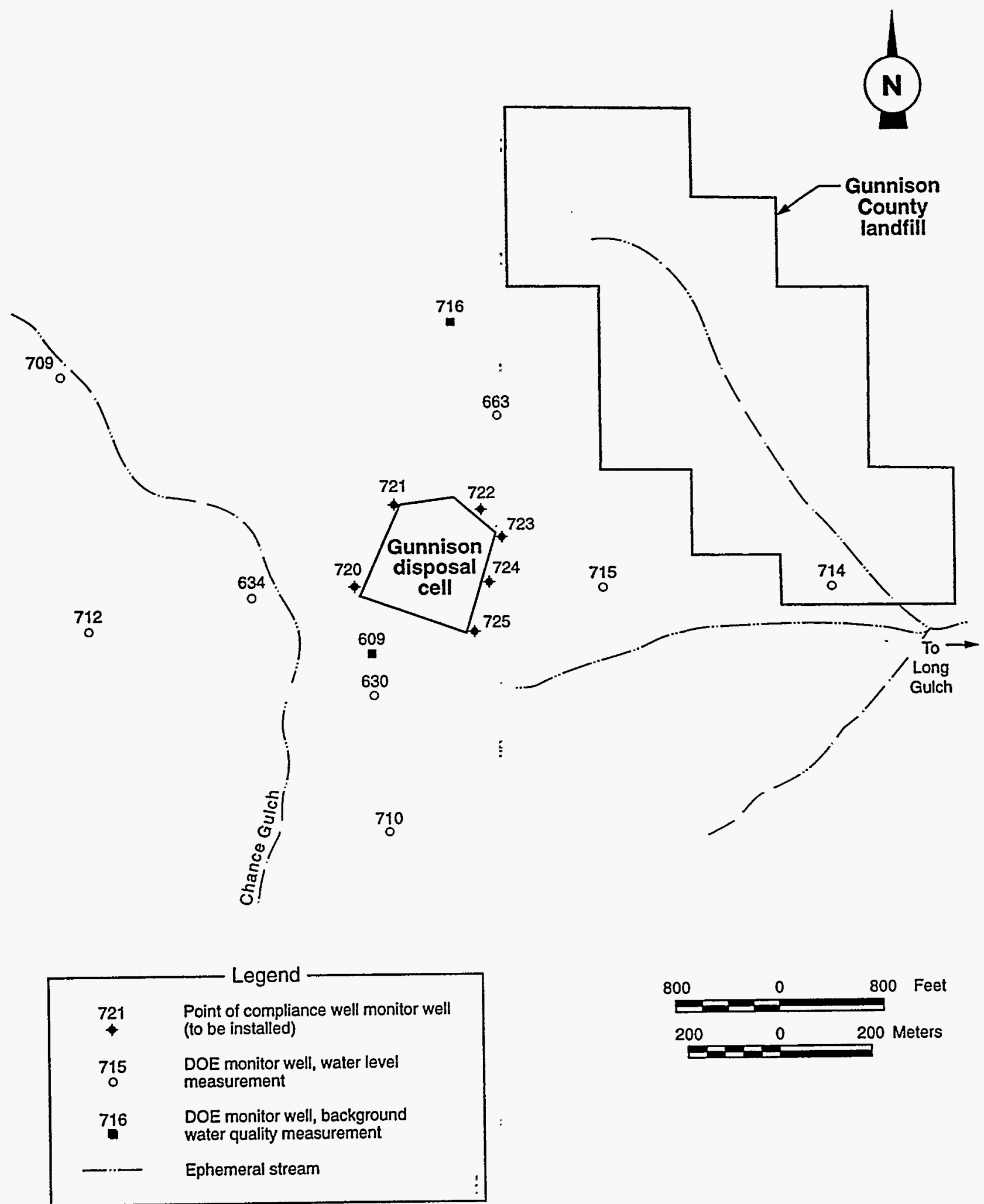

MAC: SITE/GUN/LTSP/POC-GWNET 


\subsubsection{Concentration limits for hazardous constituents}

Concentration limits for long-term monitoring of the disposal cell (Table 2.3) were established following EPA guidance (EPA, 1992). In their guidance, the EPA endorses the use of tolerance intervals for detecting contamination above background in downgradient wells. A tolerance interval is designed to contain all but a small percentage of all future measurements from wells accessing uncontaminated water. Therefore, repeated exceedances of the upper tolerance limit present statistical evidence of contamination.

A nonparametric approach was used to determine a tolerance interval for the hazardous constituents of concern at the Gunnison site. Using this approach, the upper tolerance limit is the maximum observed concentration in water samples collected between 1988 and 1995 from selected wells completed in the uppermost aquifer (Table 2.2). Because the disposal cell is located in an area where the uppermost aquifer is influenced by two types of background ground water, it is appropriate to combine the data from both types for statistical analysis. Thus, at the Gunnison site, the maximum concentrations are based on databases ranging from 51 measurements for thallium up to 73 measurements for arsenic, cadmium, chromium, lead, molybdenum, net gross alpha, radium226 and -228 , uranium, and zinc. There is 95 percent confidence the maximum observed concentration of each constituent represents a level that will exceed background no more than 5 percent of the time. Therefore, using the maximum observed concentration as a concentration limit for long-term ground water monitoring produces reasonable protection against false-positive results from random background variation.

Regulations allow the concentration limits for hazardous constituents listed in 40 CFR Part 192 to be set at the background concentrations or MCLs, whichever are greater. Therefore, the proposed concentration limits for hazardous constituents listed in Table 2.3 represent the larger of the maximum observed concentration and the UMTRA Project MCL for constituents with established MCLs. 


\begin{tabular}{|c|c|c|c|c|c|c|c|c|c|}
\hline \multirow{3}{*}{ 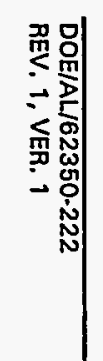 } & $\begin{aligned} \text { Table } 2.3 & \begin{array}{l}\text { Summa } \\
\text { solution }\end{array}\end{aligned}$ & $\begin{array}{l}\text { of wate } \\
\text { Gunnisc }\end{array}$ & $\begin{array}{l}\text { quality da } \\
\text {, Colorad }\end{array}$ & $\begin{array}{l}\text { and propo: } \\
\text { disposal si }\end{array}$ & concentrati & limits fo & azardous c & stituents ir & ailings \\
\hline & \multirow[b]{2}{*}{ Constituent } & \multirow[b]{2}{*}{ MCL } & \multicolumn{3}{|c|}{ Tailings solutions } & \multicolumn{3}{|c|}{ Background $^{\mathbf{b}}$} & \multirow{2}{*}{$\begin{array}{c}\text { Proposed } \\
\text { concentration } \\
\text { limit }\end{array}$} \\
\hline & & & $\begin{array}{c}\text { No. of } \\
\text { samples }\end{array}$ & Median & Maximum & $\begin{array}{l}\text { No. of } \\
\text { samples }\end{array}$ & Median & Maximum & \\
\hline \multirow{18}{*}{ N } & Hazardous constitue & s with $M$ & & & & & & & \\
\hline & Arsenic & 0.05 & 43 & 8.3 & 1,760 & 73 & 0.03 & 0.10 & $0.1^{c}$ \\
\hline & Cadmium & 0.01 & 43 & 0.691 & 14.2 & 73 & $<0.001$ & 0.001 & 0.01 \\
\hline & Chromium & 0.05 & 43 & 0.16 & 3.9 & 73 & $<0.01$ & 0.02 & 0.05 \\
\hline & Lead & 0.05 & 42 & $<0.01$ & 1.9 & 73 & $<0.01$ & 0.03 & 0.05 \\
\hline & Molybdenum & 0.10 & 43 & 0.27 & 12.5 & 73 & $<0.01$ & 0.04 & 0.10 \\
\hline & Net gross alpha & 15 & 6 & 3,070 & 22,317 & 73 & 1.8 & 28 & $28^{c}$ \\
\hline & Nitrate & 44 & 25 & 5.9 & 190 & 71 & $<1$ & 13 & 44 \\
\hline & Radium-226, -228 & 5 & 5 & 16.2 & 843 & 73 & 0.9 & 8.0 & $8^{c}$ \\
\hline & Selenium $^{a}$ & 0.01 & 44 & $<0.005$ & 60 & 70 & $<0.005$ & $<0.005$ & 0.01 \\
\hline & Uranium & 0.044 & 42 & 0.81 & 190 & 73 & 0.002 & 0.027 & 0.044 \\
\hline & Hazardous constitue & swithou & MCLs & & & & & & \\
\hline & Antimony & - & 34 & 0.018 & 0.156 & 58 & $<0.003$ & 0.012 & 0.012 \\
\hline & Beryllium & - & 30 & 0.16 & 1.14 & 58 & $<0.005$ & $<0.01$ & $0.005^{b}$ \\
\hline & Cobalt & - & 30 & 15.4 & 63.2 & 58 & $<0.05$ & $<0.05$ & $0.05^{b}$ \\
\hline & Copper & - & 43 & 9.34 & 96 & 58 & $<0.02$ & $<0.02$ & $0.02^{b}$ \\
\hline & Nickel & - & 43 & 15.4 & 99 & 58 & $<0.04$ & $<0.04$ & $0.04^{b}$ \\
\hline & Thallium $^{\mathrm{a}}$ & - & 19 & 0.02 & 0.35 & 51 & $<0.005$ & $<0.1$ & $0.005^{b}$ \\
\hline \multirow{3}{*}{ 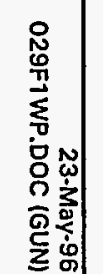 } & $\operatorname{Tin}^{a}$ & - & 21 & $<0.005$ & 0.11 & 58 & $<0.005$ & $<0.05$ & $0.05^{b}$ \\
\hline & Vanadium & - & 43 & 0.29 & 13 & 72 & $<0.01$ & 0.02 & 0.02 \\
\hline & Zinc & - & 43 & 45.5 & 369 & 73 & 0.005 & 0.06 & 0.06 \\
\hline
\end{tabular}


Table 2.3 Summary of water quality data and proposed concentration limits for hazardous constituents in tailings solutions, Gunnison, Colorado, disposal site (Concluded)

\begin{tabular}{|c|c|c|c|c|c|c|c|c|}
\hline \multirow[b]{2}{*}{ Constituent } & \multirow[b]{2}{*}{$\mathrm{MCL}$} & \multicolumn{3}{|c|}{ Tailings solutions } & \multicolumn{3}{|c|}{ Background $^{b}$} & \multirow{2}{*}{$\begin{array}{c}\text { Proposed } \\
\text { concentration } \\
\text { limit }\end{array}$} \\
\hline & & $\begin{array}{c}\text { No. of } \\
\text { samples }\end{array}$ & Median & Maximum & $\begin{array}{c}\text { No. of } \\
\text { samples }\end{array}$ & Median & Maximum & \\
\hline \multicolumn{9}{|c|}{ General water quality indicators } \\
\hline Alkalinity & - & 2 & 89 & 136 & 72 & 162 & 255 & - \\
\hline Calcium & - & 43 & 415 & 599 & 71 & 34 & 60 & - \\
\hline Chloride & - & 24 & 27 & 210 & 71 & 9 & 31 & - \\
\hline Iron & - & 43 & 1,760 & 61,100 & 73 & $<0.03$ & 0.22 & - \\
\hline Lead-210 & - & - & - & - & 58 & 0.0 & 2.8 & - \\
\hline Magnesium & - & 43 & 176 & 1,010 & 73 & 4 & 8 & - \\
\hline Manganese & - & 43 & 38.5 & 197 & 51 & $<0.01$ & 0.3 & - \\
\hline $\mathrm{pH}$ & - & 21 & 3.12 & 7.67 & 73 & 7.5 & 9.9 & - \\
\hline Potassium & - & 43 & 5.5 & 79.1 & 73 & 6 & 17 & - \\
\hline Sodium & - & 43 & 129 & 5,220 & 73 & 52 & 103 & - \\
\hline Sulfate & - & 16 & 6,950 & 230,000 & 71 & 51 & 88 & - \\
\hline TDS & - & 10 & 23,400 & 63,100 & 71 & 280 & 417 & - \\
\hline
\end{tabular}

${ }^{a}$ Nondetects, reflecting inflated detection limit due to matrix interference, were removed from database for calculations.

bBackground based on data collected during the period February 1988 through April 1992 from wells GUN-08-0609, -0610, -0626, $-0630,-0632,-0634,-0635,-0637,-0638$, and -0639 , and during February 1991 through October 1995 from wells GUN-08-0663, -0703, -0704, -0708, -0716, and -0717 .

Observed maximum background greater than MCL.

'Proposed concentration limit set at contract-required detection limit.

Note: All units reported in milligrams per liter except radium-226 and -228 and net gross alpha which are reported in picocuries per liter.

$\mathrm{MCL}$ - maximum concentration limit. 


\subsection{SITE INSPECTIONS}

The DOE will conduct routine inspections of the Gunnison disposal site to detect progressive change caused by slow-acting natural processes and to identify potential problems before the need for extensive maintenance, repairs, or corrective action. Nonroutine inspections also will be conducted to follow up on reports of events or conditions that have affected or potentially could affect the disposal site. The DOE will compare the findings from these inspections to initial baseline conditions to identify any changes over time and to provide a basis for future inspections, repairs, and corrective actions.

Site inspections will be thoroughly documented. After each inspection, the DOE will prepare a report for the NRC that records the findings of the inspection and that clearly identifies any adverse impacts or threats to the disposal cell.

\section{$3.1 \quad$ INSPECTION FREQUENCY}

The DOE will inspect the Gunnison disposal site annually. The DOE may schedule more frequent inspections at any time should the need arise. For example, the DOE may schedule a separate inspection of site vegetation if the annual site inspection did not coincide with the general growing season. The DOE will notify the NRC of the inspection schedule.

\section{$3.2 \quad$ INSPECTION TEAM}

The inspection team will consist of a minimum of two inspectors qualified to inspect disposal cell integrity and make preliminary assessments of modifying processes that could adversely affect the disposal cell. A plant specialist may also participate in inspections to evaluate the adequacy of the revegetation at the disposal site.

Follow-up inspection teams will include one or more technical specialists in appropriate disciplines to assess the problem(s) under investigation. For example, a follow-up inspection by a plant specialist may be required to evaluate reports of significant plant growth on the rock cover or a soils scientist or geomorphologist may be needed to evaluate erosion processes.

\subsection{SITE INSPECTION PROCEDURES}

Before each inspection, inspectors will perform a readiness review. The longterm surveillance program guidance (DOE, 1996) contains information useful in preparing for inspections.

Site inspections will cover the disposal cell, the surrounding disposal site area, and the immediate off-site areas. Site inspections must be thorough enough to identify any significant changes or active modifying processes that could potentially adversely affect the disposal cell. Surveillance should be performed 
to identify unanticipated effects of modifying processes such as gully formation, slope erosion, changes to the rock cover, ephemeral drainage channel changes, and significant modifications by humans, animals, or plants. Site-specific concerns include future expansion of the Gunnison County landfill, and potential breaking down of erosion protection rock due to freeze-thaw effects.

Inspectors will evaluate the integrity of the disposal cell by walking a series of transects around the perimeter and over the rock cover. Sufficient transects, at approximately $150-\mathrm{ft}(46-\mathrm{m})$ intervals, must be walked so that the disposal cell is thoroughly covered and inspected. Diagonal transects of the topslopes will be made and the crest line will be walked. Additional transects will be walked along the sideslopes and rock apron. Transects along the entire length of the diversion ditch will be made to determine whether it is functioning as designed and can be expected to continue to function properly. Inspectors will review transect paths from previous inspections and make efforts to vary the path of transects from one inspection to the next to ensure small anomolies are not overlooked. The sample inspection checklist (DOE, 1996) lists items that should be examined during inspections. During transects over Types $B, C$, and D riprap, inspectors will check for evidence of potential deterioration (i.e., breakdown) of the larger rock particles, including cracking, spalling, or slabbing (along fracture planes).

Special care must be taken to avọid misinterpretation of as-placed conditions. As-placed riprap particles will have, to a minor degree, the characteristics listed above. The key in evaluating whether or not freeze-thaw is affecting the riprap will be progressive, future deterioration of representative particles (not just minor amounts of particles with as-placed defects). Any particles that previously appeared sound and intact that deteriorate over time will be reported and will be reinspected during future monitoring.

The disposal cell has a rock cover and there is no planned vegetation on the disposal cell. However, remedial action of the areas surrounding the disposal cell included revegetation with grasses. The area surrounding the disposal cell will be monitored to determine the success of the revegetation efforts. Inspectors also will inspect this area for evidence of erosion caused by wind, sheet wash, or changes in drainage patterns.

Site inspections also will monitor damage to or disturbance of permanent sitesurveillance features, ground water monitor wells, fencing, gate, and locks.

From inside the disposal site, inspectors will visually survey the area within a maximum of $0.25 \mathrm{mi}(0.40 \mathrm{~km})$ from the boundary of the disposal site for evidence of land-use changes that indicate increased human activity such as land development or new roads and paths. Inspectors will note the condition of and changes to site access roads, surrounding vegetation, and relevant geomorphic features like gullies or ephemeral drainage channels; potential impacts to the site will be noted. Off-site DOE monitor wells will be inspected until they are properly abandoned. 
All site inspections will be conducted in accordance with a DOE-approved safety and health plan.

\subsection{FOLLOW-UP INSPECTIONS}

DOE will conduct follow-up inspections to investigate and quantify specific problems found during a previous inspection, other DOE-initiated activity, or other confirmed reports of vandalism, intrusion, damage, or other significant threat to the disposal site. Notifications of severe rainstorms, flash floods, or unusual events such as tornadoes or earthquakes in the vicinity of the Gunnison site also can trigger follow-up inspections. Follow-up inspections will be conducted to determine whether processes currently active at or near the site threaten site security or stability and to evaluate the need for custodial maintenance, repair, or other corrective action. The scope of these follow-up inspections may be broad and similar in nature to routine site inspections or focused on specific areas of concern.

A follow-up inspection usually will begin with an on-site visit by technical specialists to confirm whether or not the disposal cell has been damaged or to determine the need for more definitive tests or studies. The DOE will schedule additional site visits if more data are needed to draw conclusions and to recommend repairs or corrective action.

\subsection{QUALITY ASSURANCE}

The DOE has developed and implemented a quality assurance plan (DOE, 1992c) for the site inspection program that meets the requirements of DOE Order 5700.6C. All site inspections will be conducted in accordance with this quality assurance plan.

\subsection{SITE INSPECTION DOCUMENTATION}

During site inspections, all activities and observations will be recorded and described using a site inspection checklist, site inspection map, photographs and photo log, and field notes. Documentary evidence of anomalous, new, or unexpected conditions or situations must describe developing trends and enable the DOE to make decisions concerning follow-up inspections, custodial maintenance, and corrective action. The DOE will prepare a site inspection report documenting the findings and recommendations from each field inspection.

\subsubsection{Site inspection checklist}

The sample site inspection checklist (DOE, 1996) is a guide for the inspectors to prepare for and conduct site inspections. Inspectors will prepare a site-specific checklist that addresses the features to be inspected and monitored at the Gunnison disposal site. All checklist items should be completed. Annotations 
-... should be made on the checklist to add more detailed information. All entries must be clearly stated and legible because the completed checklist becomes part of the permanent field record of the inspection. Upon completion of the inspection, the lead inspector must sign a statement certifying the scope of the inspection.

After each inspection is complete, the checklist may be revised, if necessary, to include new information or to delete items that are no longer pertinent.

Revisions to the checklist will be documented in the inspection report.

\subsubsection{Site inspection maps}

Plate 1 will serve as the baseline for preparing the site inspection map. The inspection team will annotate copies of the site inspection map during site inspections. The annotated site inspection map must include the following information:

- Inspection traverses.

- Photographic locations.

- Locations and descriptions of any new, anomalous, or unexpected features.

- Features identified during previous inspections for observation or monitoring.

- Inspection date and type of inspection.

\subsubsection{Site inspection photographs}

A photographic record of the site inspection must be maintained. Site conditions should be documented by ground photographs to record developing trends and to enable the DOE to make decisions concerning additional inspections, custodial maintenance or repairs, or corrective action. If possible, any site feature or condition requiring inspectors to make a written comment, explanation, or description will be photographed. A site inspection photo log will be used to record the photographs. A separate photo log should be completed for each roll of exposed film, with an entry for each photograph.

At a minimum, the site features listed in the long-term surveillance guidance (DOE, 1996) should be documented with photographs during site inspections. In addition, any new or potential problem areas identified during a site inspection must be well documented with photographs. All site inspection photographs, as well as all corresponding photo log forms, will be maintained in the permanent site file.

\subsubsection{Field notes}

The inspection team will use field notes to record observations made during the . inspection but not recorded on the inspection checklist or inspection map. The field notes will become part of the permanent site file. 


\subsubsection{Site inspection report}

After every site inspection, the DOE will prepare a site inspection report that discusses scope of the inspection, observations made, and conclusions drawn from the inspection. At a minimum, the inspection report will include

- Description of the site conditions.

- Completed site inspection checklists and any relevant supporting documentation, including names and qualifications of the field inspectors.

- Site inspection map and other relevant drawings, maps, or figures.

- Inspection photographs and photo logs.

- Conclusions and recommendations for follow-up inspections, custodial maintenance, or repairs, if required.

- Custodial maintenance or repair report and certification, if any was performed.

If new conditions requiring monitoring or immediate action are discovered during the inspection, the inspection report will detail any observed modifying features and will include a description of the problem, relevant measurements and photographs, and an impact assessment. The description of the modifying process will include information such as the following:

- Extent of area affected.

- Number, spacing, and size of features (e.g., gullies).

- Locations and patterns of occurrence.

- Species, location, and density of volunteer plant growth.

Evidence of deliberate and repeated human intrusion such as cover removal, extensive vandalism to signs and monuments, or the presence of well-established trails will be described in detail. All signs of vandalism will be noted since evidence of continued vandalism may indicated the need to implement more active measures to control site access.

The results of all follow-up inspections shall be documented in written reports. Other appropriate documentation such as photographs, measurements, and drawings shall be included. At a minimum, a follow-up inspection report must include the following:

- Description of the problem and preliminary assessment of impact.

- Conclusions and recommendations for custodial maintenance, repair, or corrective action required. 
- Assessment data, photographs, and supporting documentation.

A copy of all site inspection reports and supporting documentation will be maintained in the permanent site file. 


\subsection{GROUND WATER MONITORING}

The DOE evaluated the need for ground water monitoring at the Gunnison disposal site in accordance with the licensing regulations at $10 \mathrm{CFR} \$ 40.27(\mathrm{~b})(2)$, the ground water protection standards at 40 CFR Part 192, Subparts A and C, and the DOE's long-term surveillance program guidance (DOE, 1996). POC monitoring is required for the long-term surveillance program at the Gunnison disposal site to comply with the ground water protection standards at 40 CFR $\$ 192.03$ to demonstrate disposal cell performance.

\subsection{GROUND WATER MONITORING PLAN}

The ground water protection monitoring plan includes sampling and analyzing ground water from a series of monitor wells downgradient from the disposal cell at the POC and upgradient or crossgradient from the disposal cell as background (Section 2.6.1). The long-term monitoring strategy is to sample the direct monitor well network at prescribed intervals for water levels and a set of screening parameters. Should screening monitoring indicate that there is a potential release from the disposal cell, evaluative ground water monitoring will be conducted to determine the nature of the exceedance. The direct monitor well network and performance monitoring frequency are discussed below. Potential indirect monitoring techniques that may be used, if it is determined they are necessary, are discussed in Section 4.1.6.

\subsubsection{Direct ground water monitoring network}

Ground water samples will be collected from six POC wells downgradient of the disposal cell. Sampling will be performed to measure ground water quality and static water levels at the POC, directly downgradient of the disposal cell in the uppermost aquifer. The six POC wells will be located approximately $50 \mathrm{ft}$ $(15 \mathrm{~m})$ from the disposal cell (Plate 1). Placement of the POC monitor wells optimizes early detection of any hazardous constituents released in the uppermost aquifer without disturbing the design components of the cell. The POC wells will be installed into the uppermost aquifer.

Ground water quality and water level data will also be monitored in two background wells, wells GUN-08-0609 upgradient and well GUN-08-0716 crossgradient from the disposal cell. These wells are screened in the same aquifer as the POC wells and at approximately the same depth. The background well will be sampled at the same frequency as the POC wells and will be monitored for the same constituents. Water levels will also be measured in 8 wells away from the disposal cell to monitor potential changes in regional hydrologic conditions (Section 2.6.1).

\subsubsection{Sampling frequency}

The schedule for sampling takes into account such factors as background ground water quality, the geochemistry of the tailings pore fluid solution, horizontal and 
vertical ground water flow rates, the possibility of seasonal variations in ground water, and risk to human health and the environment. Ground water levels will be measured before each well is sampled. Monitor wells at the Gunnison disposal cell have been sampled annually or semiannually since 1988 . During construction of the cell and placement of tailings, monitor wells were sampled semiannually (in the early summer and fall).

The long-term surveillance monitor well network will be sampled according to the sampling schedule in Table 4.1.

Table 4.1 Sampling schedule for the monitor well network at the Gunnison, Colorado, disposal site

\begin{tabular}{|c|c|c|}
\hline $\begin{array}{l}\text { Years after POC } \\
\text { well completion }\end{array}$ & $\begin{array}{c}\text { Number of sampling } \\
\text { events }\end{array}$ & Time of sampling \\
\hline 1 & 2 & Fall and early summer \\
\hline 2 & 1 & Early summer \\
\hline 3 & 1 & Early summer \\
\hline 4 & 1 & Early summer \\
\hline 5 & 1 & Early summer \\
\hline $10^{a}$ & 1 & Early summer \\
\hline
\end{tabular}

The monitor well network will be sampled twice in the first year after POC well completion (fall, 1996 and early summer, 1997). These two sampling rounds during the first year will determine if water quality in each POC well is stable and representative of baseline conditions. Sampling will be conducted in the fall and early summer to maintain a consistent record in the historical database.

Sampling will be conducted annually the second through fifth years (1998 through 2000) after POC well installation. These data will establish a baseline for each POC well. It is expected that each POC well will be representative of one of the two types of ground water observed in background. Sampling will be conducted in the early summer to coincide with the expected time of greatest potential ground water recharge.

A sampling frequency of once every 5 years is recommended, starting with sampling on the tenth year following POC well installation. These sampling frequencies are recommended at the disposal cell for the following reasons: 
- The average water level in the uppermost aquifer beneath the disposal cell is approximately $110 \mathrm{ft}(34 \mathrm{~m}$ ) below land surface (DOE, 1992b),

- Background water quality in the uppermost aquifer beneath the disposal cell is well established (Section 2.6.2),

- The disposal cell design minimizes infiltration through the cover; the tailings were placed into the disposal cell at a moisture content designed to produce almost no transient drainage (DOE, 1992b),

- Geochemical investigations conducted during preparation of the RAP (DOE, 1992b) determined that geochemical characteristics of the foundation materials are favorable in attenuating seepage of hazardous constituents in tailings from the base of the disposal cell, and

- Ground water use is limited in the disposal cell vicinity. Only one private well is known to be located downgradient of the disposal cell (DOE, 1992b). This well is located approximately $7500 \mathrm{ft}(2390 \mathrm{~m})$ from the disposal cell. Using the estimated ground water velocity within the Tertiary gravel aquifer of approximately $7 \mathrm{ft}$ per year $17 \times 10^{-6} \mathrm{~cm}$ per second) (Calculation No. GUN-05-90-14-07-02), it would take over 1000 years for any potential contamination from the disposal cell to reach this well.

This frequency may be changed, upon approval from the NRC, based on sitespecific conditions and the effectiveness of disposal cell performance as determined through the ongoing monitoring program.

\subsubsection{Ground water monitoring team}

Water samples will be collected by a team consisting of, at a minimum, two water sampling technicians. The technicians will be knowledgeable in the general principles of ground water sampling techniques. Personnel will be required to follow a set of standard operating procedures or industry accepted standards, such as American Society for Testing and Materials standards, under strict quality assurance/quality control standards designed to produce ground water analyses that are defensible and representative of ground water conditions. Collected data will be evaluated by a technical specialist experienced in the interpretation of hydrogeological data.

\subsubsection{Screening monitoring and exceedance validation}

During the established ground water monitoring period, screening monitoring will be conducted to observe possible changes in ground water quality and to assess compliance with the ground water protection standards. Screening monitoring includes routine water-quality data collection, data evaluation, and possible resampling. It also includes analyzing constituents that are indicative of general water quality and hazardous constituents that are reliable indicators of 
contamination (Table 4.2). General water quality indicators include $\mathrm{pH}$, electrical conductivity, temperature, alkalinity, oxidation-reduction potential, and major anions and cations. These data provide general information for interpreting potential changes in ground water quality. Screening parameters indicative of contamination are those that 1) are known to be present in the tailings solutions at levels statistically greater than background levels, 2) are present at much higher levels in the tailings solutions than in background, 3) display low variability in background, and 4) are mobile in the ground water environment. The parameter that best meets these criteria is uranium.

Exceedances in concentration limits for uranium are evaluated on a well-by-well basis. If the screening monitoring action level for uranium listed in Table 4.2 is exceeded, the well will be resampled within 1 year for all screening monitoring parameters listed in Table 4.2. If the resampling indicates a second exceedance or if changes in other monitored constituents or wells are observed that clearly support the inference that contamination from the disposal cell is reaching ground water in excess of the deșign standards, then the monitoring program will enter into the evaluative monitoring phase. The DOE will notify the NRC of this event and that an evaluative monitoring work plan is being prepared.

\subsubsection{Evaluative monitoring}

When sampling, evaluating, and resampling during screening monitoring does not eliminate the disposal cell as the cause for a water-quality exceedance, evaluative ground water monitoring, additional evaluation, and fieldwork may be required. The purpose of evaluative monitoring is to determine with greater surety whether the disposal cell is directly or indirectly contributing to the observed exceedances, and if so; to isolate the probable contributing source and assess the current and potential future impacts to ground water.

Evaluative ground water monitoring will involve sampling ground waters from POC and possibly other wells, and analyzing for the entire suite of hazardous constituents identified in Table 2.3 to determine if any hazardous constituents exceed the proposed concentration limits. Data and fieldwork will be evaluated further to determine if the disposal cell is the cause of an exceedance and if so, its nature and extent. The DOE will submit the evaluative monitoring work plan to the NRC for review prior to initiating the evaluative monitoring program. Additional details concerning an evaluative monitoring work plan are presented in the long-term surveillance program guidance (DOE, 1996). 
Table 4.2 Parameters to be measured during screening monitoring at the Gunnison, Colorado, disposal site

Parameter

Proposed screening monitoring action level

Indicator parameter for detecting ground water contamination

Uranium

$0.027^{\mathrm{a}}$

Field parameters for monitoring ground water quality

Alkalinity

None

Oxidation-reduction potential

None

$\mathrm{pH}$

None

Specific conductivity

None

Temperature

None

Major anions and cations for monitoring ground water quality

Calcium

None

Chloride

None

Iron

None

Magnesium

None

Manganese

None

Potassium

None

Sodium

None

Sulfate

None

TDS

None

${ }^{a}$ Proposed action level is in milligrams per liter and is based on maximum observed background value. 


\subsubsection{Indirect monitoring}

As stated above, the DOE will directly monitor ground water at the disposal site. If screening and evaluative monitoring indicate a change in ground water quality attributable to the disposal cell design, the need for indirect monitoring will be assessed.

If evaluative monitoring indicates the performance of the disposal cell is the cause of an exceedance, it may be necessary to monitor the cover, the tailings, the subsoils, or a combination of components. Some indirect methods that may be applicable to monitoring changes in moisture content in the disposal cell include core sampling to determine gravimetric water content, neutron moisture probe monitoring, time-domain reflectometry, heat dissipation probes, or crosshole topography. Any indirect monitoring instrumentation that may be required will be installed in accordance with the appropriate standard operating procedures or best management practices.

Specific monitoring strategies and instrumentation will be selected in consultation with the NRC.

\subsection{DATA VALIDATION AND QUALITY ASSURANCE}

All aspects of the ground water monitoring plan will be conducted in accordance with accepted industry quality assurance practices, including DOE directives in DOE Order $5700.6 \mathrm{C}$, and will be consistent with EPA ground water monitoring guidance (EPA, 1986).

The DOE has established standard operating procedures for monitor well installation and development, water and soil sampling, sample preservation and transport, field procedures, chain-of-custody samples for laboratory analyses, acquisition protocols, and validating and managing analytical data. All aspects of ground water monitoring are conducted in accordance with these procedures, which are updated regularly to reflect changes in industry standards, best management practices, and guidance from the DOE or EPA.

\subsection{GROUND WATER MONITORING DOCUMENTATION}

Hard copies of reports of ground water data collected during the long-term surveillance monitoring program will be stored in the permanent site file; the ground water data will also be stored in the DOE ground water quality database along with historical ground water quality data for the Gunnison site.

Once every 5 years, the DOE will describe the data and results of the ground water monitoring program in an evaluation report to the NRC. The 5-year report will include the following information:

- Water quality data, water level data, and other data collected during the reporting period. 
- A table comparing water quality indicators to concentration limits.

- A summary of exceedances of concentration limits and the exceedance validation criteria.

- A summary of all resampling, evaluative monitoring, indirect monitoring, or corrective action required during the reporting period.

- A discussion of significant trends or anomalies in the water quality, other data, or changes in the local hydrologic setting.

- A discussion of new wells or indirect monitoring stations that were installed, including the rationale for their installation, and all completion data.

- All completed field and laboratory forms. 


\subsection{CUSTODIAL MAINTENANCE OR REPAIR}

The DOE does not plan to conduct routine maintenance at the Gunnison disposal site. However, the DOE will perform needed custodial maintenance or repair as determined from site inspections. The DOE will prepare a statement of work that will include qualifications of the maintenance/repair contractor and certify all custodial maintenance and repair work performed at the Gunnison disposal site.

Unscheduled custodial maintenance or repair required at the Gunnison disposal site may include the following:

- Repairing or replacing deteriorated or vandalized warning signs, fencing, gate, locks, and monitor well caps.

- Removing volunteer plant growth from riprap-covered areas.

- Reseeding areas surrounding the disposal cell.

If repairs are needed to address problems that may affect the integrity of the disposal cell or compliance with 40 CFR Part 192, the NRC must approve the recommended action in advance. Such action will be treated as a corrective action (see Section 6.0).

After the work is completed, the maintenance/repair contractor must submit written verification of the completed work. The DOE will inspect the site, as necessary, and review the report before certifying that all work is completed in accordance with all required specifications.

The annual report to the NRC must include the following information on unscheduled maintenance or repair:

- Work order, purchase order, or statement of work.

- Contractor documentation of work completion.

- DOE certification of work completion.

Copies of all records, reports, and certifications will be included in the permanent site file. 


\subsection{CORRECTIVE ACTION}

Site inspections and ground water monitoring are designed to identify problems at the developmental stage. Examples of conditions that might trigger corrective action are

- Surface rupture or subsidence of the disposal cell.

- Development of rills or gullies or slope instability on the disposal cell.

- Deterioration of the erosion protection rock on the disposal cell.

- Exceedance of ground water concentration limits at POC wells.

- Seepage originating from the disposal cell.

- Gully development on or immediately adjacent to disposal site property that could affect the integrity of the disposal cell.

- Damage to the cell cover or disposal site property from natural catastrophic events or vandalism.

- Evidence of hazardous material spills near monitor wells.

- Damage to the disposal cell cover from deep-rooted plant growth.

The DOE will evaluate the factors that caused the problem and identify actions to mitigate the impact and prevent recurrence. An on-site inspection or preliminary assessment would include, but is not limited to, the following:

- Identifying the nature and extent of the problem.

- Reevaluating germane engineering design parameters.

- Establishing a data collection and/or evaluative monitoring program to determine or confirm the cause of an exceedance of ground water concentration limits.

When a potential problem is identified, the DOE will submit a preliminary assessment report to the NRC for review no more than 60 days after the problem is identified. The preliminary assessment report will evaluate the problem and recommend the next step (e.g., immediate action or continued evaluation). After the NRC reviews the report and recommendations, the DOE will develop a corrective action plan for NRC approval. Once the NRC approves the corrective action, the DOE will implement the plan. In some cases, corrective action could include temporary emergency measures taken prior to the completion of the normal approval process. In cases where the corrective action is in response to an exceedance of the ground water standards, the plan will include a 
monitoring plan to demonstrate the effectiveness of the corrective action, which the DOE will implement after consultation with the NRC.

NRC regulations do not stipulate a time frame for implementing corrective action.

However, 40 CFR $\$ 192.04$ requires that a corrective action program begin within 18 months after a finding of an exceedance in established ground water concentration limits. The DOE does not consider assessing the extent of a problem and developing a corrective action plan to be initiation of the corrective action program.

In addition to the preliminary assessment report, the DOE may prepare progress reports on each corrective action while it is under way or under evaluation.

After corrective action is complete, the DOE will certify all work and submit a certification statement and supporting documentation to the NRC for review and concurrence. A copy of the certification statement will become part of the permanent site file, as will all reports, data, and documentation generated during the corrective action. 


\subsection{EMERGENCY NOTIFICATION AND RESPONSE}

To ensure the timely investigation of potential problems affecting the disposal cell, the DOE has requested notification from federal, state, and local agencies of discoveries or reports of any purposeful intrusion or damage at the disposal site as well as the occurrence of earthquakes, tornadoes, or floods in the disposal site area.

The DOE is negotiating notification agreements with the Gunnison County Sheriff's Office, the U.S. Geological Survey's National Earthquake Information Center, and the Colorado area office of the National Weather Service (Attachment 2). These agreements will trigger notification of the more probable occurrences that could cause an emergency response. In addition, the DOE 24-hour phone number is posted on the site entrance sign so the public can notify the DOE if problems are discovered.

The nature of the occurrence and the amount of first-hand knowledge available will determine the DOE's response. If an emergency situation poses an immediate threat to the public, the DOE will notify individuals who may be affected and appropriate federal, state, and local agencies, including the NRC. The DOE will take appropriate response action and advise the affected individuals of precautions that should be taken.

In all cases, the notification, response, and any follow-up activities shall be documented. This documentation will become part of the permanent site file. Discussions of emergency notifications and responses also will be included in the annual site report to the NRC. 


\subsection{RECORD KEEPING AND REPORTING}

The DOE will maintain a permanent site file containing site inspection reports and other supporting documentation of long-term surveillance program activities. The information placed in the site file will include:

- Documentation of disposal site performance.

- Demonstration that licensing provisions were met.

- Information needed to forecast future site surveillance and monitoring needs.

- Reports to stakeholders regarding disposal cell integrity.

After the site is brought under the general license, the DOE will compile copies of site documentation required by the long-term surveillance program guidance (DOE, 1996) for the Gunnison disposal site permanent site file. Copies of all deeds, custody agreements, and other property documents will be kept in the site file.

The surveillance and maintenance documentation identified in other sections of this LTSP will be maintained by the DOE and become part of the permanent site file. The DOE will update the site file as necessary after disposal site inspections, maintenance activities, or corrective actions are complete. These records will be handled in accordance with DOE directives to ensure their proper handling, maintenance, and disposition. The archival procedures set forth in 41 CFR Part 101 and 36 CFR Parts 1220-1238 (Subchapter B) will be followed. All information will be available for NRC and public review.

The DOE will prepare an annual report documenting the results of site inspections and any other activities conducted in conjunction with the long-term surveillance program (Section 3.6.5). In accordance with 10 CFR Part 40 requirements, the annual report will be submitted to the NRC no more than 90 days after the date of the last UMTRA Project site inspection for that calendar year. This submittal will also include reports on any follow-up inspections and custodial maintenance or repairs performed during the year.

Following any inspection where unusual damage or disruption is discovered at the Gunnison disposal site, a preliminary report assessing the impact must be submitted to the NRC within 60 days of the initial discovery of the problem. If maintenance or repair or corrective action is warranted, the DOE will notify the NRC. The NRC will receive a copy of corrective action plans and each corrective action progress report, or the reports will be attached to the annual report.

In addition to the annual inspection report, every 5 years the DOE will submit an evaluation report to the NRC with the results of the ground water monitoring program.

The DOE will provide copies of inspection reports and other reports generated under the long-term surveillance program to the state of Colorado as dictated in their cooperative agreement. 


\subsection{REFERENCES}

Davis, S. N., and R. DeWiest, 1966. Hydrology, John Wiley \& Sons, Inc., New York, New York.

DOE (U.S. Department of Energy), 1996. Guidance for Implementing the Long-Term Surveillance Program for UMTRA Project Title / Disposal Sites, DOE/AL-62350189, Rev. 0, prepared for the U.S. Department of Energy, Environmental Restoration Division, UMTRA Project Team, Albuquerque, New Mexico.

DOE (U.S. Department of Energy), 1994. Baseline Risk Assessment of Ground Water Contamination at the Uranium Mill Tailings Site Near Gunnison, Colorado, DOE/AL-62350-57D, Rev. 1, prepared for the U.S. Department of Energy, UMTRA Project Office, Albuquerque Operations Office, Albuquerque, New Mexico.

DOE (U.S. Department of Energy), 1992a. Environmental Assessment of Remedial Action at the Gunnison Uranium Mill Tailings Site Near Gunnison, Colorado, DOE/EA0376, prepared for the U.S. Department of Energy, UMTRA Project Office, Albuquerque Operations Office, Albuquerque, New Mexico.

DOE (U.S. Department of Energy), 1992b. Remedial Action Plan and Site Conceptual Design for Stabilization of the Inactive Uranium Mill Tailings Site at Gunnison, Colorado, UMTRA-DOE/AL-050508.0000, prepared for the U.S. Department of Energy, UMTRA Project Office, Albuquerque Operations Office, Albuquerque, New Mexico.

DOE (U.S. Department of Energy), 1992c. Long-Term Surveillance and Maintenance Program Quality Assurance Program Plan, P-GJPO-152, prepared by Chem Nuclear Geotech, Inc., for the U.S. Department of Energy, Grand Junction Projects Office, Grand Junction, Colorado.

EPA (U.S. Environmental Protection Agency), 1992. Addendum to Interim Final Guidance Statistical Analysis of the Ground-Water Monitoring Data at RCRA Facilities, Office of Solid Waste, U.S. Environmental Protection Agency, Washington, D.C.

EPA (U.S. Environmental Protection Agency), 1986. RCRA Ground Water Monitoring Technical Enforcement Guidance Document, OSWER Directive 9950.1, Office of Solid Waste and Emergency Response, U.S. Environmental Protection Agency, Washington, D.C.

Freeze, R. A., and J. A. Cherry, 1979. Ground Water, Prentice-Hall, Inc., Englewood Cliffs, New Jersey. 
MK-ECE (Morrison Knudsen Corporation - Engineering, Construction, \& Environmental Group), 1995. UMTRA Project, Gunnison, Colorado, Surveillance and Maintenance Subcontract Documents - Final Design for Review, prepared by MKECE for the U.S. Department of Energy, Environmental Restoration Division, UMTRA Project Team, Albuquerque, New Mexico.

MK-F (Morrison Knudsen-Ferguson), 1996. Gunnison, Colorado, Draft Completion Report, prepared by MK-F for the U.S. Department of Energy, Environmental Restoration Division, UMTRA Project Team, Albuquerque, New Mexico.

\section{CODE OF FEDERAL REGULATIONS}

10 CFR Part 40, Domestic Licensing of Source Material, U.S. Nuclear Regulatory Commission.

36 CFR Parts 1220-1238, National Archives and Records, Subchapter B - Records Management, National Archives and Records Administration.

40 CFR Part 192, Health and Environmental Protection Standards for Uranium and Thorium Mill Tailings, U.S. Environmental Protection Agency.

41 CFR Part 101, Federal Property Management Regulations, General Services Administration.

\section{DOE ORDERS}

Order 5700.6C, Quality Assurance, 21 August 1991, U.S. Department of Energy, Washington, D.C.

\section{UNITED STATES CODE}

42 USC $\S 7901$ et seq., Uranium Mill Tailings Radiation Control Act, 8 November 1978. 
ATTACHMENT 1

SITE REAL ESTATE INFORMATION 


\section{SITE REAL ESTATE INFORMATION}

The Uranium Mill Tailings Radiation Control Act (UMTRCA) of 1978, as amended, requires the Secretary of Energy to permanently acquire lands needed to carry out the purposes of the UMTRCA. The area the U.S. Department of Energy (DOE) selected for the Gunnison disposal site was located on public land being administered by the U.S. Department of the Interior's Bureau of Land Management (BLM).

\section{TRANSFER OF ADMINISTRATION OF THE DISPOSAL SITE}

Under the authority vested in the Secretary of the Interior by the UMTRCA, the BLM transferred administration of approximately 115 acres (ac) (47 hectares [ha]) of public land in Gunnison County, Colorado, to the DOE to use for the Gunnison disposal site via Public Land Order 6931. As a result of this permanent transfer, the land is longer subject to the operation of the general land laws, including the mining and mineral leasing laws. The transfer of the land vested in the DOE the full management, jurisdiction, responsibility, and liability for the land and all activities conducted thereon, except that the Secretary of the Interior retains the authority to administer any claims, rights, and interests in the land established before the effective date of the transfer.

\section{LEGAL DESCRIPTION}

Public Land Order 6931 was published in the Federal Register on 15 June 1992, the effective date of the transfer. The attached copy of the order (57 FR 26607) contains a legal description of the land transferred to the DOE.

The final disposal site will only comprise approximately 92 ac ( 37 ha) of the original 115 ac (47 ha). The DOE will include the legal description of the final disposal site boundaries in this attachment after the final site survey is completed. 
CHAPTER 101-FEDERAL PROPERTY MANAGEMENT REGULATIONS

SUBCHAPTER G-AVIATION, TRANSPORTATION, AND MOTOR VEHICLES

Appendix to Subchapter G-Temporary Regulations

[FPMR Teenp. Reg. G-54; Supplement 1] April 16, 1992.

Use of Contractor for Express Small Package Transportation

1. Purpose. This supplement extends the expiration date of FPMR Temporary

Regulation G-54.

2. Effective date. This supplement is effective Januery 15, 1992

3. Expiration date. This rupplement expires November 15, 1992, unless sooner canceled or revised.

4. Background. FPMR Temporary

Regulation G-54, deted juły $9,1991$.

prescribes policies and procedures applicable

to Federal agencies when transportation of

express small packages from, to, and

between specified locations in the United

States (inctuding Alaska and Hawaii) and

Puerto Rico, is required and the contrector or

its agent provides next day service. This

regulation also identifies the contractor and

the effective rates.

5. Explenation of change. The expiration

date in paragraph 3 of FPMR Temporaty

Regulation G-5A is extended to November 15 ,

1992.

Richard G. Austin,

Administrator of Ceneral Services.

[FR Doc 82-13747 Filed 6-12-82; 8:45 am] ILUHA COOE c3e20-24-i

\section{DEPARTMENT OF THE INTERIOR}

\section{Bureau of Land Management}

\section{CFR Publle Land Order 6930}

[NM-940-\$214-10; NHNM 81795] .

Withdrawal of Public Land for Wild Rivers Recreation Area; New Mexico

AGEнCY: Bureau of Land Management, Interior.

ACtrok: Public Land Order.

sUMkaRY: This order withdraws 4,979.94 ecres of public land from surfece entry and mining for a period of 20 years for the Bureau of Land Management to protect the Wild Rivers Recreation Area near the vicinity of Cerro, New Mexico. The land has been and remains open to mineral leasing.

EFFECTIVE DATE June 15, 1992.

FOR FURTHER INFORHATIOH CONTACT:

Clarence F. Hougland, BLM New Mexico

State Office, P.O. Box 27115, Santa Fe,

New Mexico 87502-7115, 505-438-7593.
By virtue of the authority vested in the Secretary of the Interior by section 204 of the Federal Land Policy and Management Act of 1976, 43 U.S.C. 1714 (1988), it is ordered as follows:

1. Subject to valid existing rights, the following described public land is hereby withdrawn from settlement, sale, location, or entry under the general land laws, including the United States mining laws (30 U.S.C. ch. 2 (1988)), but not . from leasing under the mineral leasing laws, to protect the Wild Rivers

Recreation Area:

New Mexico Principal Meridien

T. 28 N. R. 12 E!

Sec 3 , lots 1 to 4 , inclusive, and $S 32 N z_{2}$;

Sec. 4 , lots 1 to \&, inclusive, S/2N1/2, and SH:

Sec. 5, lots 1 to 1 , inclusive, S\%/2N $/ 2$, $N 1 / 2 W 1 / 4$, and SE1/4;

Sec. 6 , lot 1 , and SE $1 / 6 N E 1 / 4$;

$\operatorname{Sec} 8, E / 2 E / / 2$ and $E / 2 W / / 2 E y_{2} ;$

Sec. 9. NW/4NE $1 / 4, W / 2 S W 1 / 4 N E 1 / 4$.

$W y_{2} S W y_{4}, W y_{2} E z_{2} S W y_{4}$, and NEY/ANE $1 / 5 W 344 ;$

Sec. 16, NW1/NW1/4:

Sec 17, E/2NEY/4 and EKWW/2NE\%/

T. $29 \mathrm{~N}_{n} \mathrm{R} .12 \mathrm{E}$

Sec. 22, $W / / 2 S W / / 4$ and $W / 2 E / 2 S W H / 4$

Sec. 20, WHzWHEH and $W \psi_{2}$ :

$\operatorname{Sec} 28 ;$

Sec. 29. lots 1 to 8, inclusive, E\%2E - SE\%/SE\%NW\%, E1/2NEKSW/4, and $S E Y S W H_{;} ;$

Sec. 31, SEMSEE $/ 4 ;$

Sec. 32, E/2NW//NWW/4;

Sec 33:

Sec. 34, WH/2.

The area described contains 4.979.94 acres in Taos County.

2. The withdrawal made by this order does not alter the applicability of those public land laws governing the use of the land under lease, license, or permit, or governing the disposal of its mineral or vegetative resources other than under the mining laws.

3. This withdrawel will expire 20 years from the effective date of this order unless, as a result of a review conducted before the explration date pursuent to section 204(f) of the Federal Land Policy and Manegement Act of 1976, 43 U.S.C. 1714(f) (1988), the

Secretary determines that the withdrawal shall be extended.

\section{Dated: June 3, 1992.}

Dave O'Neal, Assistant Secretary of the Interior.

[FR Doc 82-13988 Filed 6-12-92; 8:45 am]

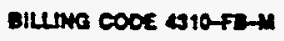

43 CFR Public Land Order 6931

[co-930-4920-10-4329; coc-53301]

Transfer of Public Land for the Gunnison Disposal Site; Colorado

AGENCY: Bureau of Land Management, Interior.

action: Public Land Order.

summary: This order permanently transfers 115 acres of public land to the Department of Energy in accordance with the terms of the Uranium Mill Tailings Remedial Action Amendments Act of 1988.

EFFECTIVE DATE JUnE 15, 1992.

FOR FURTHER INFORMATION CONTACT: Doris E. Chelius, BLM Colorado State Office, 2850 Youngfield Street, Lakewood, Colorado 80215-7076, 303239-1706.

By virtue of the authority vested in the Secretary of the Interior by the Uranium Mill Tailings Radietion Control Act of 1978 (42 U.S.C. 7916 (1988)), it is ordered as follows:

1. Subject to valid existing rights, the following described public land is hereby permanently transferred to the Department of Energy, and as a result of this transfer, the land is no longer subject to the operation of the general land laws, including the mining and mineral leasing laws, for the Gunnison Disposal Site:

Now Mexico Principal Meridian

T. 49 N. R. 1 E.

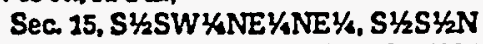

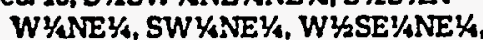
S/2SE $1 / 6 N E 1 / 4 N W 1 / 4, N E 1 / S E 1 / 4 N W 1 / 4$, N//2SEYSE $/ / 4 N W 1 / 4, S E 1 / 4 E 1 / 4 S$

B $1 / 4 N W y_{4}, N E y_{4} N E y_{4} N E 1 / 4 W y_{4}$ N/2NW/4NE $\% S E Y 4$, and N/2N/2N WHSEY4.

The area described contains approximately 115 acres of public lend in Gunnison County.

2. The transfer of the above-described land to the Department of Energy vests in that Department the full management jurisdiction, responsibility, and liability for such land and all activities conducted thereon, except as provided in paragraph 3.

3. The Secretary of the Interior shall retain the authority to administer any existing claims, rights, and interests in this land established before the effective date of the transfer.

Dated: June 3, 1992.

Dave ONeal,

Assistont Secretory of the Interior.

[FR Doc 92-13985 Filed 8-12-92; 8:45 am] ILUNO COOE 4310-NO-N 


\section{ATTACHMENT 2}

\section{AGENCY NOTIFICATION AGREEMENTS}


Rick Murdie

Gunnison County Sheriff's Office

200 E. Virgina Avenue

Gunnison, Colorado 81230

Dear Sheriff Murdie:

The U.S. Department of Energy (DOE) Uranium Mill Tailings Remedial Action Project is requesting notification in the event of any unusual activities or events in southeast Gunnison County, Colorado, around the DOE's Gunnison uranium mill tailings disposal site. The site is located approximately six miles southeast of Gunnison, Colorado, in Township 49 North, Range 1 East, Section 15, just southwest the Gunnison County Landfill. The disposal site is reached by taking County Road 42 (Sixmile Lane) south from U.S. Highway 50 to BLM Route 3068 then proceeding west about one mile (see enclosed map).

The purpose of the notification request is to assist the DOE in monitoring and maintaining the integrity of the Gunnison disposal site and to ensure public safety.

If during the course of routine activities, anything out of the ordinary that could potentially impact the site is observed by your staff or reported to your office, we would appreciate notification to the DOE Grand Junction Projects Office's 24-hour phone line at (970) 2486070.

If the notification request discussed above is agreeable to you, please sign and return the attached reply letter for our records as soon as possible.

Should you have any questions, please contact me at (505) 845-4865. Thank you for your attention in this matter.

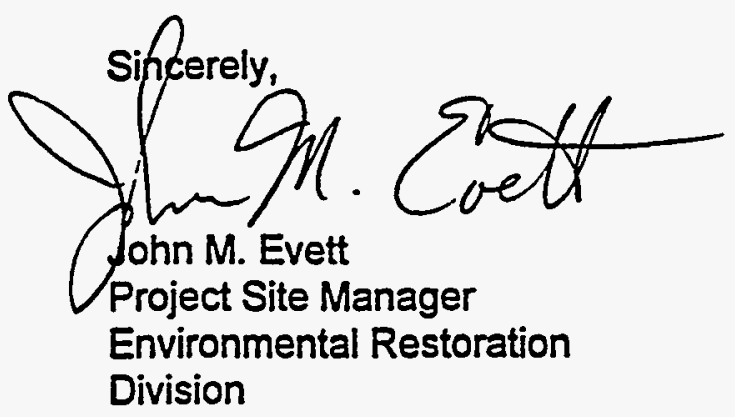

Enclosures

cc w/o enclosures:

J. Virgona, GJPO 
John M. Evett

Project Site Manager

Environmental Restoration Division

U.S. Department of Energy

P.O. Box 5400

Albuquerque, NM 87115

Dear Mr. Evett:

This letter is to concur with the U.S. Department of Energy (DOE) request for notification as set forth in the DOE's letter. As requested in your letter, this office will contact the DOE's Grand Junction Projects Office at (970) 248-6070 if any unusual event or anomaly is observed or reported at or around the DOE's Gunnison disposal site, Gunnison County, Colorado.

Sincerely,

Rick Murdie

Gunnison County Sheriff

cc: J. Virgona, GJPO 


\section{APR 0319.85}

\section{Larry Mooney}

Area Manager

National Weather Service Office

10230 Smith Road

Denver, Colorado 80239

Dear Mr. Mooney:

The U.S. Department of Energy (DOE) Uranium Mill Tailings Remedial Action Project is requesting notification in the event of issuance of flash flood or tomado warnings in southeast Gunnison County, Colorado. We would appreciate notification to the DOE Grand Junction Projects Office's 24-hour phone line at (970) 248-6070 within 8 hours of issuance of a warning or episode of wamings.

The purpose of this warning is to assist the DOE in monitoring and maintaining the integrity of its Gunnison uranium mill tailings disposal site located about six miles southeast of Gunnison, Colorado, about two miles southwest of the junction of U.S. Highway 50 and County Road 42 (see enclosed map).

If the notification request discussed above is agreeable to you, please sign and return the enclosed reply letter for our records as soon as possible.

Should you have any questions, please contact me at (505) 845-4865.

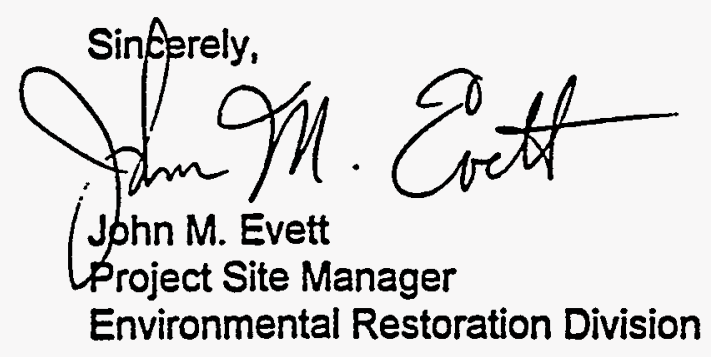

\section{Enclosures}

cc w/o enclosures:

J. Virgona, GJPO 
John M. Evett

Project Site Manager

Environmental Restoration Division

U.S. Department of Energy

P.O. Box 5400

Albuquerque, NM 87115

Dear Mr. Evett:

This letter is to concur with the U.S. Department of Energy (DOE) request for notification as set forth in the DOE's letter. As requested in your letter, this office will contact the DOE's Grand Junction Projects Office at (970) 248-6070 if any unusual event or anomaly is observed or reported at or around the DOE's Gunnison disposal site, Gunnison County, Colorado.

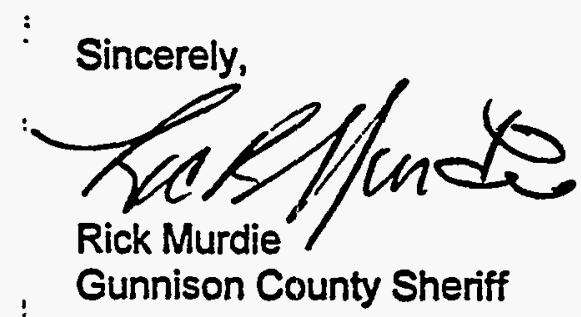

cc: J. Virgona, GJPO

\section{National Earthquake Information Center. World Data Center A for Seismology}

Director

(303) 236-1510

Research

(303) 236-1506
U.S. Geological Survey

Box 25046, DFC, MS-967

Dezper, Colorado 80225 USA

Telex: (WUTCO) 5106014123ESL LD

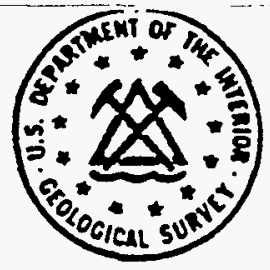

Operations

(303) 236-7500

QED

(800) $358-2663$ 


\section{National Earthquake Information Center}

World Data Center A for Seismology

Director

(303) $236-1510$

Research

(303) 236-1506
C.S. Geological Survey

Box 25046, DFC. MS-96i

Dequer. Colorado 80205 USA

Telex: (WLTCO) 5106014123ESL LD
Operations

(303) 236-1500

QED

(800) 358.2663

Clinton C. Smythe

Engineering and Construction Group Leader

Uranium Mill Tailings Remedial Action

Project Office

2155 Louisiana NE, Suite 4,000

Albuquerque, NM 87110

Dear Mr. Smythe:

This letter is to confirm that the DOE Grand Junction Projects Office (24-hour phone line, (303) 248-6070 has been added to our notification list for the occurrence of earthquakes near the following locations:

\begin{tabular}{|c|c|c|}
\hline Disposal Site & Latitude & Longitude \\
\hline \multicolumn{3}{|l|}{ COLORADO } \\
\hline Durango (Bodo Canyon) & N37.15 & W107.90 \\
\hline Grand Junction & N38.91 & W108.32 \\
\hline Gunnison (Landfill) & $\mathrm{N} 38.51$ & W106.85 \\
\hline Maybell & N40.55 & W107.99 \\
\hline Naturita (Dry Flats) & N38.21 & W108.60 \\
\hline Rifle (Estes Gulch) & N39.60 & W107.82 \\
\hline Slick Rock (Burro Canyon) & N38.05 & W108.87 \\
\hline \multicolumn{3}{|l|}{ IDAHO } \\
\hline Lowman & N44.16 & W115.61 \\
\hline \multicolumn{3}{|l|}{ NEW MEXICO } \\
\hline Ambrosia Lake & N35.41 & W107.80 \\
\hline \multicolumn{3}{|l|}{ NORTHDAKOTA } \\
\hline Bowman & $\mathrm{N} 46.23$ & W103.55 \\
\hline \multicolumn{3}{|l|}{ OREGON } \\
\hline Lakeview (Collins Ranch) & N42.2 & W120.3 \\
\hline \multicolumn{3}{|l|}{ PENNSYLVANIA } \\
\hline Canonsburg & N40.26 & W80.25 \\
\hline Burrell VP & N40.62 & W79.65 \\
\hline \multicolumn{3}{|l|}{ TEXAS } \\
\hline Falls City & N28.91 & W98.13 \\
\hline \multicolumn{3}{|l|}{ UTAH } \\
\hline Mexican Hat & N37.10 & W109.85 \\
\hline Salt Lake City (Clive) & $\mathrm{N} 40.69$ & W113.11 \\
\hline
\end{tabular}




\section{National Earthquake Information Center. \\ World Data Center A for Seismology}

Director

(303) 236-1510

Research (303) 236-1506
U.S. Geological Survey

Box 25046, DFC, MS-967

Deziver, Colorzdo 80225 USA

Telex: (WUTCO) 5106014123ESL UD
Operations

(303) 236-1500

QED

(800) 358-2663

Clinton C. Smythe

$-2-$

We have entered the following selection criteria into our notification program:

1. Any earthquake of magnitude 3.0 or greater, within 0.3 degrees (about 20 miles) of any site shown above, or

2. Any earthquake of magnitude 5.0 or greater, within 1.0 degrees (about 70 miles) of any site shown above.

Sincerely,

Buce 25. Presgeave

Brice Presgrave

U.S. Geological Survey

National Earthquake Information Center

P.O. Box 25046

Mail Stop 967

Denver Federal Center

Denver, Colorado 80225

Piease address future comespondonce to Shert Koyanagi at the above address. I have moved to a different project.

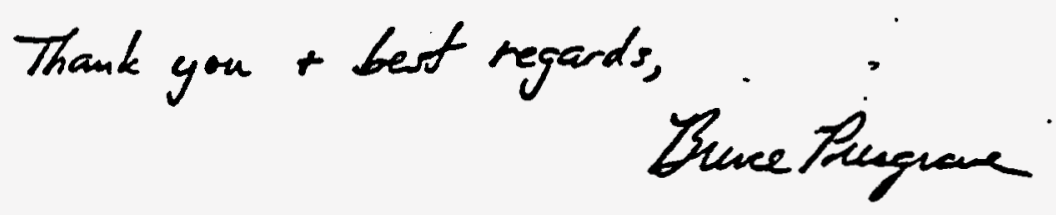



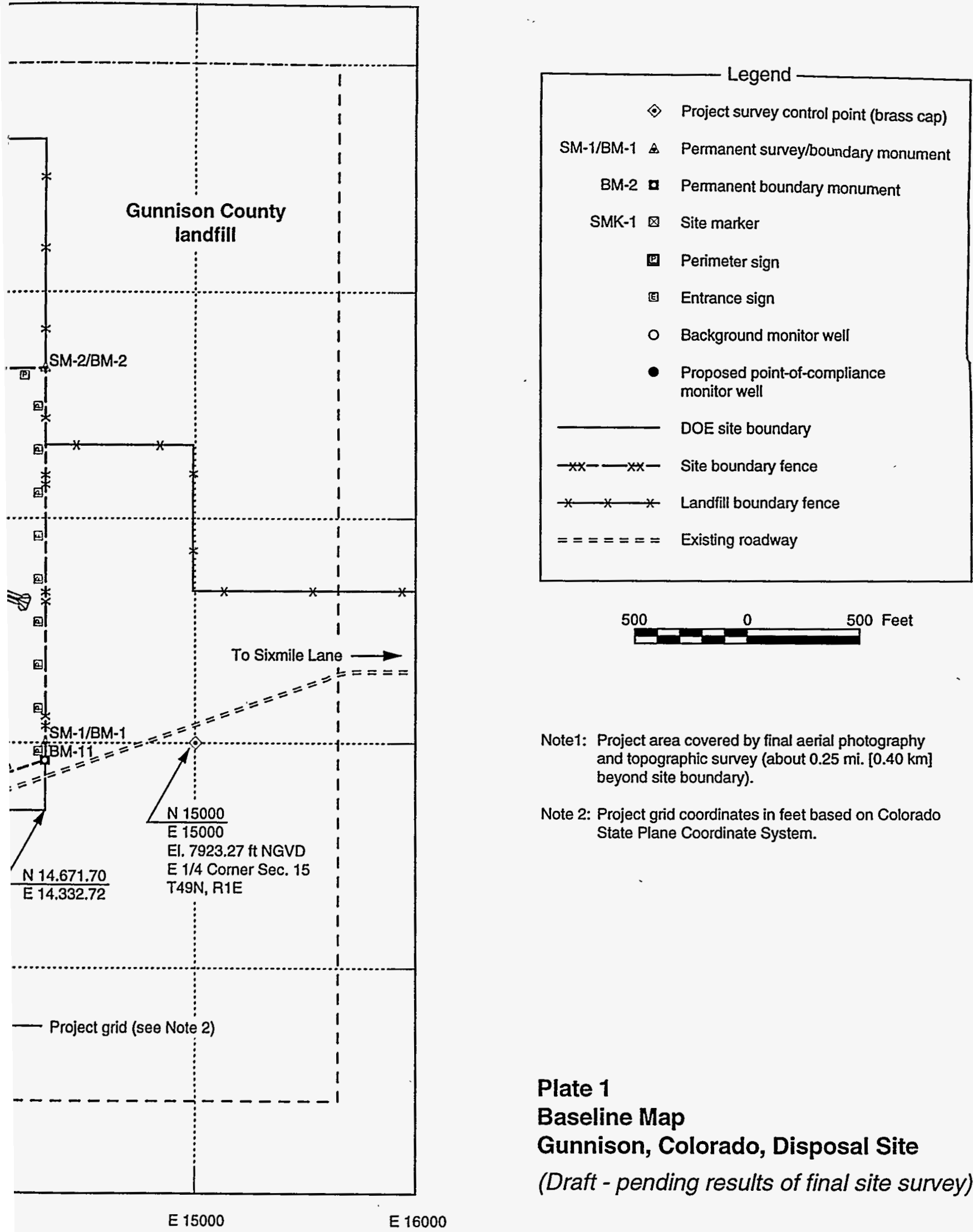

Note1: Project area covered by final aerial photography and topographic survey (about $0.25 \mathrm{mi}$. [0.40 km] beyond site boundary).

Note 2: Project grid coordinates in feet based on Colorado State Plane Coordinate System.

\section{Plate 1}

Baseline Map

Gunnison, Colorado, Disposal Site

(Draft - pending results of final site survey)

Modified from MK-F, 1996. 


\section{LONG-Term SuRveillance PLAN FOR THE GUNNISON, COLORADO DISPOSAL SITE}

May 1996 
This report has been reproduced from the best available copy. Available in paper copy and microfiche

Number of pages in this report: 68

DOE and DOE contractors can obtain copies of this report from:

Office of Scientific and Technical Information

P.O. Box 62

Oak Ridge, TN 37831

(615) 576-8401

This report is publicly available from:

National Technical Information Service

Department of Commerce

5285 Port Royal Road

Springfield, VA 22161

(703) 487-4650 
LONG-TERM SURVEILLANCE PLAN

FOR THE

GUNNISON, COLORADO, DISPOSAL SITE

May 1996

$\vdots$

Prepared for

U.S. Department of Energy

Environmental Restoration Division

UMTRA Project Team

Albuquerque, New Mexico

Prepared by

Jacobs Engineering Group Inc.

Albuquerque, New Mexico 
TABLE OF CONTENTS

\section{Section}

Page

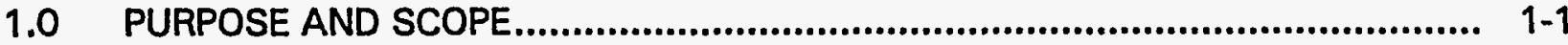

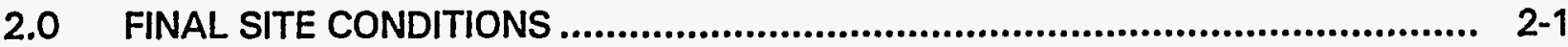

2.1 Site history........................................................................................ 2 2-1

2.2 General description of the site vicinity................................................. 2-2

2.3 Disposal site description ..................................................................... 2-4

2.3.1 Site ownership and legal description ........................................... 2-5

2.3.2 Directions to the disposal site ................................................. 2-5

2.3.3 Description of surface conditions.............................................. 2-5

2.3.4 Permanent site-surveillance features .......................................... 2-6

2.4 Disposal cell design ............................................................................. 2-9

2.5 Ground water characterization............................................................ 2-10

2.5.1 Hydrogeology.................................................................... 2-10

2.5.2 Background ground water quality ................................................ 2-15

2.5.3 Hazardous constituents ............................................................... 2-15

2.6 Ground water protection ................................................................... 2-17

2.6.1 Monitor well network ............................................................ 2-17

2.6.2 Concentration limits for hazardous constituents ............................ 2-20

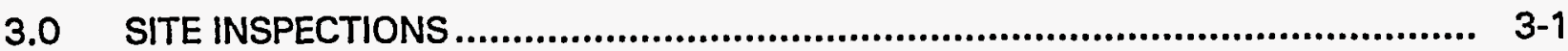

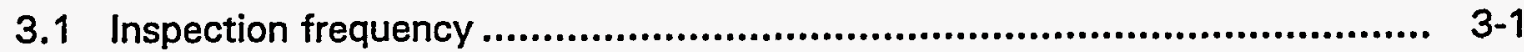

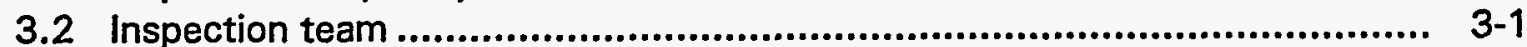

3.3 Site inspection procedures ........................................................... $3-1$

3.4 Follow-up inspections ..................................................................... 3-3

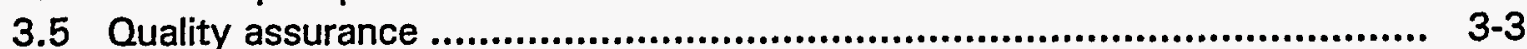

3.6 Site inspection documentation...................................................... $3-3$

3.6.1 Site inspection checklist .................................................... 3-3

3.6.2 Site inspection maps............................................................ $3-4$

3.6.3 Site inspection photographs................................................... $3-4$

3.6.4 Field notes ........................................................................ 3-4

3.6.5 Site inspection report .................................................... $3-5$

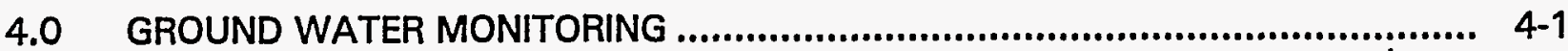

4.1 Ground water monitoring plan ........................................................... 4-1

4.1.1 Direct ground water monitoring network ................................... 4-1

4.1.2 Sampling frequency ............................................................... 4-1

4.1.3 Ground water monitoring team................................................ 4-3

4.1.4 Screening monitoring and exceedance validation.......................... 4-3

4.1.5 Evaluative monitoring .......................................................... 4-4

4.1.6 Indirect monitoring .................................................................. 4-6

4.2 Data validation and quality assurance................................................ 4-6

4.3 Ground water monitoring documentation ............................................ 4-6 


\section{TABLE OF CONTENTS (Concluded)}

Section

Page

5.0 CUSTODIAL MAINTENANCE OR REPAIR 5-1

6.0 CORRECTIVE ACTION 6-1

7.0 EMERGENCY NOTIFICATION AND RESPONSE $7-1$

8.0 RECORD KEEPING AND REPORTING $8-1$

9.0 REFERENCES $9-1$

\section{ATTACHMENT 1 SITE REAL ESTATE INFORMATION} ATTACHMENT 2 AGENCY NOTIFICATION AGREEMENTS 


\section{LIST OF FIGURES}

Figure

2.1 Location map, Gunnison, Colorado, disposal site......................................... 2-2

2.2 Vicinity map, Gunnison, Colorado, disposal site ............................................ 2-3

2.3 DOE monitor well location map, Gunnison, Colorado, disposal site...................... 2-11

2.4 Geologic cross section (north-south) of the disposal cell vicinity, Gunnison, Colorado

2.5 Potentiometric map of the lower Tertiary gravel aquifer, Gunnison, Colorado, disposal site 2-14

2.6 Ground water monitoring network proposed in the Gunnison remedial action plan

\section{LIST OF PLATES}

\section{Plate}

1 Disposal site baseline map, Gunnison, Colorado, site

\section{LIST OF TABLES}

Table

2.1 Locations of permanent surveillance features, Gunnison, Colorado, disposal site

2.2 Monitor well information for wells completed in the Tertiary gravel aquifer, Gunnison, Colorado, disposal site

2.3 Summary of water quality data and proposed concentration limits for hazardous constituents in tailings solutions, Gunnison, Colorado, disposal site...2-21

4.1 Sampling schedule for the monitor well network at the Gunnison, Colorado, disposal site

4.2 Parameters to be measured during screening monitoring at the Gunnison, Colorado, disposal site. 


\section{LIST OF ACRONYMS}

\section{Acronym}

BLM

DOE

EA

EPA

LTSP

$\mathrm{MCL}$

NGVD

NRC

POC

RAP

TDS

UMTRA

UMTRCA

\section{Definition}

Bureau of Land Management

U.S. Department of Energy

environmental assessment

U.S. Environmental Protection Agency

long-term surveillance plan

maximum concentration limit

National Geodetic Vertical Datum

U.S. Nuclear Regulatory Commission

point of compliance :

remedial action plan

total dissolved solids

Uranium Mill Tailings Remedial Action

Uranium Mill Tailings:'Radiation Control Act 


\section{CHANGE HISTORY}

\begin{tabular}{|c|c|c|}
\hline Document version & Date & Pages/comments \\
\hline Rev. 0, Ver. 1 & $2 / 19 / 96$ & Initial version with editorial changes. \\
\hline Rev. 0, Ver. 2 & $4 / 16 / 96$ & $\begin{array}{l}\text { Final version prepared for submittal } \\
\text { to NRC. All DOE review comments } \\
\text { addressed. }\end{array}$ \\
\hline Rev. 0 , Ver. 3 & $5 / 14 / 96$ & More DOE comments addressed. \\
\hline Rev. 1, Ver. 1 & $5 / 23 / 96$ & $\begin{array}{l}\text { DOE review comments incorporated; } \\
\text { minor changes. }\end{array}$ \\
\hline
\end{tabular}




\subsection{PURPOSE AND SCOPE}

This long-term surveillance plan (LTSP) describes the U.S. Department of Energy's (DOE) long-term care program for the Uranium Mill Tailings Remedial Action (UMTRA) Project Gunnison disposal site in Gunnison County, Colorado.

The U.S. Nuclear Regulatory Commission (NRC) has developed regulations for the issuance of a general license for the custody and long-term care of UMTRA Project disposal sites in 10 CFR Part 40. The purpose of this general license is to ensure that the UMTRA Project disposal sites will be cared for in a manner that protects the public health and safety and the environment. For each disposal site to be licensed, the NRC requires the DOE to submit a site-specific LTSP. The DOE prepared this LTSP to meet this requirement for the Gunnison disposal site. The general license becomes effective when the NRC concurs with the DOE's determination of completion of remedial action for the Gunnison site and the NRC formally accepts this LTSP.

This LTSP describes the long-term surveillance program the DOE will implement to ensure that the Gunnison disposal site performs as designed. The program is based on two distinct activities: 1) site inspections to identify threats to disposal cell integrity, and 2) ground water monitoring to demonstrate disposal cell performance. The LTSP is based on the UMTRA Project long-term surveillance program guidance (DOE, 1996) and meets the requirements of 10 CFR $\$ 40.27(\mathrm{~b})$ and 40 CFR $\$ 192.03$. 


\subsection{FINAL SITE CONDITIONS}

Remedial action at the former uranium processing site in Gunnison, Colorado, consisted of excavating and relocating the residual radioactive materials to the Gunnison disposal site. The DOE constructed a disposal cell to control the residual radioactive material in accordance with 40 CFR Part 192. The Gunnison disposal site is fenced, and its perimeter is marked with warning signs. The site completion report (MK-F, 1996) contains a detailed description of the final site conditions.

\section{$2.1 \quad$ SITE HISTORY}

The Gunnison mill, which had a processing capacity of 200 tons (180 metric tons) of ore per day, operated from 1958 to 1962 . The mill ground the ore and then leached it with sulfuric acid and sodium chlorate. After leaching, the uranium-rich solutions and waste solids were separated. The solutions were then treated with sodium carbonate to extract the uranium and the washed solids were dumped in the tailings pile. During its operation, the mill processed about 540,000 tons $(490,000$ metric tons) of uranium ore.

The Uranium Mill Tailings Radiation Control Act (UMTRCA) of 1978 (42 USC $\$ 7901$ et seq.) gave the DOE authority to perform remedial action at the Gunnison processing site. The DOE evaluated the environmental impacts associated with the Gunnison site remedial action in an environmental assessment (EA) (DOE, 1992a). The NRC and the state of Colorado concurred with the DOE's remedial action plan (RAP) (DOE, 1992b) to comply with the requirements of 40 CFR Part 192, Subparts A-C.

The DOE began constructing the disposal cell in 1992. During 1993 and 1994, the DOE relocated uranium mill tailings and other residual radioactive materials (such as contaminated demolition debris, soils, and vicinity property materials) and placed them in the disposal cell. Construction of the disposal cell was completed in 1995 with placement of a radon/infiltration barrier and frost and erosion protection layers.

The DOE has prepared a completion report documenting compliance with the RAP and the site as-built conditions (MK-F, 1996). In addition, the DOE will prepare a final audit report and certification summary and submit it along with the completion report to the NRC for concurrence. Concurrence from the NRC on the completion report will be included the permanent site file.

\subsection{GENERAL DESCRIPTION OF THE SITE VICINITY}

The Gunnison disposal site is in Gunnison County in southwest Colorado on the western slope of the Rocky Mountains (Figure 2.1). The site is approximately 6 miles (mi) (10 kilometers [km]) southeast of the town of Gunnison, Colorado, in Township 49 North, Range 1 East, Section 15, New Mexico Principal Meridian (Figure 2.2). This section provides a brief description of the site vicinity; 


\section{Figure 2.1}

Location Map

Gunnison, Colorado, Disposal Site

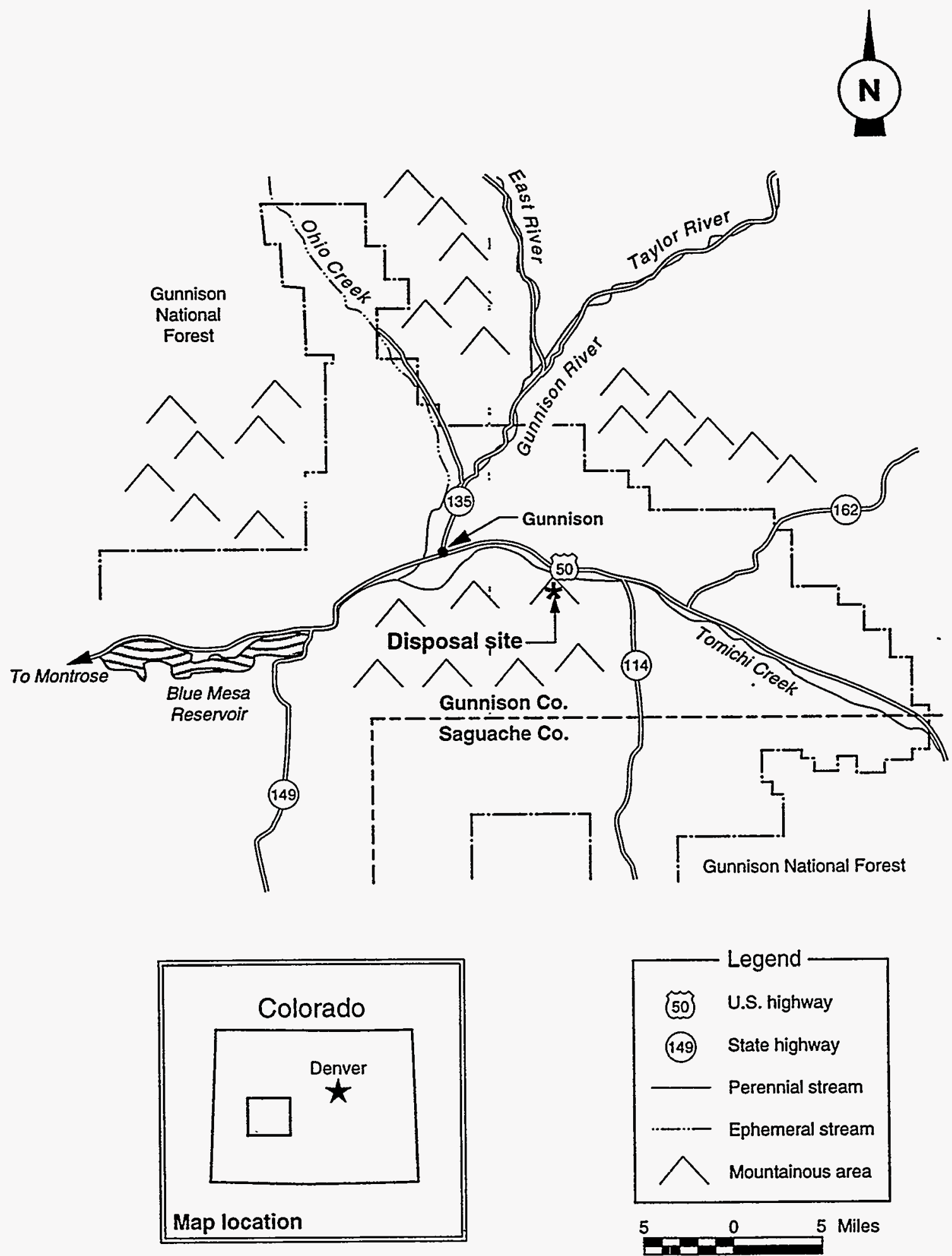


Figure 2.2

\section{Vicinity Map}

\section{Gunnison, Colorado, Disposal Site}
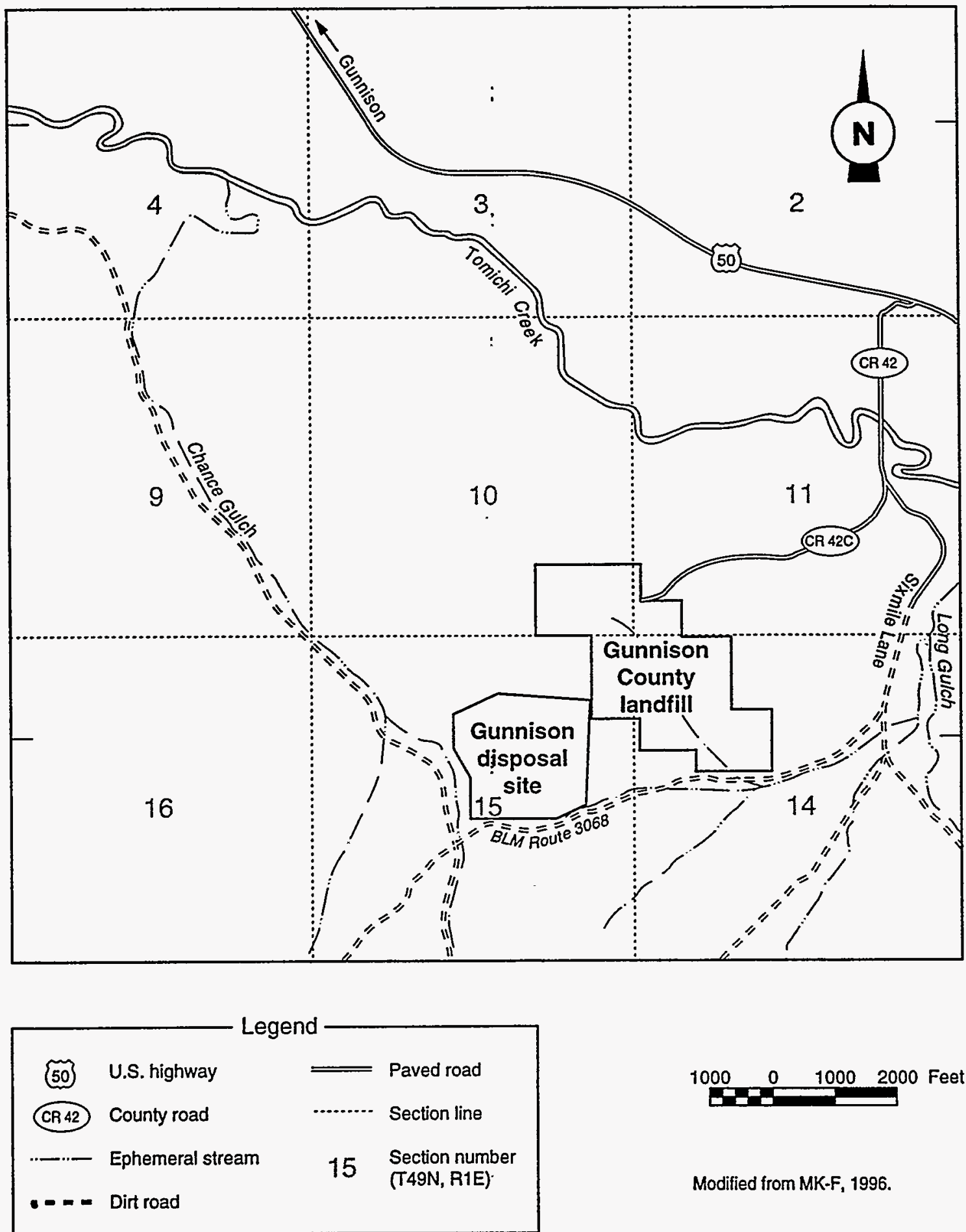

Modified from MK-F, 1996. 
detailed descriptions can be found in the site EA (DOE, 1992a) and the RAP (DOE, 1992b).

The general climatic regime in the vicinity of the Gunnison disposal site is semiarid. The area is characterized by low humidity, frequent sunny days, and large diurnal and seasonal temperature ranges. The average annual precipitation is 11 inches ( 280 millimeters [mm]). The highest monthly rainfall usually occurs during July and August, while the least rainfall occurs from April through June. The adjusted annual evapotranspiration for the area is approximately 10 inches $(250 \mathrm{~mm})$. Winds are highly variable and heavily influenced by the local mountain and valley topography.

The average elevation of the Gunnison disposal site is about 8040 feet $(\mathrm{ft})$ (2450 meters [m]) above National Geodetic Vertical Datum (NGVD) of 1929. The site is on the southern slope of an 8402- $\mathrm{ft}(2561-\mathrm{m})$-high mountain, and is bounded on the west by Chance Gulch and on the east by Long Gulch. The disposal site lies on a drainage divide on a very gently sloping, dissected surface. Soil formation and movement of the material within the surficial deposits are affected by seasonal freeze-thaw cycles. Sheet flow erosion appears to be the dominant process currently shaping the local topography. However, net surface erosion in the disposal site area appears to be insignificant. Some local soil erosion occurs off the site in the small rills and gullies at the heads of the large drainage channels that dissect the area.

Runoff from snowmelt and rainstorms contributes only small amounts of overland surface water flow toward the disposal site. A large gully extends along the northern boundary of the site and drains into Chance Gulch. A small gully is located on the southeastern portion of the site. Runoff in this gully flows into the drainage divide south of the disposal site, eventually draining into Long Gulch. Flooding is not considered a hazard at the site because of the distance from and elevation above Tomichi Creek, the closest perennial stream.

Most of the land in the area is primarily used for seasonal livestock grazing and wildlife habitat and, to a lesser extent, mineral extraction and recreation. There is no potential for future natural resource development in the immediate site vicinity. Additional local land use includes operation of the Gunnison County landfill, which is northeast of the disposal site. The closest residence is about $1.5 \mathrm{mi}(2.4 \mathrm{~km})$ east of the site and the nearest downgradient registered well is located $7500 \mathrm{ft}(2300 \mathrm{~m})$ from the site.

\subsection{DISPOSAL SITE DESCRIPTION}

This section provides a brief description of the disposal site; detailed descriptions can be found in the site RAP (DOE, 1992b) and completion report (MK-F, 1996). 


\subsubsection{Site ownership and legal description}

The government currently owns the Gunnison disposal site and most of the surrounding area. The Bureau of Land Management (BLM) permanently transferred administration of public land to the DOE in 1992 for use as the Gunnison disposal site. The BLM administers the adjacent surrounding lands, except for the Gunnison County landfill. Attachment 1 provides a legal description of the disposal site. Plate 1 shows the final site boundary and identifies ownership of the site and surrounding areas at the time of licensing.

\subsubsection{Directions to the disposal site}

The Gunnison disposal site can be reached by automobile via paved and graded dirt roads (Figure 2.2 ) by following these directions.

1. From Gunnison, Colorado, take U.S. Highway 50 east about $5 \mathrm{mi}(8 \mathrm{~km})$ from the junction of State Highway 135 to County Road 42.

2. Turn right (south) onto County Road 42 (also known as Sixmile Lane) and travel just over $1 \mathrm{mi}(1.6 \mathrm{~km})$ to BLM Route 3068. (Sixmile Lane turns into a dirt road past the turnoff for the Gunnison County landfill.)

3. Turn right onto BLM Route 3068 and travel west for about $1 \mathrm{mi}(1.6 \mathrm{~km}$ ).

4. Follow BLM Route 3068 until you come to the turnoff on the right (north) for the access gate to the site. The site access point also is marked by a site entrance sign and granite site marker located just inside the site fence.

Entry to the disposal site is restricted by a barbed-wire fence around the site perimeter. The south access gate is kept locked and the key needed to enter the site may be obtained from the DOE.

\subsubsection{Description of surface conditions}

The Gunnison disposal site is located on approximately 92 acres (ac)

(37 hectares [ha]) of land (Plate 1). The completion report (MK-F, 1996) contains a detailed description of the final site conditions including the results of the final site topographic survey. The site is enclosed with a 5-strand, barbedwire fence, and the perimeter also is marked with warning signs, boundary markers, and survey monuments (Section 2.3.4). The tailings and other contaminated materials are contained in a rock-covered disposal cell located in the center of the site.

The final site grading has all areas contoured to promote drainage away from the disposal cell. The DOE used a mix of five species of grasses to revegetate all disturbed areas of the disposal site not covered by riprap (MK-ECE, 1995). 
"At the completion of remedial action, the DOE documented final disposal site conditions with site maps, as-built drawings, and ground and aerial photographs (MK-F, 1996). This information illustrates baseline conditions for comparison to future disposal site conditions. Lithologic logs and construction data for monitor wells drilled on and around the disposal site provide detailed information on site hydrogeology. All original drawings, site maps, well logs, and photographs are part of the Gunnison permanent site file.

\subsubsection{Permanent site-surveillance features}

Survey and boundary monuments, site markers, and warning signs are the permanent long-term surveillance features of the Gunnison disposal site. In addition, the disposal site also has point-of-compliance (POC) and background ground water monitor wells. Plate 1 shows the locations of these features and Table 2.1 provides their survey grid coordinates. Typical construction and installation specifications for these features are shown in the long-term surveillance guidance (DOE, 1996) and subcontract documents (MK-ECE, 1995).

Three survey monuments establish permanent horizontal control based on the Colorado State Plane Coordinate System (Central Zone) and are referenced to the Project Survey Control Point, which is located about $700 \mathrm{ft}(210 \mathrm{~m})$ east of the southeast corner of the site at an elevation of $7923.32 \mathrm{ft}(2415.03 \mathrm{~m})$ above NGVD. The three permanent survey monuments (SM-1, SM-2, and SM-3) are Berntsen RT- 1 markers set in concrete, with the monument about 4 inches $(10 \mathrm{~cm})$ above ground level. Magnets in the markers permit easier detection if they become buried over time. The survey monument identification number is stamped on the top of the metal cap.

Eleven boundary monuments lie along the final site boundary. The three RT-1 survey monuments serve a dual purpose as boundary monuments (SM-1 as $\mathrm{BM}-1, \mathrm{SM}-2$ as $\mathrm{BM}-2$, and $\mathrm{SM}-3$ as $\mathrm{BM}-3)$. The remaining eight boundary monuments (BM-4 to BM-11) are Berntsen Model A-1 survey monuments set in concrete, with the monument about 1 inch $(25 \mathrm{~mm})$ above ground level. Magnets in the A-1 monuments allow easier detection if they become buried. The boundary monument identification number is stamped on the top of the metal cap.

Two unpolished granite markers with an incised message identify the Gunnison disposal site. The message includes a drawing showing the general location of the stabilized disposal cell within the site boundaries, the date of closure (26 July 1995), the weight of tailings $(1,140,000$ dry tons $[1,034,000$ metric tons]), and the amount of radioactivity (175 curies of radium-226). Site marker SMK-1 near the south access gate to the site is set in reinforced concrete that extends $3 \mathrm{ft}(0.9 \mathrm{~m})$ below the ground surface. Site marker SMK-2 at the crest of the disposal cell is set in reinforced concrete that extends to the top of the frost protection barrier. 
Table 2.1 Locations of permanent surveillance features,

Gunnison, Colorado, disposal site

\begin{tabular}{cc}
\hline Feature & Location coordinates $^{\mathrm{a}}$ \\
\hline Site markers & N 14,678; E 12,600 \\
SMK-1 & N 15,539; E 12,974
\end{tabular}

Survey/boundary monuments

$\begin{array}{ll}\text { SM-1/BM-1 } & \text { N 15,002; E 14,326 } \\ \text { SM-2/BM-2 } & \text { N 16,648; E 14,321 } \\ \text { SM-3/BM-3 } & \text { N 16,663; E 12,500 }\end{array}$

Boundary monuments

BM-4

N 16,394; E 11,660

BM-5

N 15,828; E 11,662

BM-6

N 15,343; E 11,996

BM-7

N 15,009; E 11,998

BM-8

N 14,685; E 11,999

BM-9

N 14,684; E 12,326

BM-10

N 14,679; E 13,632

$\mathrm{BM}-11$

N 14,897; E 14,327

\section{Background well}

GUN-08-0716

N 17499; E 13,216

GUN-08-0609

N14,961; E 12,563

\section{POC wells}

GUN-08-0720

N 15,500; E 12,370

GUN-08-0721

N 16,120; E 12,620

GUN-08-0722

N 16,080; E 13,440

GUN-08-0723

N 15,750; E 13,670

GUN-08-0724

N 15,500; E 13,500

GUN-08-0725

N 15,000; E 13,370 
The DOE has posted property use warning signs (18 inches $[460 \mathrm{~mm}$ ] by 24 inches $[610 \mathrm{~mm}]$ ) around the disposal site perimeter at approximately $200-\mathrm{ft}$ $(60-\mathrm{m})$ intervals. These warning signs (41 total) are attached to the perimeter fences. The site entrance sign is at the south access gate to the disposal site near site marker SMK-1. The entrance sign also displays the DOE 24-hour phone number to call concerning the site.

The Gunnison disposal site will have six POC monitor wells, two background wells, and eight ground water-level monitor wells (see Section 2.6.1) in the uppermost aquifer. The DOE installs and develops ground water monitor wells in accordance with U.S. Environmental Protection Agency (EPA) guidance (EPA, 1986). The lithologic logs for background wells (GUN-08-0716 and GUN-080609) and ground water level-monitoring wells (Table 2.1) are in the site file. Logs for the POC wells will be added to the site file after the wells have been installed.

\section{$2.4 \quad$ DISPOSAL CELL DESIGN}

The 29-ac (12-ha) disposal cell is located on an alluvial slope upland from any active stream channels. The area of the disposal cell is not subject to any significant hazard from slope failure processes such as landslides, debris flows, mud flows, and rock falls. The geomorphic processes posing a potential hazard to the stabilized disposal cell are ephemeral drainage channel changes, lowgradient slope erosion, and wind erosion; however, these processes are not reasonably expected to affect the disposal cell within the next 1000 years, or in any case for at least 200 years.

The disposal cell is constructed partially below grade and rises above the surrounding terrain to a maximum élevation of about $8065 \mathrm{ft}(2458 \mathrm{~m})$ above NGVD. The disposal cell contains approximately 740,000 cubic yards $\left(565,000\right.$ cubic meters $\left.\left[\mathrm{m}^{3}\right]\right)$ of relocated tailings and other residual radioactive materials, primarily contaminated soil and demolition debris. The disposal cell is capped with a 9-ft (3-m)-thick multiple-component cover.

An 1.5-ft $(0.45-\mathrm{m})$-thick radon/infiltration barrier is placed over the contaminated materials. This barrier is constructed of clayey soil amended with bentonite and is designed to reduce the radon-222 flux from the disposal cell to less than 20 picocuries per square meter per second and minimize water infiltration into the tailings. A 6-ft (2-m)-thick layer of compacted soil lies on top of the radon/infiltration barrier to prevent the clayey barrier from being adversely affected by freezing and thawing cycles. A 0.5-ft $(0.15-\mathrm{m})$-thick, coarse-grained bedding layer is between the radon/infiltration barrier and the frost protection barrier to provide a capillary break and promote drainage of infiltrating water away from the radon barrier. The topslopes and sideslopes of the disposal cell are capped with rock to protect against wind and water erosion and prevent damage to the underlying radon/infiltration barrier. A rock-lined diversion ditch abuts the upslope portion of the disposal cell to divert surface flow away from the cell. 
The erosion protection layer is $0.5-\mathrm{ft}(0.15-\mathrm{m})$-thick riprap on the topslopes and 1-ft $(0.3-\mathrm{m})$-thick riprap on the sideslopes. A $0.5-\mathrm{ft}(0.15-\mathrm{m})$-thick bedding layer is between the riprap and the radon/infiltration barrier to prevent damage to the barrier by rocks and loss of the fined-grained radon/infiltration barrier material. The maximum grade is $\mathbf{2 . 5}$ percent on the topslopes and 33 percent on the sideslopes. These grades, in conjunction with the bedding layer, will allow excess surface water to run off the disposal cell and be conveyed to adjacent site grades in a manner that minimizes the risk of significant erosion. The components of both the topslope and sideslope covers are intended to minimize the potential for deep percolation of precipitation into the residual radioactive material.

At the toe of the disposal cell there is a riprap apron, varying in thickness from $1.5 \mathrm{ft}(0.45 \mathrm{~m})$ to $4 \mathrm{ft}(1.2 \mathrm{~m})$. At the ground surface, riprap protection extends up to $20 \mathrm{ft}(6 \mathrm{~m})$ from the toe of the disposal cell. The 1800-ft $(550-\mathrm{m})$-long diversion ditch is also lined with riprap.

Detailed engineering drawings of the disposal cell are in the site completion report (MK-F, 1996).

\section{GROUND WATER CHARACTERIZATION}

This section briefly describes the hydrogeologic units and background ground water quality at the Gunnison disposal site and identifies the constituents of concern at the site. More detail on ground water characterization of the site is found in the Gunnison RAP (DOE, 1992b).

\subsubsection{Hydrogeology}

The hydrogeology of the Gunnison disposal site was characterized during preparation of the RAP (DOE, 1992b). The locations of monitor wells installed during the characterization efforts are presented in Figure 2.3. Four regional Tertiary hydrogeologic units underlie a thin veneer of recent alluvium at the disposal site. In descending order these units are 1) upper Tertiary gravels that form an unsaturated zone, 2) lahar breccia and undifferentiated volcaniclastic mudflows that comprise a low permeability semiconfining zone, 3) lower Tertiary gravels that comprise the uppermost (regional) aquifer, and 4) undifferentiated Tertiary gravels to the north where the intervening volcaniclastic mudflow pinches out. A geologic cross section is provided in Figure 2.4. Both the upper and lower Tertiary gravels consist of silty and clayey sand, subrounded cobbles, and welded tuff. The lahar breccia and volcaniclastic mudflows mentioned above generally form a semiconfining zone that prohibits or retards the movement of ground water downward to the lower Tertiary gravels (uppermost aquifer). In the northern portion of the project site, where the lahar breccia is absent, the upper and lower Tertiary gravels are essentially one hydrogeologic unit. 
Figure 2.3

DOE Monitor Well Location Map

Gunnison, Colorado, Disposal Site

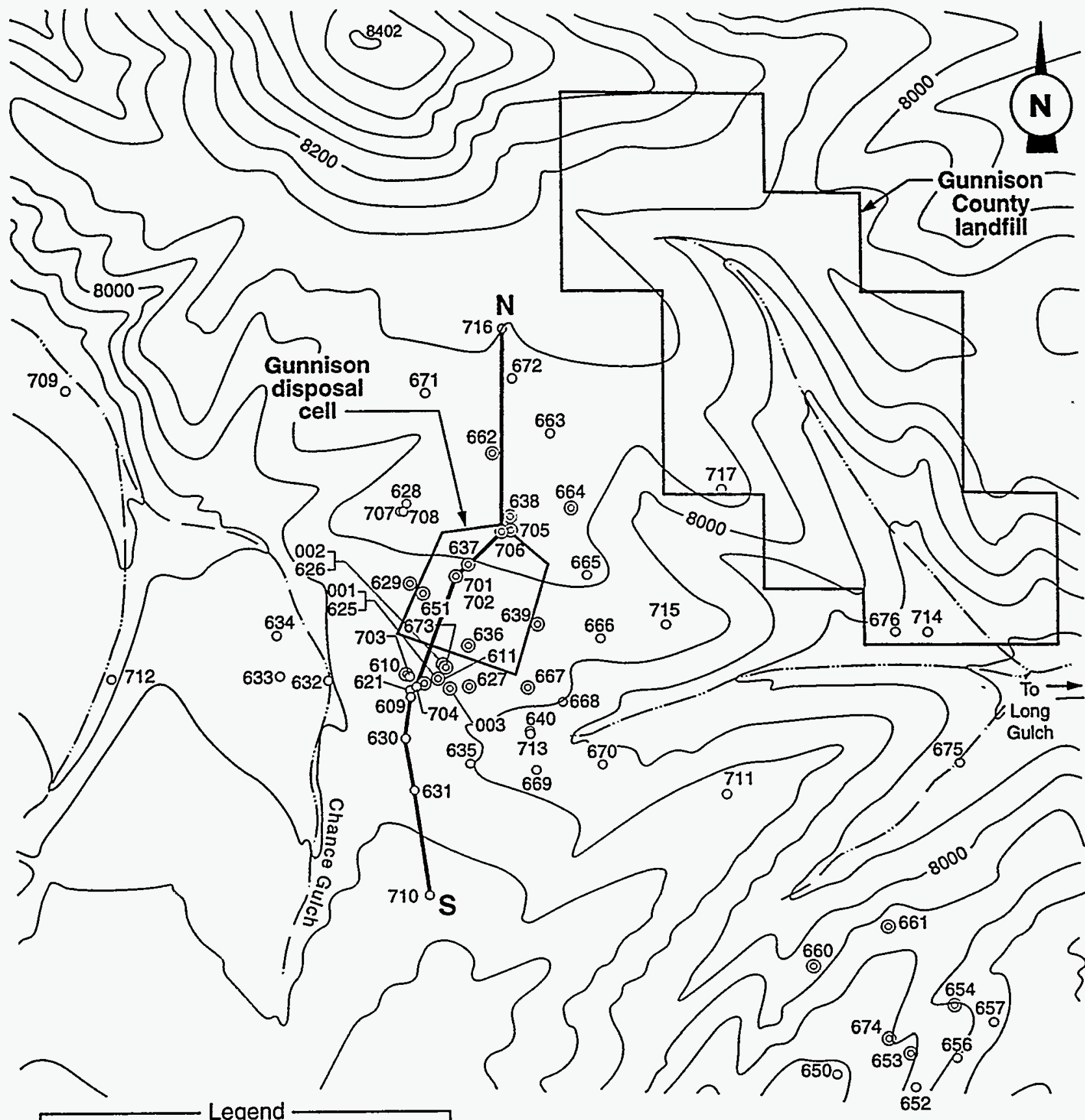

Legend

Note: Contour intervals $=40 \mathrm{ft}$.

- 716 Existing DOE monitor well

(-) 667 Abandoned DOE monitor well

-..... Ephemeral stream

$\mathrm{N}-\mathrm{S}$ Cross section line

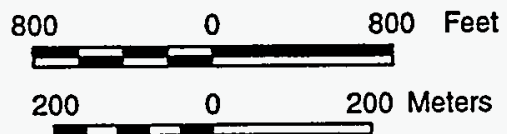

MAC; SITE/GIN/LTSP/MONWELLOC 
Figure 2.4

Geologic Cross Section (North-South) of the Disposal Cell Vicinity Gunnison, Colorado

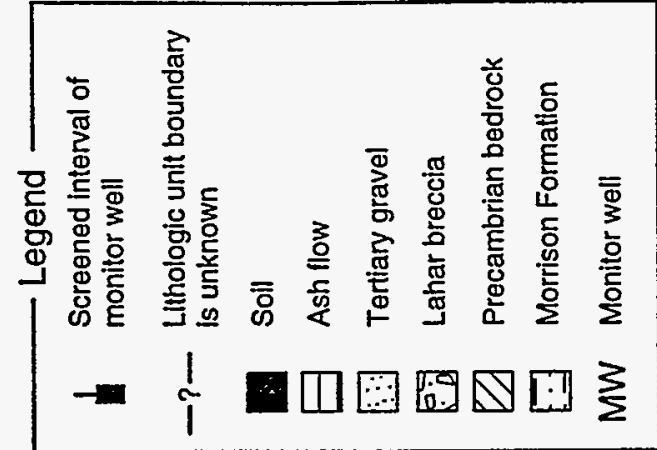

$\boldsymbol{\infty}$

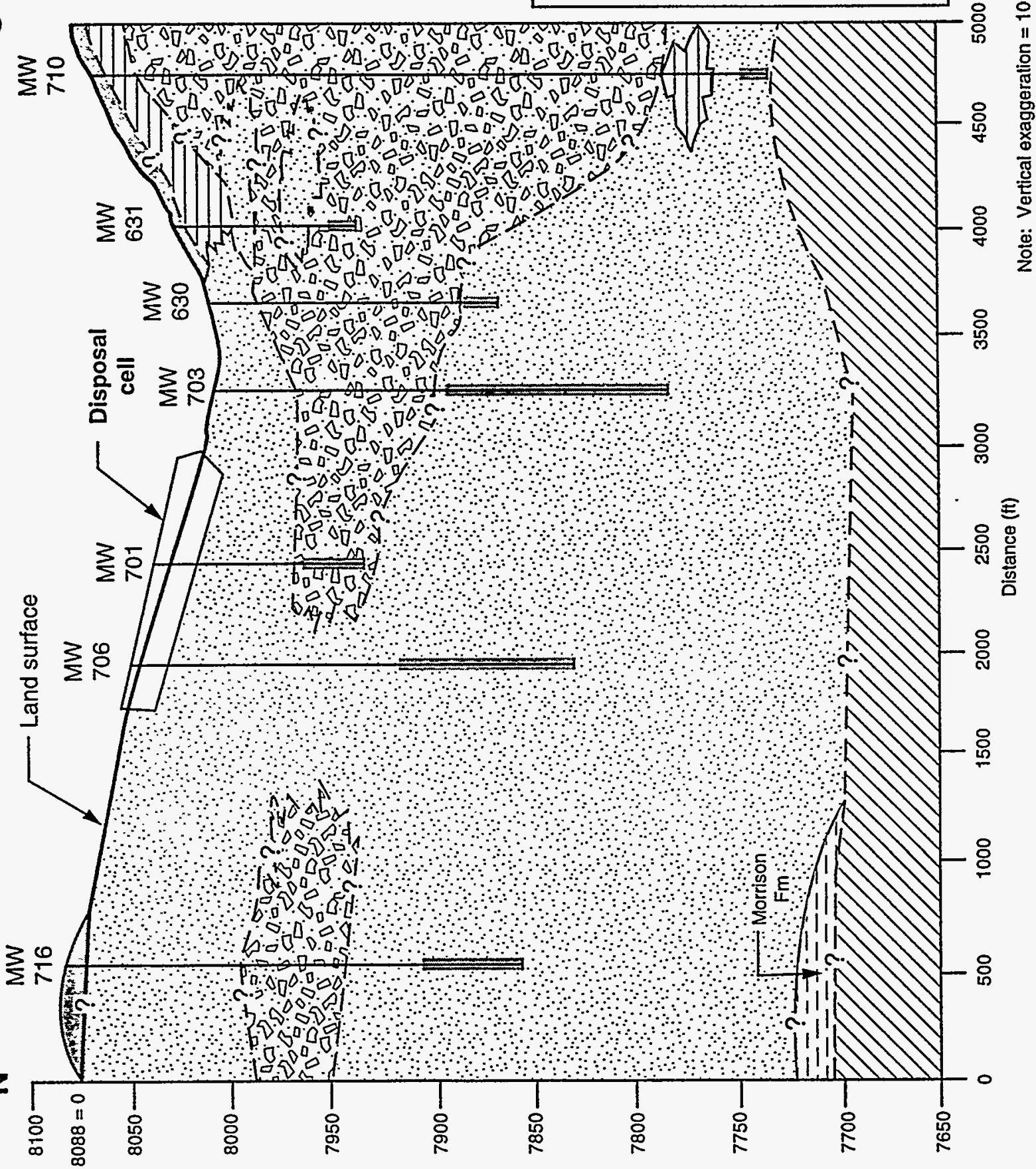

(1) әэejuns puel Mojaq uldəo

MAC: SITFIGUN/RTSP'GEOX-SEC (N-S) 
The Jurassic Morrison Formation, Jurassic Junction Creek Sandstone, and Precambrian metasedimentary and gneissic crystalline rock underlie the Tertiary gravels. The depth to these units averages $300 \mathrm{ft}(90 \mathrm{~m})$ below the surface.

At the Gunnison disposal site, the uppermost aquifer occurs in the lower portion of a regional Tertiary gravel unit; the top of the aquifer is, on average, $110 \mathrm{ft}$ $(34 \mathrm{~m})$ below the disposal cell. Material thickness of the uppermost aquifer ranges from 43 to $240 \mathrm{ft}(13$ to $73 \mathrm{~m})$ and averages $170 \mathrm{ft}(52 \mathrm{~m})$. A semiconfining zone composed primarily of the lahar breccia and volcaniclastic mudflow strata extends from the south and intertongues with the Tertiary gravels beneath the site. The semiconfining zone is present beneath the disposal cell but absent in the northern portion of the site area. Because wells completed within the volcaniclastic strata are incapable of yielding 150 gallons $\left(0.57 \mathrm{~m}^{3}\right)$ per day per year, these strata are not considered to be an aquifer at the disposal site (DOE, 1992b).

Figure 2.5 is a potentiometric map of the lower Tertiary gravel aquifer. Because the disposal site is located within a topographic saddle, ground water flow at the disposal site is complex. In the immediate vicinity of the UMTRA Project disposal site, the primary component of flow is east, following the general topographic trend toward Long Gulch. However, as shown in Figure 2.5, a ground water divide is present in the disposal cell area causing a component of ground water beneath the site to flow to the west. The quality of the ground water under the Gunnison County landfill is not expected to affect the disposal site, as discussed in the RAP (DOE, 1992b).

Aquifer testing shows the uppermost aquifer responds as a confined aquifer when the lahar breccia and volcaniclastic deposits are present. Because the hydraulic conductivity of the lahar breccia and volcaniclastic deposits is very low $10.007 \mathrm{ft}$ per day $\left[2.5 \times 10^{-7} \mathrm{~cm}\right.$ per second] or less) (DOE, 1992b), they act as an aquitard to the downward movement of water. The hydraulic conductivity of the Tertiary gravel aquifer ranges from 0.4 to $0.5 \mathrm{ft}$ per day 10.0001 to $0.0002 \mathrm{~cm}$ per second). No lateral boundaries were observed during two aquifer pumping tests (24 and 72 hours in duration) in the lower Tertiary gravel aquifer, and none of the monitor wells completed in the lahar deposits responded to pumping in the lower Tertiary gravel aquifer. In the lower Tertiary gravel aquifer, the primary (easterly) horizontal hydraulic gradient ranges from 0.004 to 0.014 , and averages 0.010 (DOE, 1992b). Linear velocities of the uppermost aquifer were calculated by applying Darcy's Law using the calculated range of hydraulic conductivities, 0.4 to $0.5 \mathrm{ft}$ per day $(0.0001$ to $0.0002 \mathrm{~cm}$ per second); hydraulic gradients, 0.004 to $0.014 ;$ and an assumed porosity value of 0.25 for gravelly material appropriate for the site (Freeze and Cherry, 1979; Davis and DeWiest, 1966). From this calculation, the average linear ground water velocities in the uppermost aquifer (Tertiary gravels) are estimated to range from 2 to $10 \mathrm{ft}$ per year $\left(2 \times 10^{-6}\right.$ to $10 \times 10^{-6} \mathrm{~cm}$ per second), averaging approximately $7 \mathrm{ft}$ per year $\left(7 \times 10^{-6} \mathrm{~cm}\right.$ per second) (DOE, 1992b). 


\section{Figure 2.5}

\section{Potentiometric Map of the Lower Tertiary Gravel Aquifer}

Gunnison, Colorado, Disposal Site

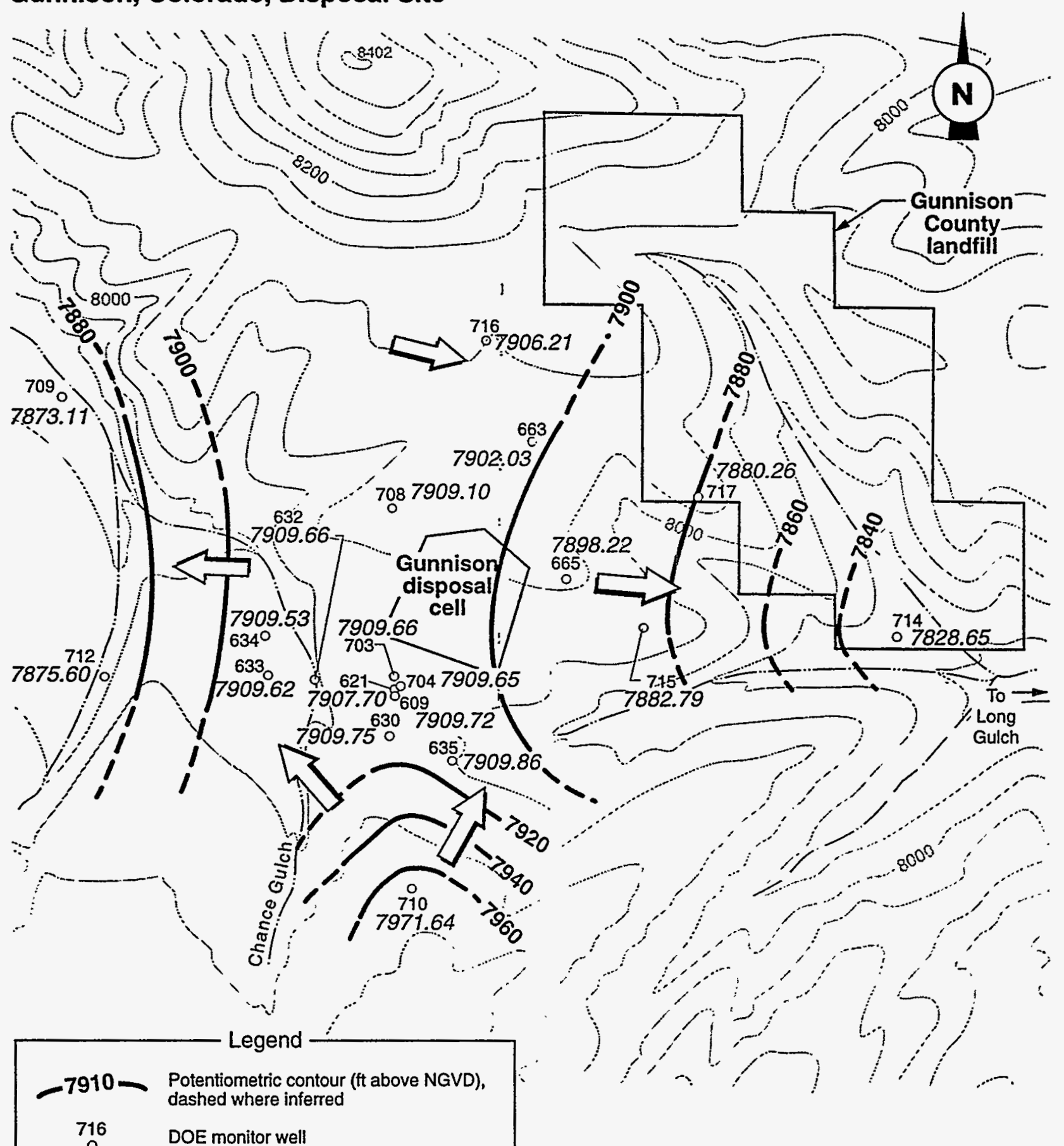

7906.21 Ground water elevation (ft above NGVD), data collected October 1995

Note: Contour intervals $=40 \mathrm{ft}$.

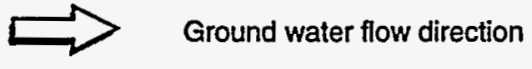

$0 \quad 800$ Feet

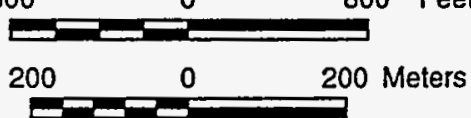

MAC: SITEIGUNLTSPPPOTENLOWRTERT 


\subsubsection{Background ground water quality}

Periodic water quality sampling has been conducted at the Gunnison disposal site since 1988. Background water quality has been determined for the Tertiary gravel aquifer and the overlying semiconfining lahar breccia and volcaniclastic unit. A discussion of the water quality in the semiconfining lahar volcaniclastic unit is provided in the RAP (DOE, 1992b). As discussed in the RAP, monitoring within the semiconfining unit is not required; therefore, background water quality for this unit is not presented in this LTSP.

Table 2.2 provides construction information for 16 monitor wells sampled to determine background ground water quality in the Tertiary gravel aquifer. Background water quality was determined using wells that were sampled only before the start of disposal cell construction (June 1992) and wells located upgradient of the site that have been sampled since the start of cell construction. Water quality data collected from these wells cannot be affected by potential releases from the disposal cell.

Water quality data for the disposal cell site indicate that there are small but distinct differences in background water quality in the uppermost aquifer (the lower Tertiary gravel aquifer). Ground water south and southeast of the cell has slightly greater concentrations of total dissolved solids (TDS) and major elements when compared to ground water to the north and northeast of the cell. For example, sulfate concentrations average $65 \mathrm{mg} / \mathrm{L}$ south of the cell, and $14 \mathrm{mg} / \mathrm{L}$ north of the cell. The disposal cell is at the boundary between these two types of background ground water and thus ground water at the POC likely includes both the higher and lower TDS types. In general, there are little or no differences in background trace element concentrations (e.g., uranium and arsenic) between the two types of ground water.

The $\mathrm{pH}$ values in background ground water quality in the uppermost aquifer range from 6.9 to 9.9 . TDS concentrations range from 206 to 417 milligrams per liter $(\mathrm{mg} / \mathrm{L})$. Analyses of background ground water samples indicate that concentrations of arsenic, net gross alpha, and radium-226 and -228 slightly exceeded the EPA UMTRA Project maximum concentration limits (MCL) (Table 1 of 40 CFR Part 192 Subpart A) in the Tertiary gravels in one or more DOE monitor wells (GUN-08-0609, -0610, -0626, -0630, -0632, -0639, -0663, -0704 , and -0715$)$. Because the occurrences of these concentrations in excess of the EPA MCLs were noted prior to tailings placement in the disposal cell, the exceedances are believed to be caused by naturally occurring sources in the aquifer materials that are leaching into the ground water system.

\subsubsection{Hazardous constituents}

Ground water samples initially were evaluated for hazardous constituents generally expected to be in or derived from the residual radioactive materials related to the uranium processing activities. The list of constituents was 
Table 2.2 Monitor well information for wells completed in the Tertiary gravel aquifer, Gunnison, Colorado, disposal site

\begin{tabular}{|c|c|c|c|c|c|c|}
\hline \multirow[b]{3}{*}{ Well } & & & \multicolumn{4}{|c|}{$\begin{array}{c}\text { Screened interval } \\
\text { (depth below surface) }\end{array}$} \\
\hline & \multicolumn{2}{|c|}{ Well diameter } & \multicolumn{2}{|c|}{ (ft) } & \multicolumn{2}{|c|}{ (m) } \\
\hline & (inches) & $(\mathrm{cm})$ & top & bottom & top & bottom \\
\hline $609^{a}$ & 2 & 5 & 138 & 148 & 42 & 45 \\
\hline $610^{a, b}$ & 2 & 5 & 137 & 147 & 42 & 45 \\
\hline $626^{a, b}$ & 2 & 5 & 130 & 140 & 40 & 43 \\
\hline $630^{\mathrm{a}}$ & 4 & 10 & 127 & 137 & 39 & 42 \\
\hline $632^{a}$ & 4 & 10 & 105 & 115 & 32 & 35 \\
\hline $634^{a}$ & 4 & 10 & 95 & 105 & 29 & 32 \\
\hline $635^{a}$ & 4 & 10 & 151 & 161 & 46 & 49 \\
\hline $637^{a, b}$ & 4 & 10 & 157 & 167 & 48 & 51 \\
\hline $638^{a, b}$ & 4 & 10 & 166 & 176 & 51 & 54 \\
\hline $639^{a, b}$ & 4 & 10 & 147 & 157 & 45 & 48 \\
\hline $663^{a}$ & 2 & 5 & 171 & 173 & 52 & 53 \\
\hline $703^{a}$ & 4 & 10 & 229 & 349 & 70 & 106 \\
\hline $704^{a}$ & 6 & 15 & 107 & 227 & 33 & 69 \\
\hline $708^{a}$ & 4 & 10 & 155 & 165 & 47 & 50 \\
\hline 713 & 4 & 10 & 205 & 215 & 62 & 66 \\
\hline 714 & 4 & 10 & 134 & 144. & 41 & 44 \\
\hline 715 & 4 & 10 & 132 & 172 & 40 & 52 \\
\hline $716^{a}$ & 4 & 10 & 185 & 225 & 56 & 69 \\
\hline $717^{\mathrm{a}}$ & 4 & 10 & 160 & 200 & 49 & 61 \\
\hline
\end{tabular}

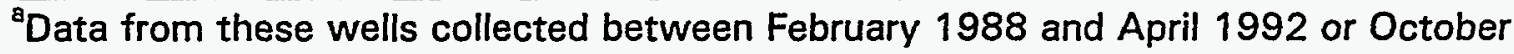
1995 were used to establish background water quality.

${ }^{b}$ Well decommissioned after April 1992.

modified during subsequent sampling events to reflect hazardous constituents related to uranium processing activities at the Gunnison processing site (DOE, 1994). After evaluating existing ground water quality data, the DOE chose the following constituents by comparing potentially hazardous constituents detected in the tailings source term and their relative concentrations in background ground water: 
- antimony

- arsenic

- beryllium

- cadmium

- chromium

- cobalt

- copper
- net gross alpha

- lead

- molybdenum

- nickel

- nitrate

- radium-226 and -228

- selenium

\subsection{GROUND WATER PROTECTION}

The ability of the disposal cell to protect ground water depends on its engineering features. The design of the disposal cell minimizes contaminant migration from the disposal cell into foundation materials. The disposal cell will meet established ground water concentration limits at the POC wells in the uppermost aquifer because:

1. The multicomponent disposal cell cover will limit infiltration of precipitation into the cell, thereby minimizing long-term leaching of hazardous components from the tailings.

2. The contaminated materials were placed at a moisture content that produces almost no transient drainage. The placement moisture content of the tailings is approximately equal to the in situ moisture content. The use of water for construction and dust suppression was controlled. As a result, very little seepage will be transmitted through the unsaturated zone during the design life of the disposal cell.

3. Depth to the uppermost aquifer averages over $100 \mathrm{ft}(30 \mathrm{~m})$; the aquifer is confined by a dense, clayey unit beneath the disposal cell.

4. Geochemical characteristics of the foundation soils and rock are favorable for attenuating hazardous constituents in tailings seepage from the base of the disposal cell. Hazardous constituents that exceed the MCLs or statistical maximum background concentrations are precipitated or adsorbed in the unsaturated zone before they reach the water table in the uppermost aquifer.

\subsubsection{Monitor well network}

The Gunnison RAP (DOE, 1992b) recommended monitoring at six POC monitor wells, existing background DOE monitor wells upgradient of the disposal cell, and existing DOE monitor wells downgradient from the proposed POC wells (including wells 663 and 716). Currently, water samples are collected from eight monitor wells at the disposal site. The sampled wells are GUN-08-0663, $-0707,-0708$, and -0713 through -0717 . The sampling of these wells, as proposed in the RAP, will be altered under the LTSP (Table 2.1). The monitor well network proposed under the LTSP is shown in Figure 2.6. Justification for the modifications to the ground water monitoring network is provided below. 
The monitor well network for long-term surveillance monitoring will included six POC wells and two background monitor wells. The six POC wells will be installed approximately $50 \mathrm{ft}(15 \mathrm{~m})$ from the disposal cell around the east, west, and north perimeter (Figure 2.6 and Plate 1). These wells will be installed and developed in accordance with standard operating procedures that are consistent with the EPA guidance (EPA, 1986) to ensure that representative ground water samples are collected. These wells will be located downgradient of the disposal cell and screened in the lower Tertiary gravels (the uppermost aquifer). The close proximity of the wells to the disposal cell will allow for early detection of any potential contaminant releases.

The location, proposed in the RAP, of one of the POC wells (GUN-08-0722) has been changed under the LTSP. The original location was at the northernmost tip of the disposal cell and thus crossgradient from the cell. Under the LTSP, POC well -0722 will be located about 300 feet $(90 \mathrm{~m})$ east-southeast of the northern tip of the cell (Plate 1 and Figure 2.6). This will place the well downgradient rather than crossgradient from the cell.

Existing wells GUN-08-0609 and -0716 will be the background ground water monitor wells (Plate 1). These wells will be monitored to detect any changes in ground water conditions that are unrelated to the disposal cell itself, such as changes in ground water elevations or ground water chemistry. Water analyses from these wells will be compared to water analyses obtained from the POC wells to detect any possible releases from the disposal cell into the uppermost aquifer. These two wells represent the higher TDS (well 609) and lower TDS (well 716) background ground water at the disposal cell (Section 2.5.2).

Water quality sampling of existing downgradient monitor wells GUN-08-0714, -0715 , and -0717 will not be part of long-term surveillance monitoring, and their periodic sampling will be discontinued upon implementation of this LTSP. These wells will not be monitored because the six POC wells provide sufficient coverage for compliance monitoring. Background water quality in monitor wells GUN-08-0707, -0708, -0663, and -0713 will not be included in the long-term surveillance monitoring because the background historical ground water quality has been sufficiently characterized.

As part of the LTSP, water levels will be routinely measured in selected wells located away from the disposal cells. Wells $-0710,-0712,-0709$, and -0714 will be used to monitor regional water level changes along a wide perimeter around the disposal cell. Wells $-0630,-0634,-0663$, and -0715 will be used to monitor regional changes in ground water closer to the disposal cell (Figure 2.6). The purpose is to monitor potential regional changes in water levels or hydrologic gradients that could influence ground water levels and flow beneath the cell. 


\section{Figure 2.6}

\section{Proposed Ground Water Monitoring Network}

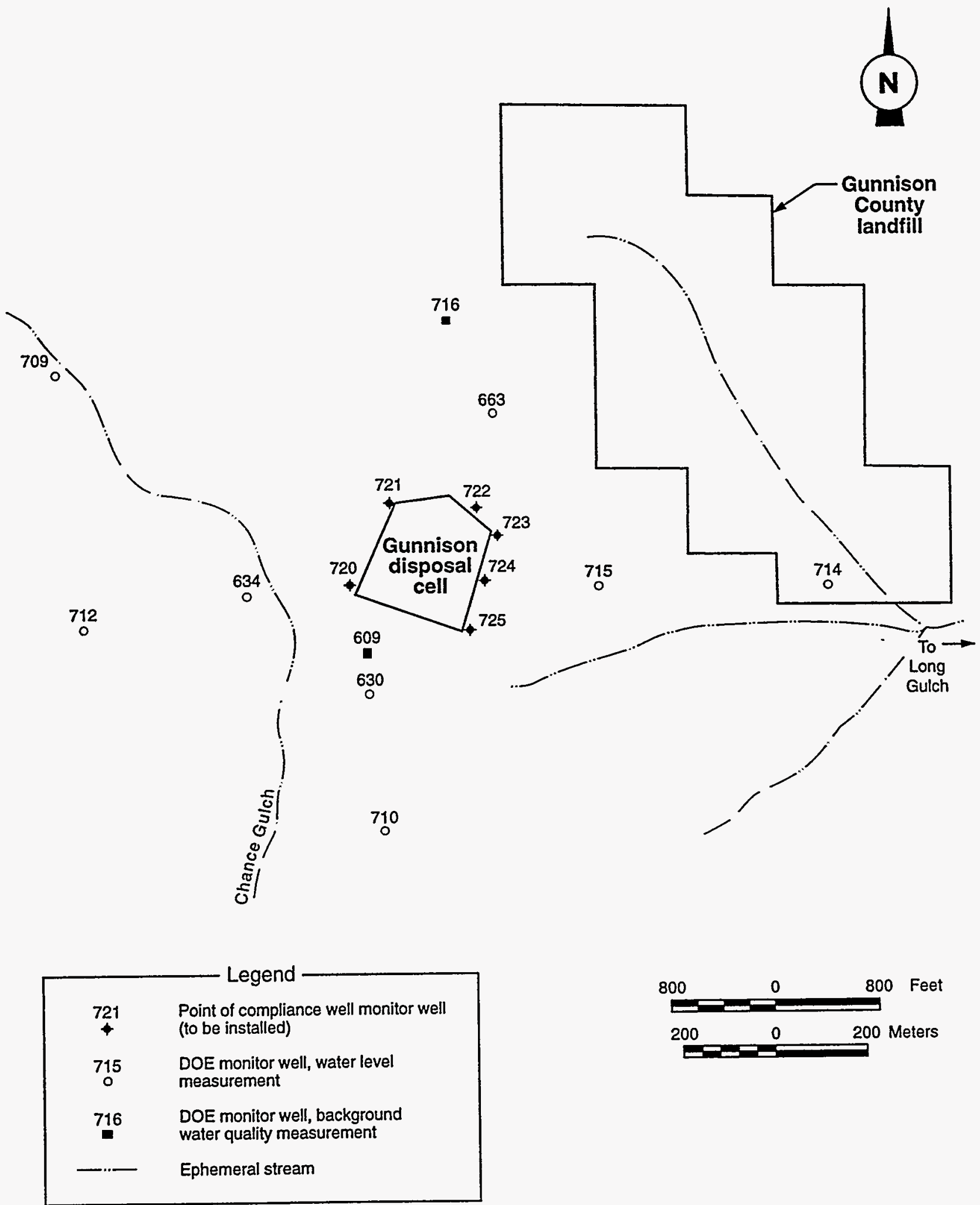

MAC: SITEGGUN/LTSPIPOC-GWNET 


\subsubsection{Concentration limits for hazardous constituents}

Concentration limits for long-term monitoring of the disposal cell (Table 2.3) were established following EPA guidance (EPA, 1992). In their guidance, the EPA endorses the use of tolerance intervals for detecting contamination above background in downgradient wells. A tolerance interval is designed to contain all but a small percentage of all future measurements from wells accessing uncontaminated water. Therefore, repeated exceedances of the upper tolerance limit present statistical evidence of contamination.

A nonparametric approach was used to determine a tolerance interval for the hazardous constituents of concern at the Gunnison site. Using this approach, the upper tolerance limit is the maximum observed concentration in water samples collected between 1988 and 1995 from selected wells completed in the uppermost aquifer (Table 2.2). Because the disposal cell is located in an area where the uppermost aquifer is influenced by two types of background ground water, it is appropriate to combine the data from both types for statistical analysis. Thus, at the Gunnison: site, the maximum concentrations are based on databases ranging from 51 measurements for thallium up to 73 measurements for arsenic, cadmium, chromium; lead, molybdenum, net gross alpha, radium226 and -228 , uranium, and zinc. There is 95 percent confidence the maximum observed concentration of each constituent represents a level that will exceed background no more than 5 percent of the time. Therefore, using the maximum observed concentration as a concentration limit for long-term ground water monitoring produces reasonable protection against false-positive results from random background variation.

Regulations allow the concentration limits for hazardous constituents listed in 40 CFR Part 192 to be set at the background concentrations or MCLs, whichever are greater. Therefore, the proposed concentration limits for hazardous constituents listed in Table 2.3 represent the larger of the maximum observed concentration and the UMTRA Project MCL for constituents with established MCLs. 
Table 2.3 Summary of water quality data and proposed concentration limits for hazardous constituents in tailings solutions, Gunnison, Colorado, disposal site

\begin{tabular}{|c|c|c|c|c|c|c|c|c|}
\hline \multirow[b]{2}{*}{ Constituent } & \multirow[b]{2}{*}{ MCL } & \multicolumn{3}{|c|}{ Tailings solutions } & \multicolumn{3}{|c|}{ Background $^{\mathrm{b}}$} & \multirow{2}{*}{$\begin{array}{c}\text { Proposed } \\
\text { concentration } \\
\text { limit }\end{array}$} \\
\hline & & $\begin{array}{l}\text { No. of } \\
\text { samples }\end{array}$ & Median & Maximum & $\begin{array}{c}\text { No. of } \\
\text { samples }\end{array}$ & Median & Maximum & \\
\hline \multicolumn{9}{|c|}{ Hazardous constituents with MCLs } \\
\hline Arsenic & 0.05 & 43 & 8.3 & 1,760 & 73 & 0.03 & 0.10 & $0.1^{c}$ \\
\hline Cadmium & 0.01 & 43 & 0.691 & 14.2 & 73 & $<0.001$ & 0.001 & 0.01 \\
\hline Chromium & 0.05 & 43 & 0.16 & 3.9 & 73 & $<0.01$ & 0.02 & 0.05 \\
\hline Lead & 0.05 & 42 & $<0.01$ & 1.9 & 73 & $<0.01$ & 0.03 & 0.05 \\
\hline Molybdenum & 0.10 & 43 & 0.27 & 12.5 & 73 & $<0.01$ & 0.04 & 0.10 \\
\hline Net gross alpha & 15 & 6 & 3,070 & 22,317 & 73 & 1.8 & 28 & $28^{c}$ \\
\hline Nitrate & 44 & 25 & 5.9 & 190 & 71 & $<1$ & 13 & 44 \\
\hline Radium-226, -228 & 5 & 5 & 16.2 & 843 & 73 & .0 .9 & .. 8.0 & $8^{c}$ \\
\hline Selenium $^{\mathrm{a}}$ & 0.01 & 44 & $<0.005$ & 60 & 70 & $<0.005$ & $<0.005$ & 0.01 \\
\hline Uranium & 0.044 & 42 & 0.81 & 190 & 73 & 0.002 & 0.027 & 0.044 \\
\hline \multicolumn{9}{|c|}{ Hazardous constituents without MCLs } \\
\hline Antimony & - & 34 & 0.018 & 0.156 & 58 & $<0.003$ & 0.012 & 0.012 \\
\hline Beryllium & - & 30 & 0.16 & 1.14 & 58 & $<0.005$ & $<0.01$ & $0.005^{b}$ \\
\hline Cobalt & - & 30 & 15.4 & 63.2 & 58 & $<0.05$ & $<0.05$ & $0.05^{b}$ \\
\hline Copper & - & 43 & 9.34 & 96 & 58 & $<0.02$ & $<0.02$ & $0.02^{b}$ \\
\hline Nickel & - & 43 & 15.4 & 99 & 58 & $<0.04$ & $<0.04$ & $0.04^{b}$ \\
\hline Thallium ${ }^{a}$ & - & 19 & 0.02 & 0.35 & 51 & $<0.005$ & $<0.1$ & $0.005^{b}$ \\
\hline $\operatorname{Tin}^{a}$ & - & 21 & $<0.005$ & 0.11 & 58 & $<0.005$ & $<0.05$ & $0.05^{b}$ \\
\hline Vanadium & - & 43 & 0.29 & 13 & 72 & $<0.01$ & 0.02 & 0.02 \\
\hline Zinc & - & 43 & 45.5 & 369 & 73 & 0.005 & 0.06 & 0.06 \\
\hline
\end{tabular}




\begin{tabular}{|c|c|c|c|c|c|c|c|c|c|}
\hline 蛋暠 & $\begin{aligned} \text { Table } 2.3 & \begin{array}{l}\text { Sumt } \\
\text { solut }\end{array}\end{aligned}$ & $\begin{array}{l}\text { wate } \\
\text { Innis }\end{array}$ & $\begin{array}{l}\text { uality dz } \\
\text { Colorad }\end{array}$ & $\begin{array}{l}\text { ta and prop } \\
\text { o, disposal }\end{array}$ & $\begin{array}{l}\text { d concentra } \\
\text { (Concluded) }\end{array}$ & limits $f$ & azardou & stituents & tailings \\
\hline - & & & & Tailings sol & ions & & Backgro & & Proposed \\
\hline & Constituent & MCL & $\begin{array}{c}\text { No. of } \\
\text { samples }\end{array}$ & Median & Maximum & $\begin{array}{c}\text { No. of } \\
\text { samples }\end{array}$ & Median & Maximum & $\begin{array}{c}\begin{array}{c}\text { concentration } \\
\text { limit }\end{array} \\
\end{array}$ \\
\hline & General water qu & licater & & & & & & & \\
\hline & Alkalinity & - & 2 & 89 & 136 & 72 & 162 & 255 & - \\
\hline & Calcium & - & 43 & 415 & 599 & 71 & 34 & 60 & - \\
\hline & Chloride & - & 24 & 27 & 210 & 71 & 9 & 31 & - \\
\hline & Iron & - & 43 & 1,760 & 61,100 & 73 & $<0.03$ & 0.22 & - \\
\hline & Lead-210 & - & - & - & - & 58 & 0.0 & 2.8 & - \\
\hline & Magnesium & - & 43 & 176 & 1,010 & 73 & 4 & 8 & - \\
\hline & Manganese & - & 43 & 38.5 & 197 & 51 & $<0.01$ & 0.3 & - \\
\hline & $\mathrm{pH}$ & - & 21 & 3,12 & 7.67 & 73 & 7.5 & 9.9 & - \\
\hline & Potassium & - & 43 & 5.5 & 79.1 & 73 & 6 & 17 & - \\
\hline & Sodium & - & 43 & 129 & 5,220 & 73 & 52 & 103 & - \\
\hline & Sulfate & - & 16 & 6,950 & 230,000 & 71 & 51 & 88 & - \\
\hline & TDS & - & 10 & 23,400 & 63,100 & 71 & 280 & 417 & - \\
\hline & 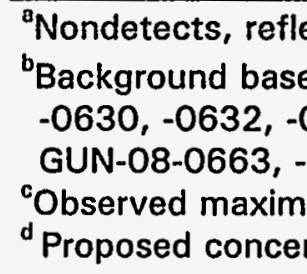 & $\begin{array}{l}\text { nflated } \\
\text { ata col } \\
0635, \\
-0704, \\
\text { kgrour } \\
\text { limit }\end{array}$ & $\begin{array}{l}\text { letection li } \\
\text { cted durin } \\
6637,-063 \\
0708,-07 \\
\text { greater th } \\
t \text { at contra }\end{array}$ & $\begin{array}{l}\text { nit due to } m e \\
\text { the period } F \\
8 \text {, and }-0639 \\
6 \text {, and }-071 \\
\text { an MCL. } \\
\text { ct-required d }\end{array}$ & $\begin{array}{l}\text { interference, } \\
\text { uary } 1988 \text { th } \\
\text { nd during Feb } \\
\text { tion limit. }\end{array}$ & $\begin{array}{l}\text { ere remov } \\
\text { gh April 1 } \\
\text { ry } 1991 \text { th }\end{array}$ & $\begin{array}{l}\text { rom dat } \\
\text { from w } \\
\text { gh Octo }\end{array}$ & $\begin{array}{l}\text { for calcula } \\
\text { UN-08-060 } \\
995 \text { from w }\end{array}$ & $\begin{array}{l}\text { ls. } \\
\text { s. }\end{array}$ \\
\hline 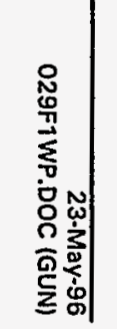 & $\begin{array}{l}\text { Note: All units re } \\
\text { liter. } \\
\text { MCL - maximum }\end{array}$ & $\begin{array}{l}\text { in milli } \\
\text { tration }\end{array}$ & $\begin{array}{l}\text { rams per li } \\
\text { imit. }\end{array}$ & er except rac & $n-226$ and -22 & and net $\mathrm{g}$ & alpha wl & re reported & picocuries per \\
\hline
\end{tabular}




\subsection{SITE INSPECTIONS}

The DOE will conduct routine inspections of the Gunnison disposal site to detect progressive change caused by slow-acting natural processes and to identify potential problems before the need for extensive maintenance, repairs, or corrective action. Nonroutine inspections also will be conducted to follow up on reports of events or conditions that have affected or potentially could affect the disposal site. The DOE will compare the findings from these inspections to initial baseline conditions to identify any changes over time and to provide a basis for future inspections, repairs, and corrective actions.

Site inspections will be thoroughly documented. After each inspection, the DOE will prepare a report for the NRC that records the findings of the inspection and that clearly identifies any adverse impacts or threats to the disposal cell.

\section{$3.1 \quad$ INSPECTION FREQUENCY}

The DOE will inspect the Gunnison disposal site annually. The DOE may schedule more frequent inspections at any time should the need arise. For example, the DOE may schedule a separate inspection of site vegetation if the annual site inspection did not coincide with the general growing season. The DOE will notify the NRC of the inspection schedule.

\subsection{INSPECTION TEAM}

The inspection team will consist of a minimum of two inspectors qualified to inspect disposal cell integrity and make preliminary assessments of modifying processes that could adversely affect the disposal cell. A plant specialist may also participate in inspections to evaluate the adequacy of the revegetation at the disposal site.

Follow-up inspection teams will include one or more technical specialists in appropriate disciplines to assess the problem(s) under investigation. For example, a follow-up inspection by a plant specialist may be required to evaluate reports of significant plant growth on the rock cover or a soils scientist or geomorphologist may be needed to evaluate erosion processes.

\subsection{SITE INSPECTION PROCEDURES}

Before each inspection, inspectors will perform a readiness review. The longterm surveillance program guidance (DOE, 1996) contains information useful in preparing for inspections.

Site inspections will cover the disposal cell, the surrounding disposal site area, and the immediate off-site areas. Site inspections must be thorough enough to identify any significant changes or active modifying processes that could potentially adversely affect the disposal cell. Surveillance should be performed 
to identify unanticipated effects of modifying processes such as gully formation, slope erosion, changes to the rock cover, ephemeral drainage channel changes, and significant modifications by humans, animals, or plants. Site-specific concerns include future expansion of the Gunnison County landfill, and potential breaking down of erosion protection rock due to freeze-thaw effects.

Inspectors will evaluate the integrity of the disposal cell by walking a series of transects around the perimeter and over the rock cover. Sufficient transects, at approximately $150-\mathrm{ft}(46-\mathrm{m})$ intervals, must be walked so that the disposal cell is thoroughly covered and inspected. Diagonal transects of the topslopes will be made and the crest line will be walked. Additional transects will be walked along the sideslopes and rock apron. Transects along the entire length of the diversion ditch will be made to determine whether it is functioning as designed and can be expected to continue to function properly. Inspectors will review transect paths from previous inspections and make efforts to vary the path of transects from one inspection to the next to ensure small anomolies are not overlooked. The sample inspection checklist (DOE, 1996) lists items that should be examined during inspections. During transects over Types $B, C$, and $D$ riprap, inspectors will check for evidence of potential deterioration (i.e., breakdown) of the larger rock particles, including cracking, spalling, or slabbing lalong fracture planes).

Special care must be taken to avoid misinterpretation of as-placed conditions. As-placed riprap particles will have, to a minor degree, the characteristics listed above. The key in evaluating whether or not freeze-thaw is affecting the riprap will be progressive, future deterioration of representative particles (not just minor amounts of particles with as-placed defects). Any particles that previously appeared sound and intact that deteriorate over time will be reported and will be reinspected during future monitoring.

The disposal cell has a rock cover and there is no planned vegetation on the disposal cell. However, remedial action of the areas surrounding the disposal cell included revegetation with grasses. The area surrounding the disposal cell will be monitored to determine the success of the revegetation efforts. Inspectors also will inspect this area for evidence of erosion caused by wind, sheet wash, or changes in drainage patterns.

Site inspections also will monitor damage to or disturbance of permanent sitesurveillance features, ground water monitor wells, fencing, gate, and locks.

From inside the disposal site, inspectors will visually survey the area within a maximum of $0.25 \mathrm{mi}(0.40 \mathrm{~km})$ from the boundary of the disposal site for evidence of land-use changes that indicate increased human activity such as land development or new roads and paths. Inspectors will note the condition of and changes to site access roads, surrounding vegetation, and relevant geomorphic features like gullies or ephemeral drainage channels; potential impacts to the site will be noted. Off-site DOE monitor wells will be inspected until they are properly abandoned. 
All site inspections will be conducted in accordance with a DOE-approved safety and health plan.

\subsection{FOLLOW-UP INSPECTIONS}

DOE will conduct follow-up inspections to investigate and quantify specific problems found during a previous inspection, other DOE-initiated activity, or other confirmed reports of vandalism, intrusion, damage, or other significant threat to the disposal site. Notifications of severe rainstorms, flash floods, or unusual events such as tornadoes or earthquakes in the vicinity of the Gunnison site also can trigger follow-up inspections. Follow-up inspections will be conducted to determine whether processes currently active at or near the site threaten site security or stability and to evaluate the need for custodial maintenance, repair, or other corrective action. The scope of these follow-up inspections may be broad and similar in nature to routine site inspections or focused on specific areas of concern.

A follow-up inspection usually will begin with an on-site visit by technical specialists to confirm whether or not the disposal cell has been damaged or to determine the need for more definitive tests or studies. The DOE will schedule additional site visits if more data are needed to draw conclusions and to recommend repairs or corrective action.

\subsection{QUALITY ASSURANCE}

The DOE has developed and implemented a quality assurance plan (DOE, 1992c) for the site inspection program that meets the requirements of DOE Order 5700.6C. All site inspections will be conducted in accordance with this quality assurance plan.

\subsection{SITE INSPECTION DOCUMENTATION}

During site inspections, all activities and observations will be recorded and described using a site inspection checklist, site inspection map, photographs and photo log, and field notes. Documentary evidence of anomalous, new, or unexpected conditions or situations must describe developing trends and enable the DOE to make decisions concerning follow-up inspections, custodial maintenance, and corrective action. The DOE will prepare a site inspection report documenting the findings and recommendations from each field inspection.

\subsubsection{Site inspection checklist}

The sample site inspection checklist (DOE, 1996) is a guide for the inspectors to prepare for and conduct site inspections. Inspectors will prepare a site-specific checklist that addresses the features to be inspected and monitored at the Gunnison disposal site. All checklist items should be completed. Annotations 
-... should be made on the checklist to add more detailed information. All entries must be clearly stated and legible because the completed checklist becomes part of the permanent field record of the inspection. Upon completion of the inspection, the lead inspector must sign a statement certifying the scope of the inspection.

After each inspection is complete, the checklist may be revised, if necessary, to include new information or to delete items that are no longer pertinent. Revisions to the checklist will be documented in the inspection report.

\subsubsection{Site inspection maps}

Plate 1 will serve as the baseline.for preparing the site inspection map. The inspection team will annotate copies of the site inspection map during site inspections. The annotated site inspection map must include the following information:

- Inspection traverses.

- Photographic locations.

- Locations and descriptions of any new, anomalous, or unexpected features.

- Features identified during previous inspections for observation or monitoring.

- Inspection date and type of inspection.

\subsubsection{Site inspection photographs}

A photographic record of the site inspection must be maintained. Site conditions should be documented by ground photographs to record developing trends and to enable the DOE to make decisions concerning additional inspections, custodial maintenance or repairs, or corrective action. If possible, any site feature or condition requiring inspectors to make a written comment, explanation, or description will be photographed. A site inspection photo log will be used to record the photographs. A separate photo log should be completed for each roll of exposed film, with an entry for each photograph.

At a minimum, the site features listed in the long-term surveillance guidance (DOE, 1996) should be documented with photographs during site inspections. In addition, any new or potential problem areas identified during a site inspection must be well documented with photographs. All site inspection photographs, as well as all corresponding photo log forms, will be maintained in the permanent site file.

\subsubsection{Field notes}

The inspection team will use field notes to record observations made during the . inspection but not recorded on the inspection checklist or inspection map. The field notes will become part of the permanent site file. 


\subsubsection{Site inspection report}

After every site inspection, the DOE will prepare a site inspection report that discusses scope of the inspection, observations made, and conclusions drawn from the inspection. At a minimum, the inspection report will include

- Description of the site conditions.

- Completed site inspection checklists and any relevant supporting documentation, including names and qualifications of the field inspectors.

- Site inspection map and other relevant drawings, maps, or figures.

- Inspection photographs and photo logs.

- Conclusions and recommendations for follow-up inspections, custodial maintenance, or repairs, if required.

- Custodial maintenance or repair report and certification, if any was performed.

If new conditions requiring monitoring or immediate action are discovered during the inspection, the inspection report will detail any observed modifying features and will include a description of the problem, relevant measurements and photographs, and an impact assessment. The description of the modifying process will include information such as the following:

- Extent of area affected.

- Number, spacing, and size of féatures (e.g., gullies).

- Locations and patterns of occurrence.

- Species, location, and density of volunteer plant growth.

Evidence of deliberate and repeated human intrusion such as cover removal, extensive vandalism to signs and monuments, or the presence of well-established trails will be described in detail. All signs of vandalism will be noted since evidence of continued vandalism may indicated the need to implement more active measures to control site access.

The results of all follow-up inspections shall be documented in written reports. Other appropriate documentation such as photographs, measurements, and drawings shall be included. At a minimum, a follow-up inspection report must include the following:

- Description of the problem and preliminary assessment of impact.

- Conclusions and recommendations for custodial maintenance, repair, or corrective action required. 
- Assessment data, photographs, and supporting documentation.

A copy of all site inspection reports and supporting documentation will be maintained in the permanent site file. 


\subsection{GROUND WATER MONITORING}

The DOE evaluated the need for ground water monitoring at the Gunnison disposal site in accordance with the licensing regulations at 10 CFR $\$ 40.27(b)(2)$, the ground water protection standards at 40 CFR Part 192, Subparts $A$ and $C$, and the DOE's long-term surveillance program guidance (DOE, 1996). POC monitoring is required for the long-term surveillance program at the Gunnison disposal site to comply with the ground water protection standards at 40 CFR $\$ 192.03$ to demonstrate disposal cell performance.

\subsection{GROUND WATER MONITORING PLAN}

The ground water protection monitoring plan includes sampling and analyzing ground water from a series of monitor wells downgradient from the disposal cell at the POC and upgradient or crossgradient from the disposal cell as background (Section 2.6.1). The long-term monitoring strategy is to sample the direct monitor well network at prescribed intervals for water levels and a set of screening parameters. Should screening monitoring indicate that there is a potential release from the disposal cell, evaluative ground water monitoring will be conducted to determine the nature of the exceedance. The direct monitor well network and performance monitoring frequency are discussed below. Potential indirect monitoring techniques that may be used, if it is determined they are necessary, are discussed in Section 4.1.6.

\subsubsection{Direct ground water monitoring network}

Ground water samples will be collected from six POC wells downgradient of the disposal cell. Sampling will be performed to measure ground water quality and static water levels at the $\mathrm{POC}$, direetly downgradient of the disposal cell in the uppermost aquifer. The six POC wells will be located approximately $50 \mathrm{ft}$ $(15 \mathrm{~m})$ from the disposal cell (Plate 1). Placement of the POC monitor wells optimizes early detection of any hazardous constituents released in the uppermost aquifer without disturbing the design components of the cell. The $P O C$ wells will be installed into the uppermost aquifer.

Ground water quality and water level data will also be monitored in two background wells, wells GUN-08-0609 upgradient and well GUN-08-0716 crossgradient from the disposal cell. These wells are screened in the same aquifer as the POC wells and at approximately the same depth. The background well will be sampled at the same frequency as the POC wells and will be monitored for the same constituents. Water levels will also be measured in 8 wells away from the disposal cell to monitor potential changes in regional hydrologic conditions (Section 2.6.1).

\subsubsection{Sampling frequency}

The schedule for sampling takes into account such factors as background ground water quality, the geochemistry of the tailings pore fluid solution, horizontal and 
vertical ground water flow rates, the possibility of seasonal variations in ground water, and risk to human health and the environment. Ground water levels will be measured before each well is sampled. Monitor wells at the Gunnison disposal cell have been sampled annually or semiannually since 1988. During construction of the cell and placement of tailings, monitor wells were sampled semiannually (in the early summer and fall).

The long-term surveillance monitor well network will be sampled according to the sampling schedule in Table 4.1.

Table 4.1 Sampling schedule for the monitor well network at the Gunnison, Colorado, disposal site

\begin{tabular}{|c|c|c|}
\hline $\begin{array}{l}\text { Years after POC } \\
\text { well completion }\end{array}$ & $\begin{array}{c}\text { Number of sampling } \\
\text { events }\end{array}$ & Time of sampling \\
\hline 1 & 2 & Fall and early summer \\
\hline 2 & 1 & Early summer \\
\hline 3 & 1 & Early summer \\
\hline 4 & 1 & Early summer \\
\hline 5 & 1 & Early summer \\
\hline $10^{a}$ & 1 & Early summer \\
\hline
\end{tabular}

The monitor well network will be sampled twice in the first year after POC well completion (fall, 1996 and early summer, 1997). These two sampling rounds during the first year will determine if water quality in each POC well is stable and representative of baseline conditions. Sampling will be conducted in the fall and early summer to maintain a consistent record in the historical database.

Sampling will be conducted annually the second through fifth years (1998 through 2000) after POC well installation. These data will establish a baseline for each POC well. It is expected that each POC well will be representative of one of the two types of ground water observed in background. Sampling will be conducted in the early summer to coincide with the expected time of greatest potential ground water recharge.

A sampling frequency of once every 5 years is recommended, starting with sampling on the tenth year following POC well installation. These sampling frequencies are recommended at the disposal cell for the following reasons: 
- The average water level in the uppermost aquifer beneath the disposal cell is approximately $110 \mathrm{ft}(34 \mathrm{~m}$ ) below land surface (DOE, 1992b),

- Background water quality in the uppermost aquifer beneath the disposal cell is well established (Section 2.6.2),

- The disposal cell design minimizes infiltration through the cover; the tailings were placed into the disposal cell at a moisture content designed to produce almost no transient drainage (DOE, 1992b),

- Geochemical investigations conducted during preparation of the RAP (DOE, 1992b) determined that geochemical characteristics of the foundation materials are favorable in attenuating seepage of hazardous constituents in tailings from the base of the disposal cell, and

- Ground water use is limited in the disposal cell vicinity. Only one private well is known to be located downgradient of the disposal cell (DOE, 1992b). This well is located approximately $7500 \mathrm{ft}(2390 \mathrm{~m})$ from the disposal cell. Using the estimated ground water velocity within the Tertiary gravel aquifer of approximately $7 \mathrm{ft}$ per year $\left(7 \times 10^{-6} \mathrm{~cm}\right.$ per second) (Calculation No. GUN-05-90-14-07-02), it would take over 1000 years for any potential contamination from the disposal cell to reach this well.

This frequency may be changed, upon approval from the NRC, based on sitespecific conditions and the effectiveness of disposal cell performance as determined through the ongoing monitoring program.

\subsubsection{Ground water monitoring team}

Water samples will be collected by a team consisting of, at a minimum, two water sampling technicians. The technicians will be knowledgeable in the general principles of ground water sampling techniques. Personnel will be required to follow a set of standard operating procedures or industry accepted standards, such as American Society for Testing and Materials standards, under strict quality assurance/quality control standards designed to produce ground water analyses that are defensible and representative of ground water conditions. Collected data will be evaluated by a technical specialist experienced in the interpretation of hydrogeological data.

\subsubsection{Screening monitoring and exceedance validation}

During the established ground water monitoring period, screening monitoring will be conducted to observe possible changes in ground water quality and to assess compliance with the ground water protection standards. Screening monitoring includes routine water-quality data collection, data evaluation, and possible resampling. It also includes analyzing constituents that are indicative of general water quality and hazardous constituents that are reliable indicators of 
contamination (Table 4.2). General water quality indicators include $\mathrm{pH}$, electrical conductivity, temperature, alkalinity, oxidation-reduction potential, and major anions and cations. These data provide general information for interpreting potential changes in ground water quality. Screening parameters indicative of contamination are those that 1) are known to be present in the tailings solutions at levels statistically greater than background levels, 2) are present at much higher levels in the tailings solutions than in background, 3) display low variability in background, and 4) are mobile in the ground water environment. The parameter that best meets these criteria is uranium.

Exceedances in concentration limits for uranium are evaluated on a well-by-well basis. If the screening monitoring action level for uranium listed in Table 4.2 is exceeded, the well will be resampled within 1 year for all screening monitoring parameters listed in Table 4.2. If the resampling indicates a second exceedance or if changes in other monitored constituents or wells are observed that clearly support the inference that contamination from the disposal cell is reaching ground water in excess of the deșign standards, then the monitoring program will enter into the evaluative monitoring phase. The DOE will notify the NRC of this event and that an evaluative monitoring work plan is being prepared.

\subsubsection{Evaluative monitoring}

When sampling, evaluating, and resampling during screening monitoring does not eliminate the disposal cell as the cause for a water-quality exceedance, evaluative ground water monitoring, additional evaluation, and fieldwork may be required. The purpose of evaluative monitoring is to determine with greater surety whether the disposal cell is directly or indirectly contributing to the observed exceedances, and if so, to isolate the probable contributing source and assess the current and potential future impacts to ground water.

Evaluative ground water monitoring will involve sampling ground waters from POC and possibly other wells, and analyzing for the entire suite of hazardous constituents identified in Table 2.3 to determine if any hazardous constituents exceed the proposed concentration limits. Data and fieldwork will be evaluated further to determine if the disposal cell is the cause of an exceedance and if so, its nature and extent. The DOE will submit the evaluative monitoring work plan to the NRC for review prior to initiating the evaluative monitoring program. Additional details concerning an evaluative monitoring work plan are presented in the long-term surveillance program guidance (DOE, 1996). 
Table 4.2 Parameters to be measured during screening monitoring at the Gunnison, Colorado, disposal site

\begin{tabular}{ll}
\hline \multicolumn{1}{c}{ Parameter } & \multicolumn{1}{c}{$\begin{array}{c}\text { Proposed screening } \\
\text { monitoring action level }\end{array}$} \\
\hline $\begin{array}{l}\text { Indicator parameter for detecting ground water contamination } \\
\text { Uranium }\end{array}$ & $0.027^{\mathrm{a}}$ \\
Field parameters for monitoring ground water quality & \\
Alkalinity & None \\
Oxidation-reduction potential & None \\
pH & None \\
Specific conductivity & None \\
Temperature & None \\
Major anions and cations for monitoring ground water quality & \\
Calcium & None \\
Chloride & None \\
Iron & None \\
Magnesium & None \\
Manganese & None \\
Potassium & None \\
Sodium & None \\
Sulfate & None \\
TDS & None \\
\hline Proposed acton & N \\
\hline
\end{tabular}
${ }^{8}$ Proposed action level is in milligrams per liter and is based on maximum observed background
value. 


\subsubsection{Indirect monitoring}

As stated above, the DOE will directly monitor ground water at the disposal site. If screening and evaluative monitoring indicate a change in ground water quality attributable to the disposal cell design, the need for indirect monitoring will be assessed.

If evaluative monitoring indicates the performance of the disposal cell is the cause of an exceedance, it may be necessary to monitor the cover, the tailings, the subsoils, or a combination of components. Some indirect methods that may be applicable to monitoring changes in moisture content in the disposal cell include core sampling to determine gravimetric water content, neutron moisture probe monitoring, time-domain reflectometry, heat dissipation probes, or crosshole topography. Any indirect monitoring instrumentation that may be required will be installed in accordance with the appropriate standard operating procedures or best management practices.

Specific monitoring strategies and instrumentation will be selected in consultation with the NRC.

\subsection{DATA VALIDATION AND QUALITY ASSURANCE}

All aspects of the ground water monitoring plan will be conducted in accordance with accepted industry quality assurance practices, including DOE directives in DOE Order $5700.6 \mathrm{C}$, and will be consistent with EPA ground water monitoring guidance (EPA, 1986).

The DOE has established standard operating procedures for monitor well installation and development, water and soil sampling, sample preservation and transport, field procedures, chain-of-custody samples for laboratory analyses, acquisition protocols, and validating and managing analytical data. All aspects of ground water monitoring are conducted in accordance with these procedures, which are updated regularly to reflect changes in industry standards, best management practices, and guidance from the DOE or EPA.

\subsection{GROUND WATER MONITORING DOCUMENTATION}

Hard copies of reports of ground water data collected during the long-term surveillance monitoring program will be stored in the permanent site file; the ground water data will also be stored in the DOE ground water quality database along with historical ground water quality data for the Gunnison site.

Once every 5 years, the DOE will describe the data and results of the ground water monitoring program in an evaluation report to the NRC. The 5-year report will include the following information:

- Water quality data, water level data, and other data collected during the reporting period. 
- A table comparing water quality indicators to concentration limits.

- A summary of exceedances of concentration limits and the exceedance validation criteria.

- A summary of all resampling, evaluative monitoring, indirect monitoring, or corrective action required during the reporting period.

- A discussion of significant trends or anomalies in the water quality, other data, or changes in the local hydrologic setting.

- A discussion of new wells or indirect monitoring stations that were installed, including the rationale for their installation, and all completion data.

- All completed field and laboratory forms. 


\subsection{CUSTODIAL MAINTENANCE OR REPAIR}

The DOE does not plan to conduct routine maintenance at the Gunnison disposal site. However, the DOE will perform needed custodial maintenance or repair as determined from site inspections. The DOE will prepare a statement of work that will include qualifications of the maintenance/repair contractor and certify all custodial maintenance and repair work performed at the Gunnison disposal site.

Unscheduled custodial maintenance or repair required at the Gunnison disposal site may include the following:

- Repairing or replacing deteriorated or vandalized warning signs, fencing, gate, locks, and monitor well caps.

- Removing volunteer plant growth from riprap-covered areas.

- Reseeding areas surrounding the disposal cell.

If repairs are needed to address problems that may affect the integrity of the disposal cell or compliance with 40 CFR Part 192, the NRC must approve the recommended action in advance. Such action will be treated as a corrective action (see Section 6.0).

After the work is completed, the maintenance/repair contractor must submit written verification of the completed work. The DOE will inspect the site, as necessary, and review the report before certifying that all work is completed in accordance with all required specifications.

The annual report to the NRC must include the following information on unscheduled maintenance or repair:

- Work order, purchase order, or statement of work.

- Contractor documentation of work completion.

- DOE certification of work completion.

Copies of all records, reports, and certifications will be included in the permanent site file. 


\subsection{CORRECTIVE ACTION}

Site inspections and ground water monitoring are designed to identify problems at the developmental stage. Examples of conditions that might trigger corrective action are

- Surface rupture or subsidence of the disposal cell.

- Development of rills or gullies or slope instability on the disposal cell.

- Deterioration of the erosion protection rock on the disposal cell.

- Exceedance of ground water concentration limits at POC wells.

- Seepage originating from the disposal cell.

- Gully development on or immediately adjacent to disposal site property that could affect the integrity of the disposal cell.

- Damage to the cell cover or disposal site property from natural catastrophic events or vandalism.

- Evidence of hazardous material spills near monitor wells.

- Damage to the disposal cell cover from deep-rooted plant growth.

The DOE will evaluate the factors that caused the problem and identify actions to mitigate the impact and prevent recurrence. An on-site inspection or preliminary assessment would include, but is not limited to, the following:

- Identifying the nature and extent of the problem.

- Reevaluating germane engineering design parameters.

- Establishing a data collection and/or evaluative monitoring program to determine or confirm the cause of an exceedance of ground water concentration limits.

When a potential problem is identified, the DOE will submit a preliminary assessment report to the NRC for review no more than 60 days after the problem is identified. The preliminary assessment report will evaluate the problem and recommend the next step (e.g., immediate action or continued evaluation). After the NRC reviews the report and recommendations, the DOE will develop a corrective action plan for NRC approval. Once the NRC approves the corrective action, the DOE will implement the plan. In some cases, corrective action could include temporary emergency measures taken prior to the completion of the normal approval process. In cases where the corrective action is in response to an exceedance of the ground water standards, the plan will include a 
monitoring plan to demonstrate the effectiveness of the corrective action, which the DOE will implement after consultation with the NRC.

NRC regulations do not stipulate a time frame for implementing corrective action.

However, 40 CFR §192.04 requires that a corrective action program begin within 18 months after a finding of an exceedance in established ground water concentration limits. The DOE does not consider assessing the extent of a problem and developing a corrective action plan to be initiation of the corrective action program.

In addition to the preliminary assessment report, the DOE may prepare progress reports on each corrective action while it is under way or under evaluation.

After corrective action is complete, the DOE will certify all work and submit a certification statement and supporting documentation to the NRC for review and concurrence. A copy of the certification statement will become part of the permanent site file, as will all reports, data, and documentation generated during the corrective action. 


\subsection{EMERGENCY NOTIFICATION AND RESPONSE}

To ensure the timely investigation of potential problems affecting the disposal cell, the DOE has requested notification from federal, state, and local agencies of discoveries or reports of any purposeful intrusion or damage at the disposal site as well as the occurrence of earthquakes, tornadoes, or floods in the disposal site area.

The DOE is negotiating notification agreements with the Gunnison County Sheriff's Office, the U.S. Geological Survey's National Earthquake Information Center, and the Colorado area office of the National Weather Service (Attachment 2). These agreements will trigger notification of the more probable occurrences that could cause an emergency response. In addition, the DOE 24-hour phone number is posted on the site entrance sign so the public can notify the DOE if problems are discovered.

The nature of the occurrence and the amount of first-hand knowledge available will determine the DOE's response. If an emergency situation poses an immediate threat to the public, the DOE will notify individuals who may be affected and appropriate federal, state, and local agencies, including the NRC. The DOE will take appropriate response action and advise the affected individuals of precautions that should be taken.

In all cases, the notification, response, and any follow-up activities shall be documented. This documentation will become part of the permanent site file. Discussions of emergency notifications and responses also will be included in the annual site report to the NRC. 


\subsection{RECORD KEEPING AND REPORTING}

The DOE will maintain a permanent site file containing site inspection reports and other supporting documentation of long-term surveillance program activities. The information placed in the site file will include:

- Documentation of disposal site performance.

- Demonstration that licensing provisions were met.

- Information needed to forecast future site surveillance and monitoring needs.

- Reports to stakeholders regarding disposal cell integrity.

After the site is brought under the general license, the DOE will compile copies of site documentation required by the long-term surveillance program guidance (DOE, 1996) for the Gunnison disposal site permanent site file. Copies of all deeds, custody agreements, and other property documents will be kept in the site file.

The surveillance and maintenance documentation identified in other sections of this LTSP will be maintained by the DOE and become part of the permanent site file. The DOE will update the site file as necessary after disposal site inspections, maintenance activities, or corrective actions are complete. These records will be handled in accordance with DOE directives to ensure their proper handling, maintenance, and disposition. The archival procedures set forth in 41 CFR Part 101 and 36 CFR Parts 1220-1238 (Subchapter B) will be followed. All information will be available for NRC and public review.

The DOE will prepare an annual report documenting the results of site inspections and any other activities conducted in conjunction with the long-term surveillance program (Section 3.6.5). In accordance with 10 CFR Part 40 requirements, the annual report will be submitted to the NRC no more than 90 days after the date of the last UMTRA Project site inspection for that calendar year. This submittal will also include reports on any follow-up inspections and custodial maintenance or repairs performed during the year.

Following any inspection where unusual damage or disruption is discovered at the Gunnison disposal site, a preliminary report assessing the impact must be submitted to the NRC within 60 days of the initial discovery of the problem. If maintenance or repair or corrective action is warranted, the DOE will notify the NRC. The NRC will receive a copy of corrective action plans and each corrective action progress report, or the reports will be attached to the annual report.

In addition to the annual inspection report, every 5 years the DOE will submit an evaluation report to the NRC with the results of the ground water monitoring program.

The DOE will provide copies of inspection reports and other reports generated under the long-term surveillance program to the state of Colorado as dictated in their cooperative agreement. 


\subsection{REFERENCES}

Davis, S. N., and R. DeWiest, 1966. Hydrology, John Wiley \& Sons, Inc., New York, New York.

DOE (U.S. Department of Energy), 1996. Guidance for Implementing the Long-Term Surveillance Program for UMTRA Project Title I Disposal Sites, DOE/AL-62350189, Rev. 0, prepared for the U.S. Department of Energy, Environmental Restoration Division, UMTRA Project Team, Albuquerque, New Mexico.

DOE (U.S. Department of Energy), 1994. Baseline Risk Assessment of Ground Water Contamination at the Uranium Mill Tailings Site Near Gunnison, Colorado, DOE/AL-62350-57D, Rev. 1, prepared for the U.S. Department of Energy, UMTRA Project Office, Albuquerque Operations Office, Albuquerque, New Mexico.

DOE (U.S. Department of Energy), 1992a. Environmental Assessment of Remedial Action at the Gunnison Uranium Mill Tailings Site Near Gunnison, Colorado, DOE/EA0376, prepared for the U.S. Department of Energy, UMTRA Project Office, Albuquerque Operations Office, Albuquerque, New Mexico.

DOE (U.S. Department of Energy), 1992b. Remedial Action Plan and Site Conceptual Design for Stabilization of the Inactive Uranium Mill Tailings Site at Gunnison, Colorado, UMTRA-DOE/AL-050508.0000, prepared for the U.S. Department of Energy, UMTRA Project Office, Albuquerque Operations Office, Albuquerque, New Mexico.

DOE (U.S. Department of Energy), 1992c. Long-Term Surveillance and Maintenance Program Quality Assurance Program Plan, P-GJPO-152, prepared by Chem Nuclear Geotech, Inc., for the U.S. Department of Energy, Grand Junction Projects Office, Grand Junction, Colorado.

EPA (U.S. Environmental Protection Agency), 1992. Addendum to Interim Final Guidance Statistical Analysis of the Ground-Water Monitoring Data at RCRA Facilities, Office of Solid Waste, U.S. Environmental Protection Agency, Washington, D.C.

EPA (U.S. Environmental Protection Agency), 1986. RCRA Ground Water Monitoring Technical Enforcement Guidance Document, OSWER Directive 9950.1, Office of Solid Waste and Emergency Response, U.S. Environmental Protection Agency, Washington, D.C.

Freeze, R. A., and J. A. Cherry, 1979. Ground Water, Prentice-Hall, Inc., Englewood Cliffs, New Jersey. 
MK-ECE (Morrison Knudsen Corporation - Engineering, Construction, \& Environmental Groupl, 1995. UMTRA Project, Gunnison, Colorado, Surveillance and Maintenance Subcontract Documents - Final Design for Review, prepared by MKECE for the U.S. Department of Energy, Environmental Restoration Division, UMTRA Project Team, Albuquerque, New Mexico.

MK-F (Morrison Knudsen-Ferguson), 1996. Gunnison, Colorado, Draft Completion Report, prepared by MK-F for the U.S. Department of Energy, Environmental Restoration Division, UMTRA Project Team, Albuquerque, New Mexico.

\section{CODE OF FEDERAL REGULATIONS}

10 CFR Part 40, Domestic Licensing of Source Material, U.S. Nuclear Regulatory Commission.

36 CFR Parts 1220-1238, National Archives and Records, Subchapter B - Records Management, National Archives and Records Administration.

40 CFR Part 192, Health and Environmental Protection Standards for Uranium and Thorium Mill Tailings, U.S. Environmental Protection Agency.

41 CFR Part 101, Federal Property Management Regulations, General Services Administration.

\section{DOE ORDERS}

Order 5700.6C, Quality Assurance, 21 August 1991, U.S. Department of Energy, Washington, D.C.

\section{UNITED STATES CODE}

42 USC $\$ 7901$ et seq., Uranium Mill Tailings Radiation Control Act, 8 November 1978. 
ATTACHMENT 1

SITE REAL ESTATE INFORMATION 


\section{SITE REAL ESTATE INFORMATION}

The Uranium Mill Tailings Radiation Control Act (UMTRCA) of 1978, as amended, requires the Secretary of Energy to permanently acquire lands needed to carry out the purposes of the UMTRCA. The area the U.S. Department of Energy (DOE) selected for the Gunnison disposal site was located on public land being administered by the U.S. Department of the Interior's Bureau of Land Management (BLM).

\section{TRANSFER OF ADMINISTRATION OF THE DISPOSAL SITE}

Under the authority vested in the Secretary of the Interior by the UMTRCA, the BLM transferred administration of approximately 115 acres (ac) (47 hectares [ha]) of public land in Gunnison County, Colorado, to the DOE to use for the Gunnison disposal site via Public Land Order 6931. As a result of this permanent transfer, the land is longer subject to the operation of the general land laws, including the mining and mineral leasing laws. The transfer of the land vested in the DOE the full management, jurisdiction, responsibility, and liability for the land and all activities conducted thereon, except that the Secretary of the Interior retains the authority to administer any claims, rights, and interests in the land established before the effective date of the transfer.

\section{LEGAL DESCRIPTION}

Public Land Order 6931 was published in the Federal Register on 15 June 1992, the effective date of the transfer. The attached copy of the order (57 FR 26607) contains a legal description of the land transferred to the DOE.

The final disposal site will only comprise approximately 92 ac ( $37 \mathrm{ha}$ ) of the original 115 ac $(47 \mathrm{ha})$. The DOE will include the legal description of the final disposal site boundaries in this attachment after the final site survey is completed. 
CHAPTER 101-FEDERAL PROPERTY MANAGEMENT REGULATIONS

SUBCHAPTER G-AVIATION, TRANSPORTATION, AND MOTOR VEHICLES

Appendix to Subchapter G-Temporary Regulations

[FPMR Temp. Reg. G-5s; Supplement 1] Apsil 16, 1892.

Use of Contractor for Express Small Package Transportation

1. Purpose. This supplement extends the expiration date of FPMR Temporary Regulation G-54.

2 Effective date. This supplement is effective January 15, 1992.

3. Expination dale. This supplement expires November 15, 1992. unless sooner canceled or revised.

4. Bockground. FPMR Temporary Regulation G-54, dated Juły 9, 1991. prescribes policies and procedures applicable to Federal agencies when transportation of express amall packages from, to, and between specified locations in the United States (inctuding Alaska and Hawali) and Puerto Rico, is required and the contractor or its agent provides next day service. This regulation also identifies the contractor and the effective rates.

5. Explanation of change. The expiration date in paragraph 3 of FPMIR Temporary Regulation G-54 is extended to November 15. 1992.

Richard G. Austin,

Administrator of Ceneral Services.

[FR Doc 92-13747 Filed 6-12-82; 8:45 am] IUUNG COOE CBa-24-N



\section{DEPARTMENT OF THE INTERIOR}

\section{Bureau of Land Management}

43 CFR Public Land Order 6930

[NH-940-4214-10; NHNH 81795]

Withdrawal of Public Land for Wild Rivers Recreation Area; New Mexico

AGEHCY: Bureau of Land Menegement. Interior.

Actron: Public Land Order.

sumsaar: This order withdraws 4,979.94 acres of public land from surfece entry and minirs for a period of 20 years for the Bureau of Land Management to protect the Wild Rivers Recreation Area near the vicinity of Cerro, New Mexico. The land has been and remains open to mineral leasing.

EFFECTIVE DATE JUnE 15, 1992.

FOR FURTHER INFORMATION CONTACT:

Clarence F. Hougland, BLM New Mexico

State Office, P.O. Box 27115, Santa Fe,

New Mexico 87502-7115, 505-438-7593.
By virtue of the authority vested in the Secretary of the Interior by section 204 of the Federal.Land Policy and Management Act of 1976. 43 U.S.C. 1714 (1988), it is ordered as follows:

1. Subject to valid existing rights, the following described public land is hereby withdrawn from settlement, sale, location, or entry under the general land laws, including the United States mining laws (30 U.S.C. ch. 2 (1988)), but not . from leasing under the mineral leasing laws, to protect the Wild Rivers Recreation Area:

\section{Now Mexico Principal Meridien \\ T. 28 N. R. $12 \mathrm{E}$,}

Sec. 3. lots 1 to 4, inclusive, and SHN/2;

Sec. 4 lots 1 tọ 4, inclusive, S\%N3/, and S\%;

$\operatorname{Sec} 5$, lots 1 to 4 , inclusive, S\%2N $N{ }^{2} S W 1 / 4$, and $S E 1 / 4 ;$

Sec. 6, lot 1, and SEY/AEK/4;

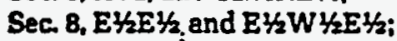

Sec. 9 , NWH/NE $1 / 4$, WHSWW/4NEY/, $W / 2 W y_{4}, W / 2 E / 2 S W / 4$, and NEYANE/4SWY;

Sec. 16, NWH/NWH/4;

Sec. 17. E/2NEY/4 and E/2W/2NEY/4.

T. 29 N. R. 12 E.

$\operatorname{Sec} 22, W \% S W \%$ and $W \% E \% S W / 4 ;$

Sec. 20, WHZWHEL/2 and $W / 2$;

$\operatorname{Sec} 28 ;$

Sec. 20, lots 1 to 8 , inclusive, EH/2E. - SEKSE $/ 4 N W \%, E 1 / 2 N E \% S W \%$, and SEYSWK4;

Sec. 31, SEY/SEY/;

Sec. 32, EY/2NWX/SWW/4;

Sec. 33;

Sec. 34, W1/2.

The area described contains 4,979.94 8cres in Teos County.

2. The withdrawal made by this order does not alter the applicability of those public land laws governing the use of the land under lease, license, or permit, or governing the disposal of its mineral or vegetetive resources other than under the mining laws.

3. This withdrawal will expire 20 years from the effective date of this order unless, as a result of a review conducted before the expiration date pursuant to section 204(f) of the Federal Land Policy and Management Act of 1976, 43 U.S.C. 1714(f) (1988), the

Secretary determines that the withdrawal shall be extended.

Dated: Junę 3, 1992.

Dave O'Neal,

Assistant Secretary of the Interios.

[FR Doc 92-13988 Filed 6-12-92; 8:45 8m]

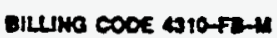

43 CFR Public Land Order 6931

$[C 0-930-4920-10-4329 ; \operatorname{coc}-53301]$

Transfer of Publle Land for the Gunnison Disposal Site; Colorado

AGEHCY: Bureau of Land Management. Interior.

Action: Public Land Order.

summany: This order permanently transfers 115 acres of public land to the Department of Energy in accordance with the terms of the Uranium Mill Tailings Remedial Action Amendments Act of 1988.

EFFECTVEE DATE JURE 15, 1992.

FOR FURTHER INFORMATION CONTACT:

Doris E. Chelius, BLM Colorado State

Office, 2850 Youngfield Street.

Lakewood, Colorado 80215-7076, 303239-1706.

By virtue of the authority vested in the Secretary of the Interior by the Uranium Mill Tailings Radiation Control Act of 1978 (42 U.S.C. 7916 (1988)), it is ordered as follows:

1. Subject to valid existing rights, the following described public land is hereby permanently transferred to the Department of Energy, and as a result of this transfer, the land is no longer subject to the operation of the general land laws, including the mining and mineral leasing laws, for the Gunnison Disposal Site:

Now Mexico Principal Moridian

T. 49 N. R. 1 E.

Sec. 15, S1/2SW/4NEY/4E1/4, S1/2S1/2N

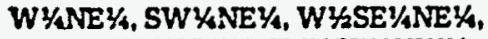
SHSEE $1 / 4 N E 1 / 4 N W 1 / 4, N E 1 / 4$ SE $/ 4 N W 1 / 4$, N/2SEYSE/4NW\%, SEY/SE1/4S

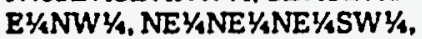
$N / 2 N W / N E K S E 1 / 4$, and $N / 2 N / 2 N$ WHSEY4.

The area described contains approximately 115 acres of public land in Gunnison County.

2. The transfer of the above-described land to the Department of Energy vests in that Department the full management jurisdiction, responsibility, and liability for such land and all activities conducted thereon, except as provided in paragraph 3.

3. The Secretary of the Interior shall retain the authority to administer any existing claims, rights, and interests in this land established before the effective date of the transfer.

Deted: June 3, 1992.

Dave ONeal,

Assistant Secretary of the Isterior. [FR Doc 92-13885 Filed 6-12-92; 8:45 am] HUUNO CODE 4910-1B-X 


\section{ATTACHMENT 2}

\section{AGENCY NOTIFICATION AGREEMENTS}


Department of Energy

Albuquerque Operations Office

P. O. Box 5400

Albuquerque, New Mexico 87185-5400

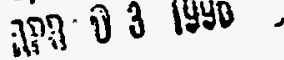

Rick Murdie

Gunnison County Sheriff's Office

200 E. Virgina Avenue

Gunnison, Colorado 81230

Dear Sheriff Murdie:

The U.S. Department of Energy (DOE) Uranium Mill Tailings Remedial Action Project is requesting notification in the event of any unusual activities or events in southeast Gunnison County, Colorado, around the DOE's Gunnison uranium mill tailings disposal site. The site is located approximately six miles southeast of Gunnison, Colorado, in Township 49 North, Range 1 East, Section 15, just southwest the Gunnison County Landfill. The disposal site is reached by taking County Road 42 (Sixmile Lane) south from U.S. Highway 50 to BLM Route 3068 then proceeding west about one mile (see enclosed map).

The purpose of the notification request is to assist the DOE in monitoring and maintaining the integrity of the Gunnison disposal site and to ensure public safety.

If during the course of routine activities, anything out of the ordinary that could potentially impact the site is observed by your staff or reported to your office, we would appreciate notification to the DOE Grand Junction Projects Office's 24-hour phone line at (970) 2486070.

If the notification request discussed above is agreeable to you, please sign and return the attached reply letter for our records as soon as possible.

Should you have any questions, please contact me at (505) $845-4865$. Thank you for your attention in this matter.

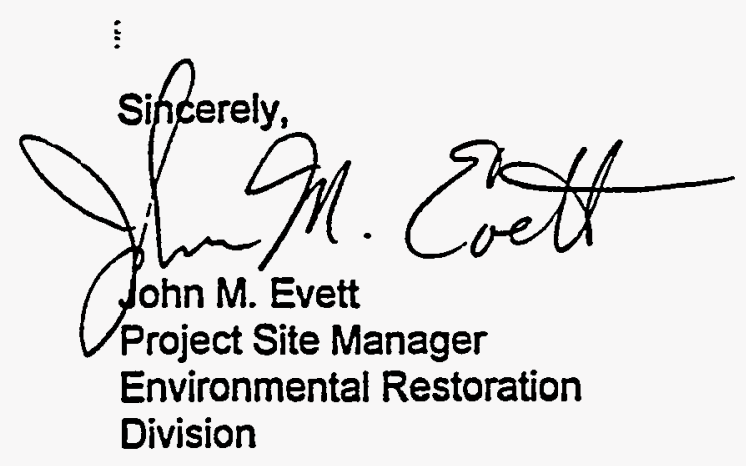

\section{Enclosures}

cc w/o enclosures:

J. Virgona, GJPO 
John M. Evett

Project Site Manager

Environmental Restoration Division

U.S. Department of Energy

P.O. Box 5400

Albuquerque, NM 87115

Dear Mr. Evett:

This letter is to concur with the U.S. Department of Energy (DOE) request for notification as set forth in the DOE's letter. As requested in your letter, this office will contact the DOE's Grand Junction Projects Office at (970) 248-6070 if any unusual event or anomaly is observed or reported at or around the DOE's Gunnison disposal site, Gunnison County, Colorado.

Sincerely,

Rick Murdie

Gunnison County Sheriff

cc: J. Virgona, GJPO 
Larry Mooney

Area Manager

National Weather Service Office

10230 Smith Road

Denver, Colorado 80239

Dear Mr. Mooney:

The U.S. Department of Energy (DOE) Uranium Mill Tailings Remedial Action Project is requesting notification in the event of issuance of flash flood or tornado wamings in southeast Gunnison County, Colorado. We would appreciate notification to the DOE Grand Junction Projects Office's 24-hour phone line at (970) 248-6070 within 8 hours of issuance of a warning or episode of warnings.

The purpose of this warning is to assist the DOE in monitoring and maintaining the integrity of its Gunnison uranium mill tailings disposal site located about six miles southeast of Gunnison, Colorado, about two miles southwest of the junction of U.S. Highway 50 and County Road 42 (see enclosed map).

If the notification request discussed above is agreeable to you, please sign and retum the enclosed reply letter for our records as soon as possible.

Should you have any questions, please contact me at (505) 845-4865.

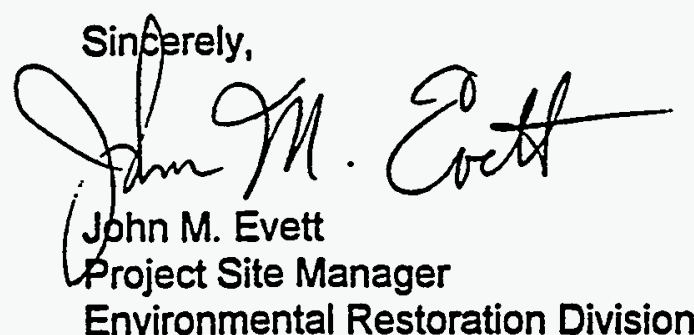

Enclosures

cc w/o enclosures:

J. Virgona, GJPO 
John M. Evett

Project Site Mariager

Environmental Restoration Division

U.S. Department of Energy

P.O. Box 5400

Albuquerque, NM 87115

Dear Mr. Evett:

1

This letter is to concur with the U.S. Department of Energy (DOE) request for notification as set forth in the DOE's letter. As requested in your letter, this office will contact the DOE's Grand Junction Projects Office at (970) 248-6070 if any unusual event or anomaly is observed or reported at or around the DOE's Gunnison disposal site, Gunnison County, Colorado.

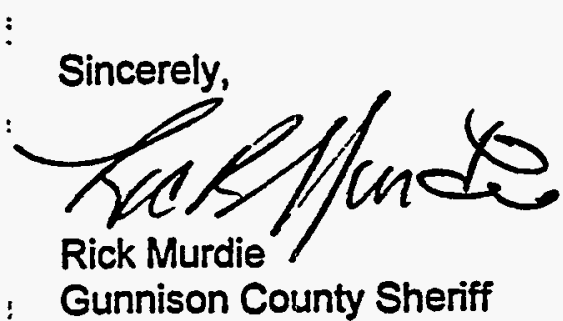

cc: J. Virgona, GJPO 
Director

(303) 236-1510

Research

(303) 236-1506
C.S. Geological Survey

Box 25046, DFC. MS-96t

Dequer. Colorado 80205 LSA

Telex: (WL'TCO) 5106014123ESL LD
Operations

(303) 236-7500

QED

(800) $358-2663$

Clinton C. Smythe

Engineering and Construction Group Leader

Uranium Mill Tailings Remedial Action

Project Office

2155 Louisiana NE, Suite 4,000

Albuquerque, NM 87110

Dear ivr. Smythe:

This letter is to confirm that the DOE Grand Junction Projects Office (24-hour phone line, (303) 248-6070 has been added to our notification list for the occurrence of earhquakes near the following locations:

\begin{tabular}{|c|c|c|}
\hline Disposal Site & Latitude & Longitude \\
\hline \multicolumn{3}{|l|}{ COLORADO } \\
\hline Durango (Bodo Canyon) & N37.15 & W107.90 \\
\hline Grand Junction & N38.91 & W108.32 \\
\hline Gunnison (Landtill) & N38.51 & W106.85 \\
\hline Maybell & N40.55 & W107.99 \\
\hline Naturita (Dry Flats) & $\sqrt{38.21}$ & W108.60 \\
\hline Rifle (Estes Gulch) & N39.60 & W107.82 \\
\hline Slick Rock (Burto Canyon) & N38.05 & W108.87 \\
\hline \multicolumn{3}{|l|}{ IDAHO } \\
\hline Lowman & N44.16 & W115.61 \\
\hline \multicolumn{3}{|l|}{ NEW MEXICO } \\
\hline Ambrosia Lake & $\overline{\mathrm{N} 35.41}$ & W107.80 \\
\hline \multicolumn{3}{|l|}{ NORTH DAKOTA } \\
\hline Bowman & $\overline{N 46.23}$ & W103.55 \\
\hline \multicolumn{3}{|l|}{ OREGON } \\
\hline Lakeview (Collins Ranch) & N42.2 & W120.3 \\
\hline \multicolumn{3}{|l|}{ PENNSYLVANIA } \\
\hline Canonsburg & N40.26 & W80.25 \\
\hline Burrell VP & N40.62 & W79.65 \\
\hline \multicolumn{3}{|l|}{ TEXAS } \\
\hline Falls City & N28.91 & W98.13 \\
\hline \multicolumn{3}{|l|}{ UTAH } \\
\hline Mexican Hat & N37.10 & W109.85 \\
\hline Salt Lake City (Clive) & N40.69 & W113.1I \\
\hline
\end{tabular}


National Earthquake Information Center. World Data Center A for Seismology

Director

(303) 236-1510

Research

(303) 236-1506
U.S. Geological Survey

Box 25046, DFC, MS -967

Denver, Colorado 80225 USA

Telex: (WUTCO) 5106014123ESL ID
Operations

(303) 236-1500

QED

(800) 358-2663.

Clinton C. Smythe

$-2-$

We have entered the following selection criteria into our notification program:

1. Any earthquake of magnitude 3.0 or greater, within 0.3 degrees (about 20 miles) of any site shown above, or

2. Any earthquake of magnitude 5.0 or greater, within 1.0 degrees (about 70 miles) of any site shown above. .

Sincerely,

Trace is. Preageave

Bocce Presgrave

U.S. Geological Survey

National Earthquake Information Center

P.O. Box 25046

Mail Stop 967

Denver Federal Center

Denver, Colorado 80225

Please address future comespondonce to stuart Koyanagi at the above address. I have moved to a different project.

Thank you + best regards,

Ene Prengrave

A2-6 